Prepared in cooperation with the Bureau of Reclamation and the U.S. Fish and Wildlife Service

\title{
A Natural History Summary and Survey Protocol for the Southwestern Willow Flycatcher
}

Chapter 10 of

Section A, Biological Science

Book 2, Collection of Environmental Data

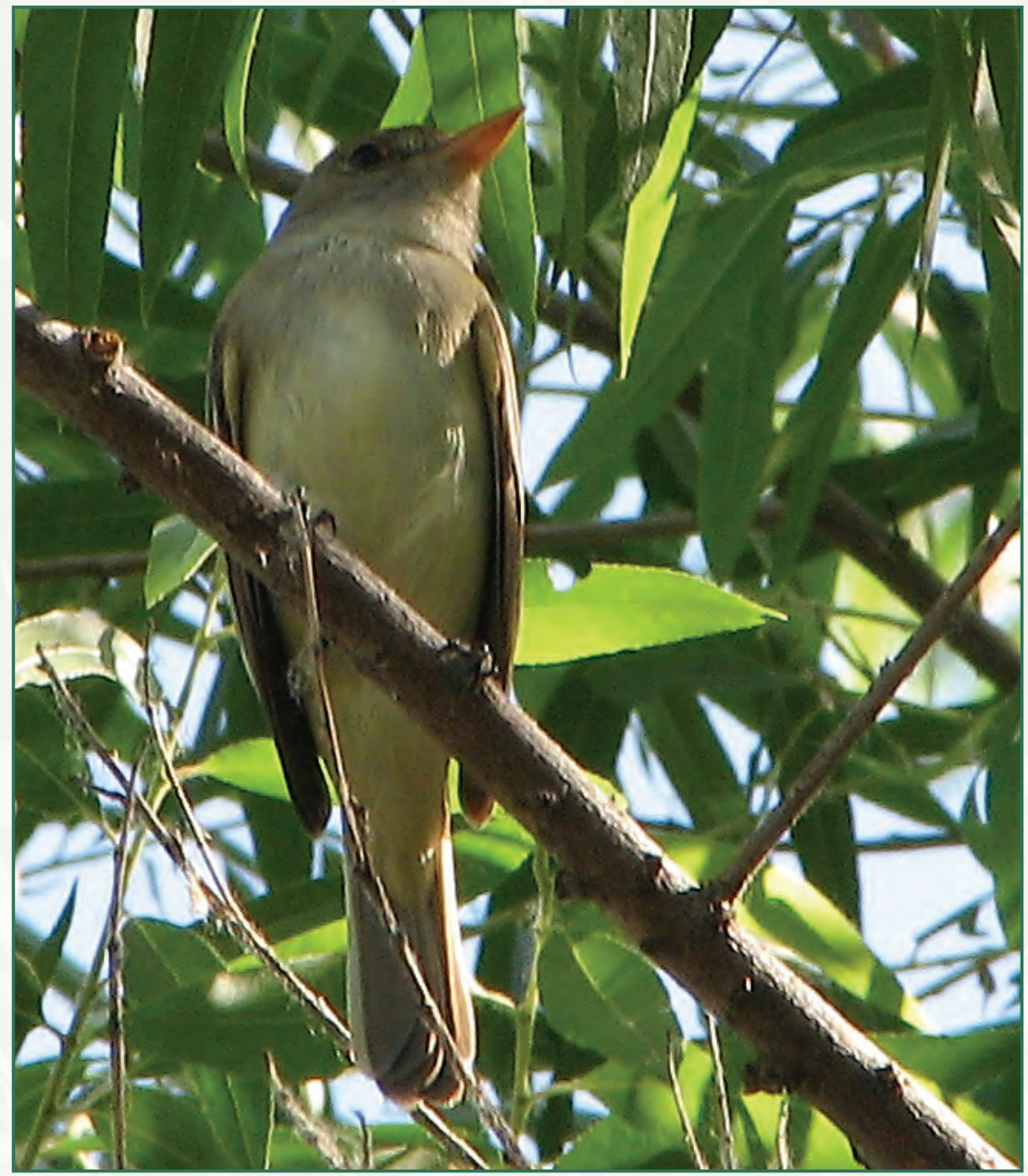

Techniques and Methods 2A-10 
Cover: Southwestern Willow Flycatcher. Photograph taken by Susan Sferra, U.S. Fish and Wildlife Service. 


\section{A Natural History Summary and Survey Protocol for the Southwestern Willow Flycatcher}

By Mark K. Sogge, U.S. Geological Survey; Darrell Ahlers, Bureau of Reclamation; and Susan J. Sferra, U.S. Fish and Wildlife Service

Chapter 10 of

Section A, Biological Science

Book 2, Collection of Environmental Data

Prepared in cooperation with the Bureau of Reclamation and the U.S. Fish and Wildlife Service

Techniques and Methods 2A-10 


\title{
U.S. Department of the Interior \\ KEN SALAZAR, Secretary
}

\section{U.S. Geological Survey \\ Marcia K. McNutt, Director}

\section{U.S. Geological Survey, Reston, Virginia: 2010}

\author{
For more information on the USGS — the Federal source for science about the Earth, its natural and living resources, \\ natural hazards, and the environment, visit http://www.usgs.gov or call 1-888-ASK-USGS \\ For an overview of USGS information products, including maps, imagery, and publications, \\ visit http://www.usgs.gov/pubprod \\ To order this and other USGS information products, visit http://store.usgs.gov
}

\begin{abstract}
Any use of trade, product, or firm names is for descriptive purposes only and does not imply endorsement by the U.S. Government.

Although this report is in the public domain, permission must be secured from the individual copyright owners to reproduce any copyrighted materials contained within this report.
\end{abstract}

Suggested citation:

Sogge, M.K., Ahlers, Darrell, and Sferra, S.J., 2010, A natural history summary and survey protocol for the southwestern willow flycatcher: U.S. Geological Survey Techniques and Methods 2A-10, 38 p. 


\section{Contents}

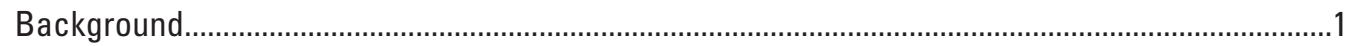

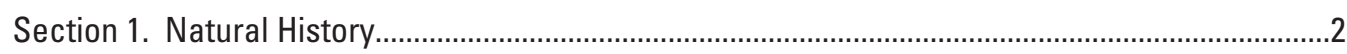

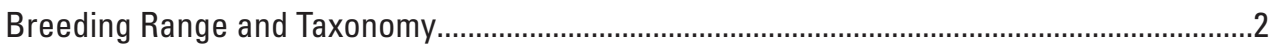

Migration and Winter Range, Habitat, and Ecology ................................................................2

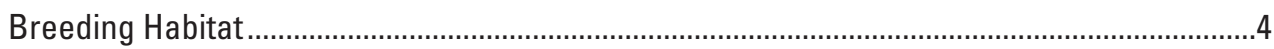

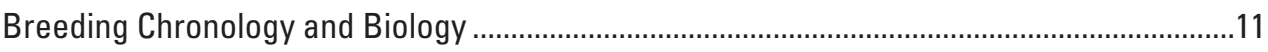

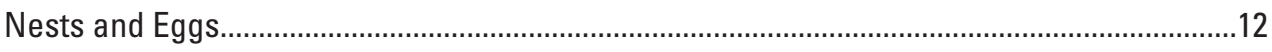

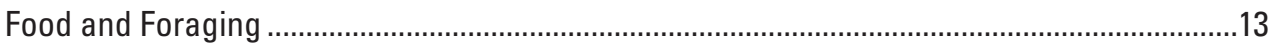

Site Fidelity and Survivorship ..........................................................................................

Threats to the Flycatcher and Habitat................................................................................ 14

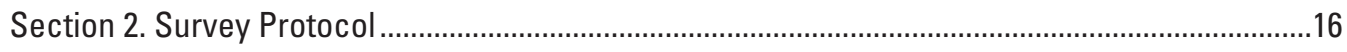

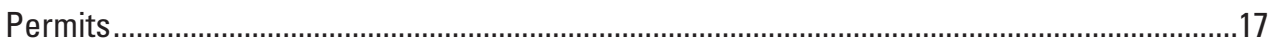

Pre-Survey Preparation .......................................................................................................

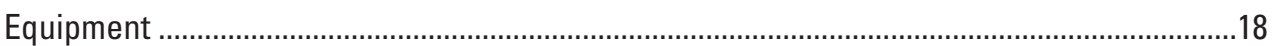

Willow Flycatcher Identification .......................................................................................... 19

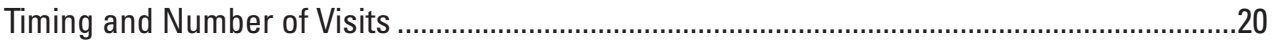

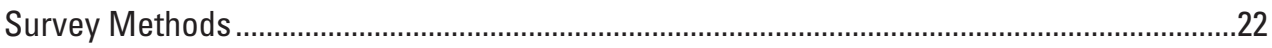

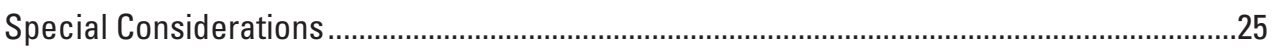

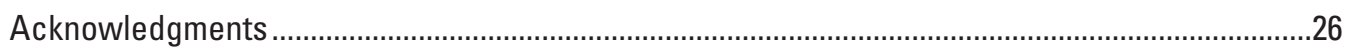

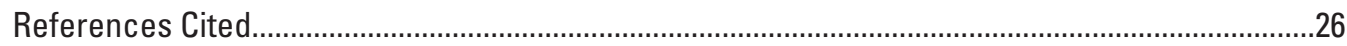

Appendix 1. Willow Flycatcher Survey and Detection Form .........................................................31

Appendix 2. Willow Flycatcher Survey Continuation Sheet / Territory Summary Table .................33

Appendix 3. Instructions for Completing the Willow Flycatcher Survey and Detection Form and the Survey Continuation Sheet .................................................................34

Appendix 4. Example of a Completed Willow Flycatcher Survey and

Detection Form (with map) 


\section{Figures}

Figure 1. Map showing approximate ranges of the Willow Flycatcher (Empidonax traillii) during breeding and non-breeding seasons

Figure 2. Photographs showing examples of Southwestern Willow Flycatcher breeding habitat in native broadleaf vegetation at high-elevation sites

Figure 3. Photographs showing examples of Southwestern Willow Flycatcher breeding habitat in native broadleaf vegetation at low and mid-elevation sites

Figure 4. Photographs showing examples of Southwestern Willow Flycatcher breeding habitat in exotic vegetation

Figure 5. Photographs showing examples of Southwestern Willow Flycatcher breeding habitat in mixed native/exotic vegetation

Figure 6. Photographs showing examples of dense vegetation structure within breeding habitats of Southwestern Willow Flycatcher

Figure 7. Photographs showing examples of the variable hydrologic conditions at breeding habitats of Southwestern Willow Flycatcher

Figure 8. Diagram showing generalized migration and breeding chronology for the Willow Flycatcher in the Southwest

Figure 9. Diagram showing recommended numbers and timing of visits during each survey period for general surveys and project surveys.

\section{Conversion Factors}

\begin{tabular}{lll}
\hline \multicolumn{1}{c}{ Multiply } & \multicolumn{1}{c}{ By } & \multicolumn{1}{c}{ To obtain } \\
\hline centimeter $(\mathrm{cm})$ & 0.3937 & inch (in.) \\
gram (g) & 0.03527 & ounce, avoirdupois (oz) \\
hectare (ha) & 2.471 & acre \\
kilometer $(\mathrm{km})$ & 0.6214 & mile (mi) \\
meter (m) & 3.281 & foot (ft) \\
millimeter (mm) & 0.03937 & inch (in.) \\
\hline
\end{tabular}

\section{Abbreviations and Acronyms}

GPS

NDVI

USFWS

USGS
Global Positioning System

Normalized Difference Vegetation Index

U.S. Fish and Wildlife Service

U.S. Geological Survey 


\title{
A Natural History Summary and Survey Protocol for the Southwestern Willow Flycatcher
}

\author{
By Mark K. Sogge, U.S. Geological Survey; Darrell Ahlers, Bureau of Reclamation; and \\ Susan J. Sferra, U.S. Fish and Wildlife Service
}

\section{Background}

The Southwestern Willow Flycatcher (Empidonax traillii extimus) has been the subject of substantial research, monitoring, and management activity since it was listed as an endangered species in 1995. When proposed for listing in 1993, relatively little was known about the flycatcher's natural history, and there were only 30 known breeding sites supporting an estimated 111 territories rangewide (Sogge and others, 2003a). Since that time, thousands of presence/absences surveys have been conducted throughout the historical range of the flycatcher, and many studies of its natural history and ecology have been completed. As a result, the ecology of the flycatcher is much better understood than it was just over a decade ago. In addition, we have learned that the current status of the flycatcher is better than originally thought: as of 2007 , the population was estimated at approximately 1,300 territories distributed among approximately 280 breeding sites (Durst and others, 2008a).

Concern about the Southwestern Willow Flycatcher on a rangewide scale was brought to focus by Unitt (1987), who described declines in flycatcher abundance and distribution throughout the Southwest. E. t. extimus populations declined during the 20th century, primarily because of habitat loss and modification from activities, such as dam construction and operation, groundwater pumping, water diversions, and flood control. In 1991, the U.S. Fish and Wildlife Service (USFWS) designated the Southwestern Willow Flycatcher as a candidate category 1 species (U.S. Fish and Wildlife Service, 1991). In July 1993, the USFWS proposed to list E. t. extimus as an endangered species and to designate critical habitat under the Act (U.S. Fish and Wildlife Service, 1993). A final rule listing E. t. extimus as endangered was published in February 1995 (U.S. Fish and Wildlife Service, 1995); critical habitat was designated in 1997 (U.S. Fish and Wildlife Service, 1997). The USFWS Service released a Recovery Plan for the Southwestern Willow Flycatcher in 2002 (U.S. Fish and Wildlife Service, 2002), and re-designated critical habitat in 2005 (U.S. Fish and Wildlife Service, 2005).
In addition to its federal status, the Southwestern Willow Flycatcher is listed as an endangered species or species of concern in Arizona (Arizona Game and Fish Department, 2006), New Mexico (New Mexico Department of Game and Fish, 1996), California (California Department of Fish and Game, 1991), and Utah (Utah Division of Wildlife Resources, 1997).

Sound management and conservation of an endangered species like the Southwestern Willow Flycatcher requires current, detailed information on its abundance and distribution. This requires, among other things, identifying where flycatchers are and are not breeding, and annual monitoring of as many breeding areas as possible. Such efforts require effective, standardized survey protocols and consistent reporting, at both local and regional levels. However, the Willow Flycatcher is a difficult species to identify and survey for. Moreover, inconsistent or ineffective surveys are of limited value, can produce misleading information (including "false positives" and "false negatives"), hinder regional and rangewide analyses, and waste limited resources.

We developed this document to provide a standardized survey protocol and a source of basic ecological and status information on the flycatcher. The first section summarizes the current state of knowledge regarding Southwestern Willow Flycatcher natural history, based on a wide array of published and unpublished literature. Emphasis is given to information relevant to flycatcher conservation and management, and to conducting and interpreting surveys. The second section details a standard survey protocol that provides for consistent data collection, reporting, and interpretation. This protocol document builds on and supersedes previous versions, the most recent of which was Sogge and others (1997a). In this update, we incorporate over a decade of new science and survey results, and refine the survey methodology to clarify key points. Further, we update the standard survey data sheets and provide guidelines on how to fill in the requested information. Amidst these revisions, the basic approach of the survey protocol has remained unchanged-multiple surveys at each survey area within the same breeding season, the use of the call-playback technique using flycatcher vocalizations to increase the probability of detection, and verification of species identity through its diagnostic song. 


\section{Section 1. Natural History}

\section{Breeding Range and Taxonomy}

The Willow Flycatcher is a widespread species that breeds across much of the conterminous United States (Sedgwick, 2000). Four subspecies commonly are recognized in North America, with each occupying a distinct breeding range (fig. 1): E. t. adastus, ranging across the northern Rocky Mountains and Great Basin; E. t. brewsteri, found west of the Sierra Nevada and Cascade Mountains along the Pacific Slope; E. t. extimus, the Southwestern Willow Flycatcher, which breeds across the Southwest; and E. t. traillii, ranging east of the northern Rocky Mountains. Although the overall subspecies' ranges are distinct, Sedgwick (2001) and Paxton (2008) noted interbreeding/gradation zones in the boundary area between E. t. extimus and E. t. adastus.

The breeding range of the Southwestern Willow Flycatcher includes southern California, Arizona, New Mexico, southwestern Colorado, and extreme southern portions of Nevada and Utah: specific range boundaries are delineated in the subspecies' recovery plan (U.S. Fish and Wildlife Service, 2002). Unitt (1987) included western Texas in the subspecies' range, but recent breeding records from western Texas are lacking. Records of probable breeding Southwestern Willow Flycatchers in Mexico are few and restricted to extreme northern Baja California and Sonora (Unitt, 1987; Wilbur, 1987). Although recent data are lacking, the USFWS does include parts of northern Mexico in its description of E. t. extimus breeding range (U.S. Fish and Wildlife Service, 2002).

Although they appear very similar to most observers, experienced taxonomist or those using specialized equipment (for example, an electronic colorimeter) can differentiate among the subspecies by subtle differences in color and morphology (for example, Unitt, 1987; Paxton, 2008). Despite the subtle level of differences, the taxonomic status of E. t. extimus has been critically reviewed and confirmed multiple times based on morphological, genetic, and song data (Hubbard, 1987; Unitt, 1987; Browning, 1993; Paxton, 2000; Sedgwick, 2001).

The Southwestern Willow Flycatcher was described by Phillips (1948) from a specimen collected along the San Pedro River in southeastern Arizona. The Southwestern Willow Flycatcher generally is paler than other Willow Flycatcher subspecies, although this difference is indistinguishable without considerable experience and training, and study skins as comparative reference material. The southwestern subspecies differs in morphology (primarily wing formula) but not overall size. The plumage and color differences between the Willow Flycatcher subspecies are so subtle that they should not be used to characterize birds observed in the field (Unitt, 1987; Hubbard, 1999; U.S. Fish and Wildlife Service, 2002).

\section{Migration and Winter Range, Habitat, and Ecology}

All Willow Flycatcher subspecies breed in North America but winter in the subtropical and tropical regions of southern Mexico, Central America, and northern South America (Sedgwick, 2000; Koronkiewicz, 2002; fig. 1). Most wintering birds are found in the Pacific slope lowlands in Mexico and Central America, and Caribbean slope lowlands in Mexico and Guatemala.

Because all Willow Flycatcher subspecies look very similar, determining specific wintering sites for the southwestern race has been challenging. However, recent genetic analysis of wintering birds (Paxton, 2008) suggests that the four subspecies occupy finite areas of the wintering grounds, but with overlapping ranges. The Southwestern Willow Flycatcher appears to be largely restricted to the center of the winter range (in the vicinity of Costa Rica), although Paxton (2008) suggests more research is needed to address this question.

On the wintering grounds, flycatchers primarily are found in habitats that have four main components: (1) standing or slow moving water and/or saturated soils, (2) patches or stringers of trees, (3) woody shrubs, and (4) open areas (Koronkiewicz and Whitfield, 1999; Koronkiewicz and Sogge, 2000; Lynn and others, 2003; Nishida and Whitfield, 2007; Schuetz and others, 2007). Based on surveys to date, the presence of water or saturated soils is almost universal, although tree heights and configurations, the presence of woody shrubs, and the amount of open space surrounding winter territories can vary considerably (Schuetz and others, 2007).

Male and female flycatchers hold separate, individual non-breeding territories, and defend those territories throughout the winter by using song, calls, and aggression displays. Fidelity to wintering territories and sites is high, as is survivorship over the wintering period (Koronkiewicz and others, 2006b; Sogge and others, 2007).

Willow Flycatchers travel approximately 1,500-8,000 km each way between wintering and breeding areas. During migration, flycatchers use a wider array of forest and shrub habitats than they do for breeding, although riparian vegetation may still be a preferred migration habitat type (Finch and others, 2000). Migration requires high energy expenditures, exposure to predators, and successful foraging in unfamiliar areas. Therefore, migration is the period of highest mortality within the annual cycle of the flycatcher (Paxton and others, 2007). Willow Flycatchers of all subspecies sing during northward migration, perhaps to establish temporary territories for short-term defense of food resources. 


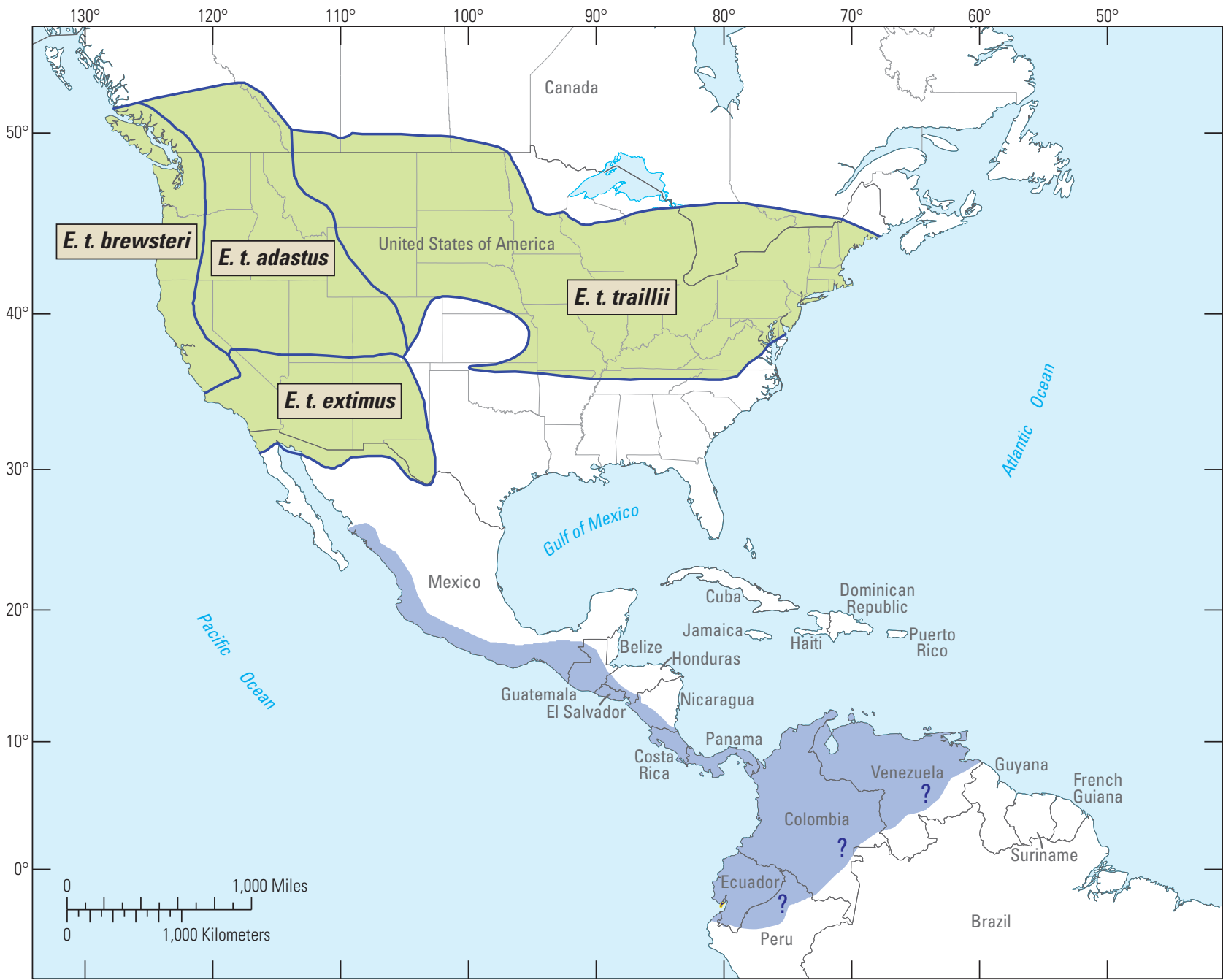

Basemap modified from U.S. Geological Survey and other agency digital data, various scales. Projection Mercator, World Geodetic System1984 datum.

\section{EXPLANATION}

Approximate range distribution of the Willow Flycatcher (Empidonax traillii)—Adapted from Unitt (1987), Browning (1993), and Paxton (2008)

Breeding range, including boundaries of the Willow Flycatcher subspecies

? Wintering range-Question marks reflect uncertainty of the location of the eastern boundary of the winter range

Figure 1. Approximate ranges of the Willow Flycatcher (Empidonax traillii) during breeding and non-breeding seasons. 
Southwestern Willow Flycatchers typically arrive on breeding grounds between early May and early June (Ellis and others, 2008; Moore and Ahlers, 2009). Because arrival dates vary annually and geographically, northbound migrant Willow Flycatchers of multiple subspecies pass through areas where Southwestern Willow Flycatchers have already begun nesting. Similarly, southbound migrants in late July and August may occur where Southwestern Willow Flycatchers are still breeding (Unitt, 1987). This can make it challenging for an observer to differentiate local breeders from migrants. Other than timing, we still know relatively little about Southwestern Willow Flycatcher migratory behavior, pathways, or habitat use.

\section{Breeding Habitat}

Breeding Southwestern Willow Flycatchers are riparian obligates, typically nesting in relatively dense riparian vegetation where surface water is present or soil moisture is high enough to maintain the appropriate vegetation characteristics (Sogge and Marshall, 2000; U.S. Fish and Wildlife Service, 2002; Ahlers and Moore, 2009). However, hydrological conditions in the Southwest can be highly variable within a season and between years, so water availability at a site may range from flooded to dry over the course of a breeding season or from year to year.

The Southwestern Willow Flycatcher breeds in dense riparian habitats across a wide elevational range, from near sea level in California to more than 2,600 $\mathrm{m}$ in Arizona and southwestern Colorado (Durst and others, 2008a). Vegetation characteristics of Southwestern Willow Flycatcher breeding habitat generally include dense tree or shrub cover that is $\geq 3 \mathrm{~m}$ tall (with or without a higher overstory layer), dense twig structure, and high levels of live green foliage (Allison and others, 2003); many patches with tall canopy vegetation also include dense midstory vegetation in the 2-5 m range. Beyond these generalities, the flycatcher shows adaptability in habitat selection, as demonstrated by variability in dominant plant species (both native and exotic), size and shape of breeding patch, and canopy height and structure (U.S. Fish and Wildlife Service, 2002).

Southwestern Willow Flycatcher breeding habitat can be quantified and characterized in a number of ways, depending on the level of detail needed and habitat traits of interest. For many sites, detailed floristic composition, plant structure, patch size, and even characteristics such as Normalized Difference Vegetation Index (NDVI) have been described in agency reports and scientific journal articles (Allison and others, 2003; Hatten and Paradzick, 2003; Koronkiewicz and others, 2006a; Hatten and Sogge, 2007; Moore, 2007; Schuetz and Whitfield, 2007; Ellis and others, 2008). For purposes of this survey protocol, we take a relatively simple approach and broadly describe and classify breeding sites based on plant species composition and habitat structure. Clearly, these are not the only important components, but they are conspicuous to human perception and easily observed and recorded. Thus, they have proven useful in conceptualizing, selecting and evaluating suitable survey habitat, and in predicting where breeding flycatchers are likely to be found.

Breeding habitat types commonly used by Southwestern Willow Flycatchers are described below. The general categories are based on the composition of the tree/shrub vegetation at the site-native broadleaf, exotic, and mixed native/exotic. In the field, breeding habitats occur along a continuum of plant species composition (from nearly monotypic to mixed species) and vegetation structure (from simple, single stratum patches to complex, multiple strata patches). The images in figures 2-7 illustrate some of the variation in flycatcher breeding habitat, and other examples can be found in numerous publications and agency reports, and on the USGS photo gallery web site (http://sbsc.wr.usgs. gov/SBSCgallery/). The intent of the descriptions and photographs is to provide a general guide for identifying suitable habitat in which to conduct surveys.

Native broadleaf.-Southwestern Willow Flycatchers breed across a great elevational range, and the characteristics of their native broadleaf breeding sites varies between high elevation sites and those at low and mid-elevation sites.

High elevation sites (fig. 2) range from nearly monotypic dense stands of willow to mixed stands of native broadleaf trees and shrubs, 2-7 $\mathrm{m}$ in height with no distinct overstory layer; often associated with sedges, rushes, nettles, and other herbaceous wetland plants; usually very dense structure in lower $2 \mathrm{~m}$; live foliage density is high from the ground to the canopy. Vegetation surrounding the patch can range from open meadow, to agricultural lands, to pines or upland shrub.

At low and mid-elevations (fig. 3), flycatcher breeding sites can be composed of single species (often Goodding's willow (Salix gooddingii), S. exigua, or other willow species) or mixtures of native broadleaf trees and shrubs including (but not limited to) cottonwood, willows, boxelder (Acer negundo), ash (Fraxinus spp.), alder (Alnus spp.), and buttonbush (Cephalanthus spp.), height from 3 to $15 \mathrm{~m}$; characterized by trees of different size classes; often a distinct overstory of cottonwood, willow or other broadleaf tree, with recognizable subcanopy layers and a dense understory of mixed species; exotic/introduced species may be a rare component, particularly in the understory.

Monotypic exotic.-(fig. 4) Breeding sites also can include nearly monotypic, dense stands of exotics such as saltcedar (Tamarix spp.) or Russian olive (Elaeagnus angustifolia), 4-10 $\mathrm{m}$ in height forming a nearly continuous, closed canopy (with no distinct overstory layer); lower $2 \mathrm{~m}$ commonly very difficult to penetrate due to dense branches, however, live foliage density may be relatively low 1-2 m above ground, but increases higher in the canopy; canopy density uniformly high. 


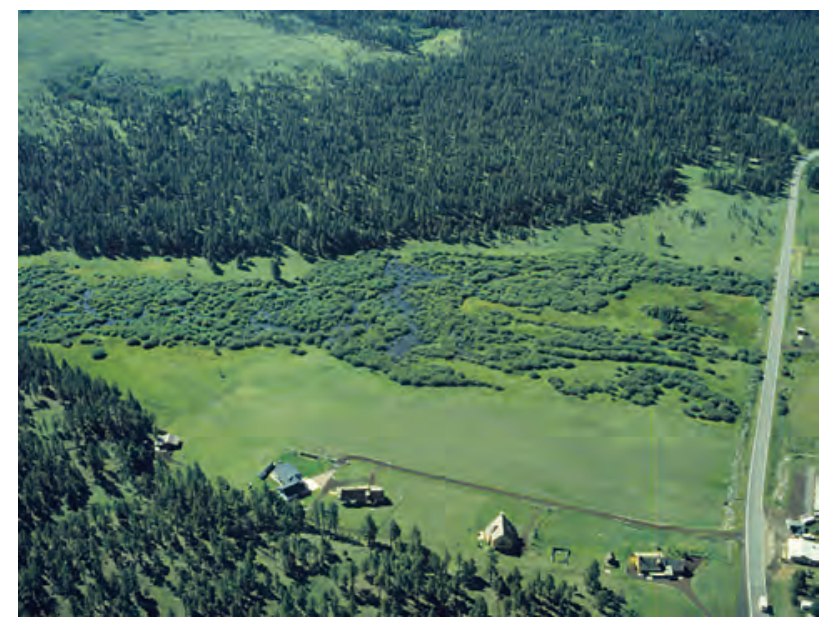

Aerial view of Little Colorado River near Greer, Arizona. Photograph by USGS, 1995 .

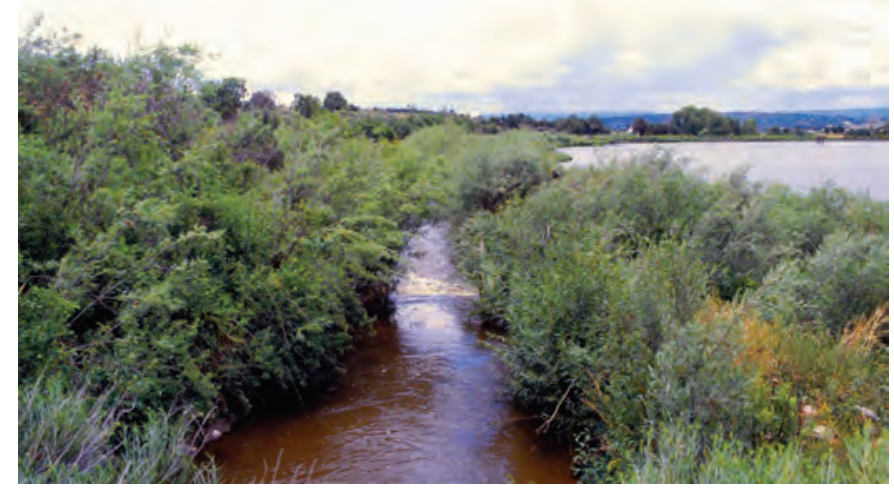

Parkview Fish Hatchery, New Mexico. Photograph by USGS, 2000.

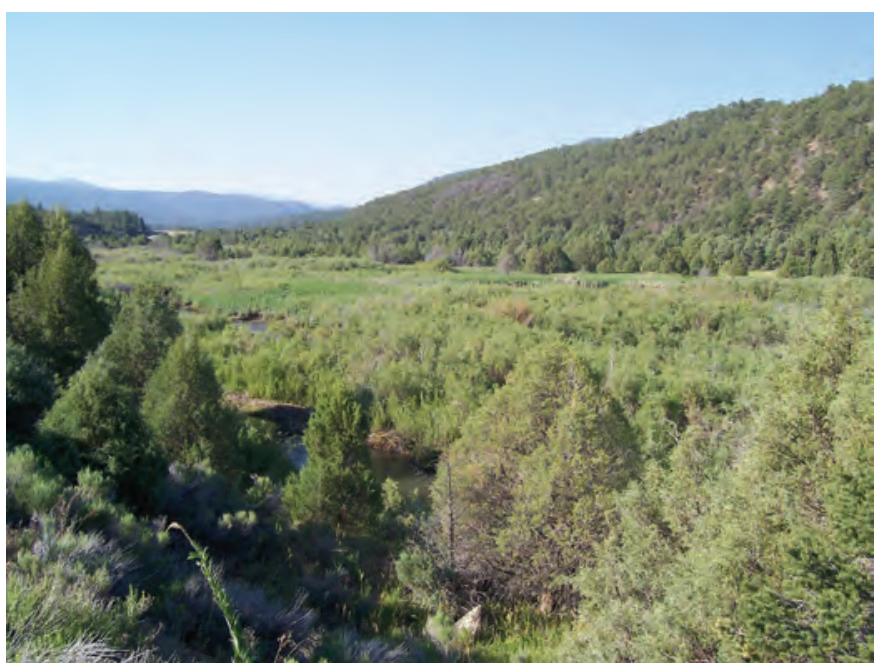

Tierra Azul, New Mexico. Photograph by USGS, 2005.

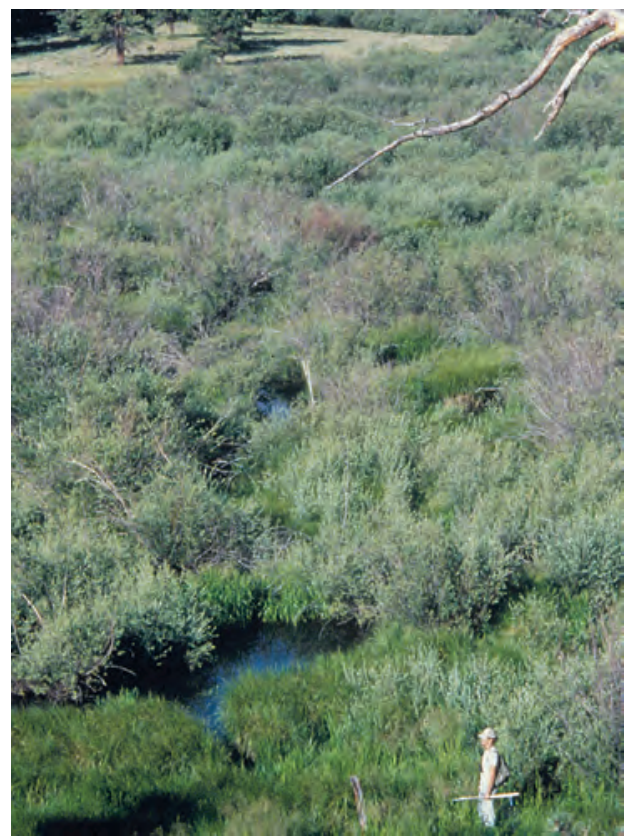

Little Colorado River near Greer, Arizona. Photograph courtesy of Arizona Game and Fish Department, 1996.

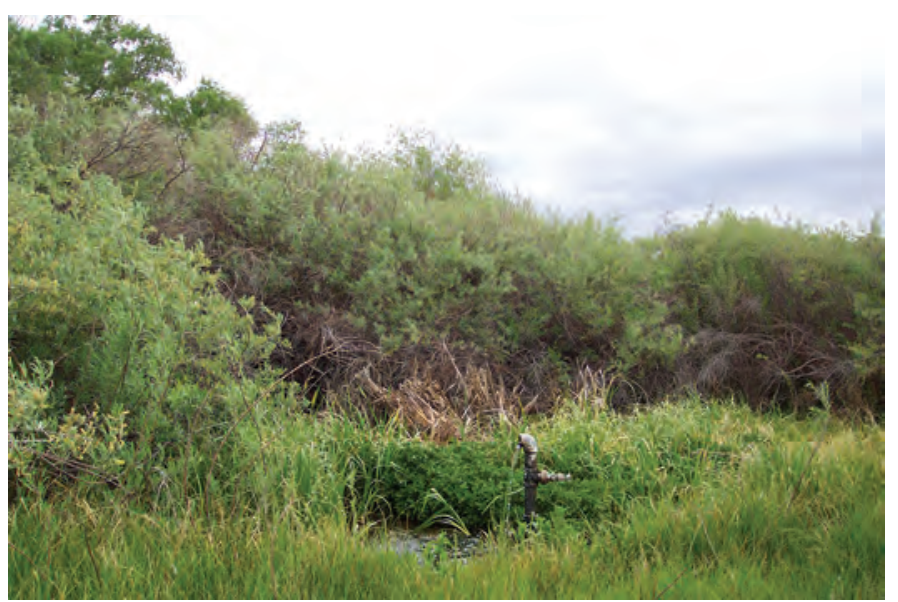

Rio Grande State Wildlife Area, Colorado. Photograph by USGS, 2002.

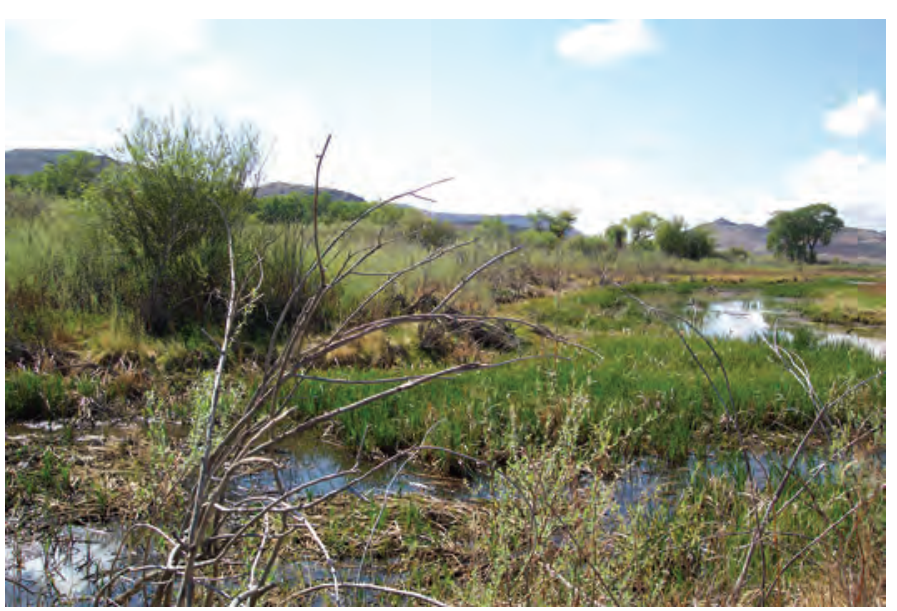

McIntyre Springs, Colorado. Photograph by USGS, 2002.

Figure 2. Examples of Southwestern Willow Flycatcher breeding habitat in native broadleaf vegetation at high-elevation sites. 


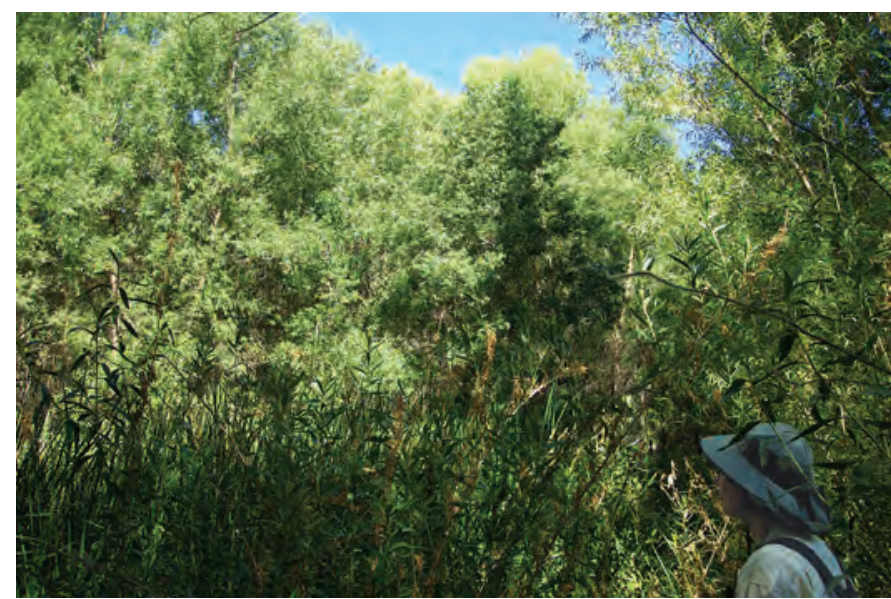

Hassayampa River, Arizona. Photograph by USGS, 2003.

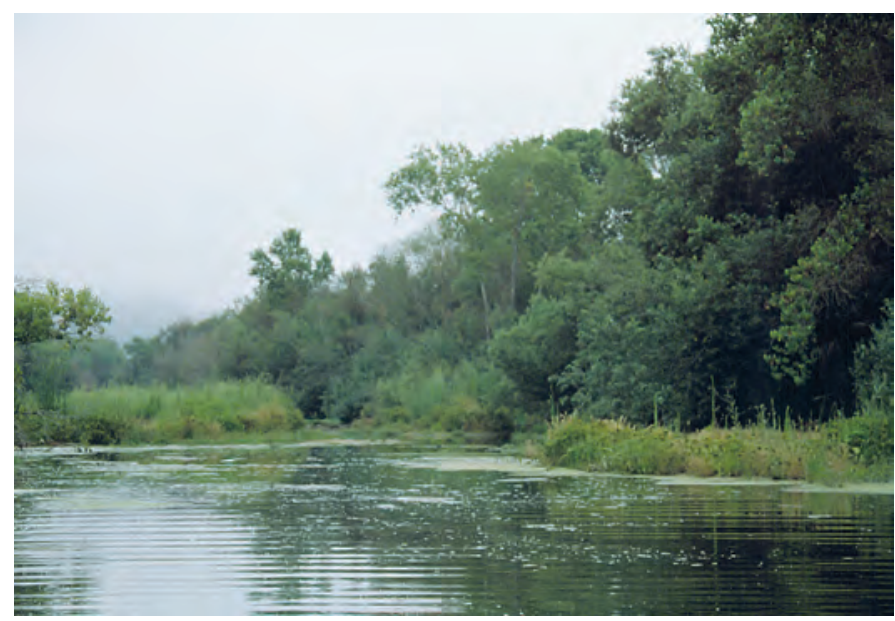

Santa Ynez River, California, Photograph by USGS, 1996.

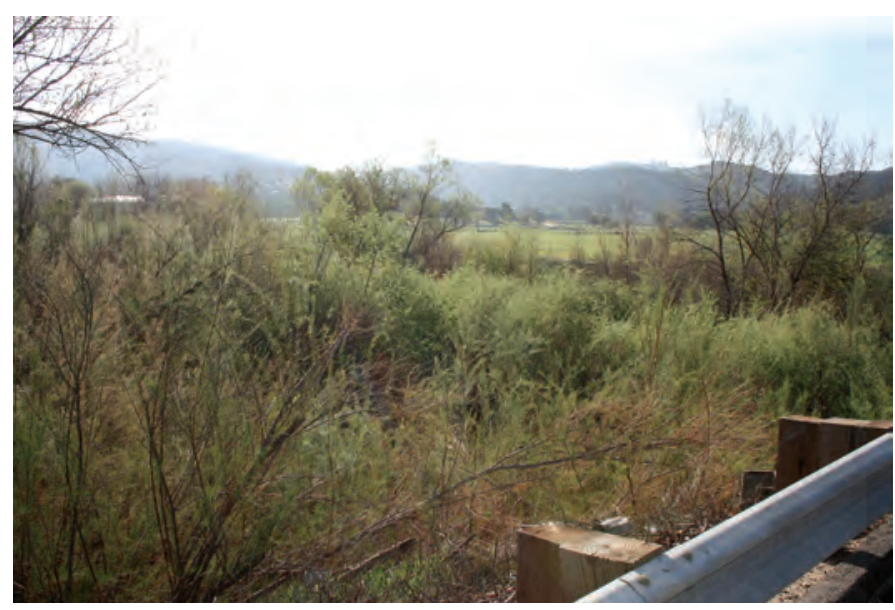

San Luis Rey River, California. Photograph by USGS, 2005.

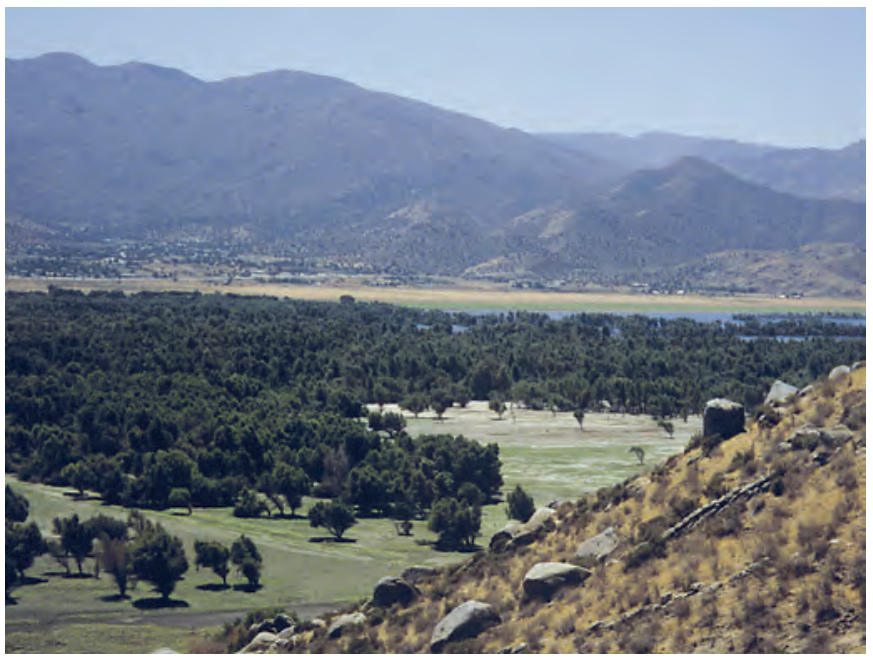

Kern River, California. Photograph by USGS, 1995.

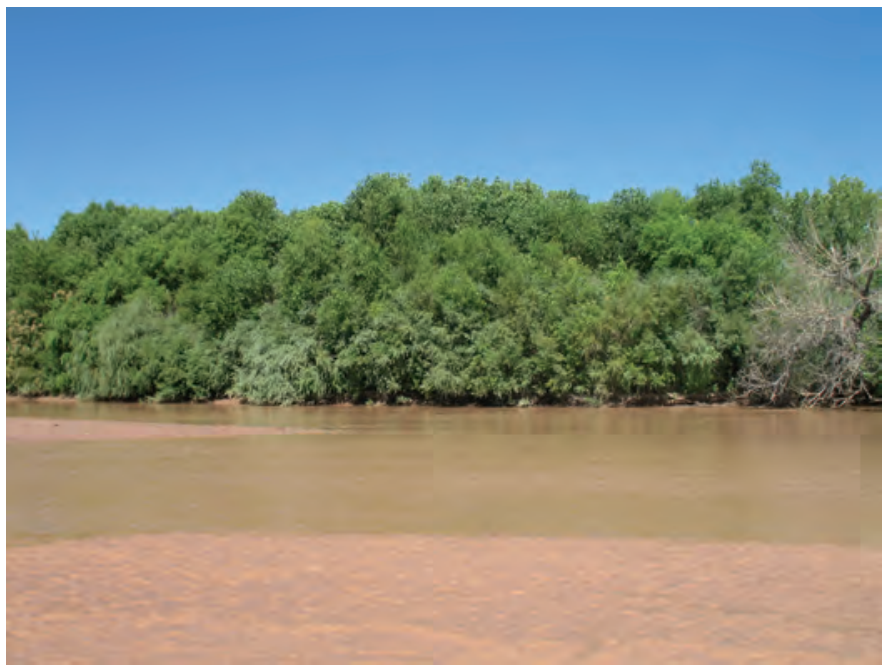

Bosque del Apache, Rio Grande, New Mexico. Photograph courtesy of Bureau of Reclamation, 2008.

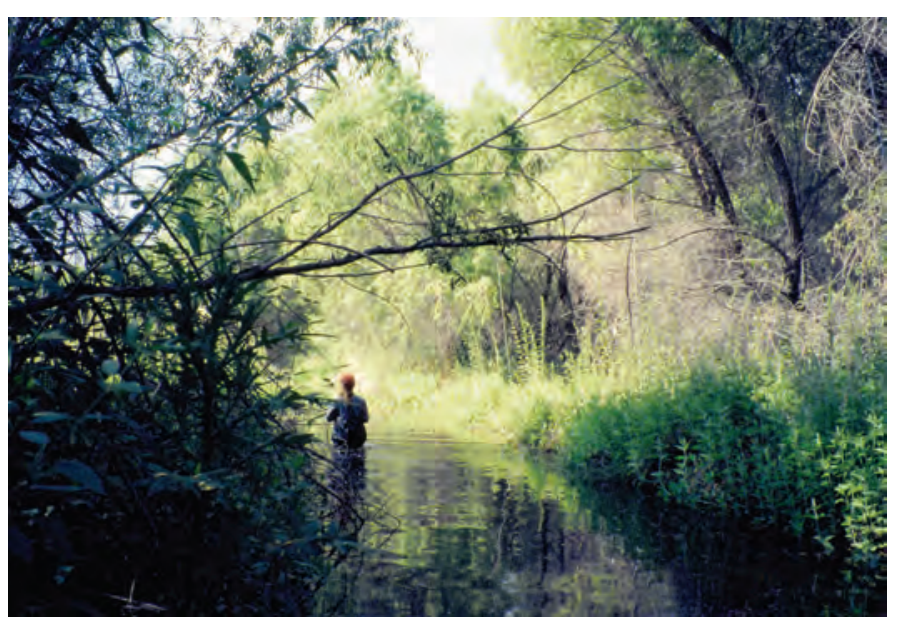

Kern River, California. Photograph by USGS, 1995.

Figure 3. Examples of Southwestern Willow Flycatcher breeding habitat in native broadleaf vegetation at low and mid-elevation sites. 


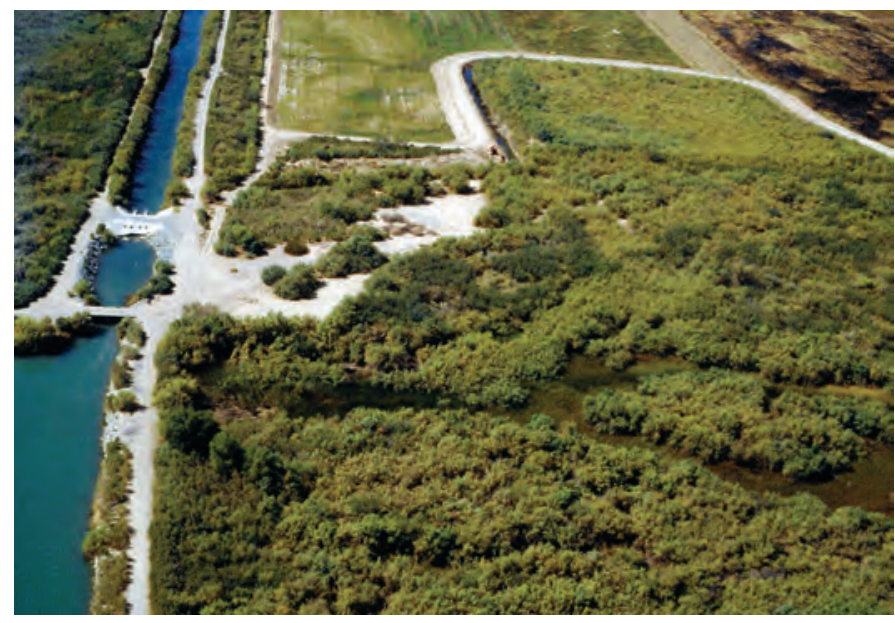

Aerial view of Topock Marsh, Colorado River, Arizona. Photograph by USGS, 1996.

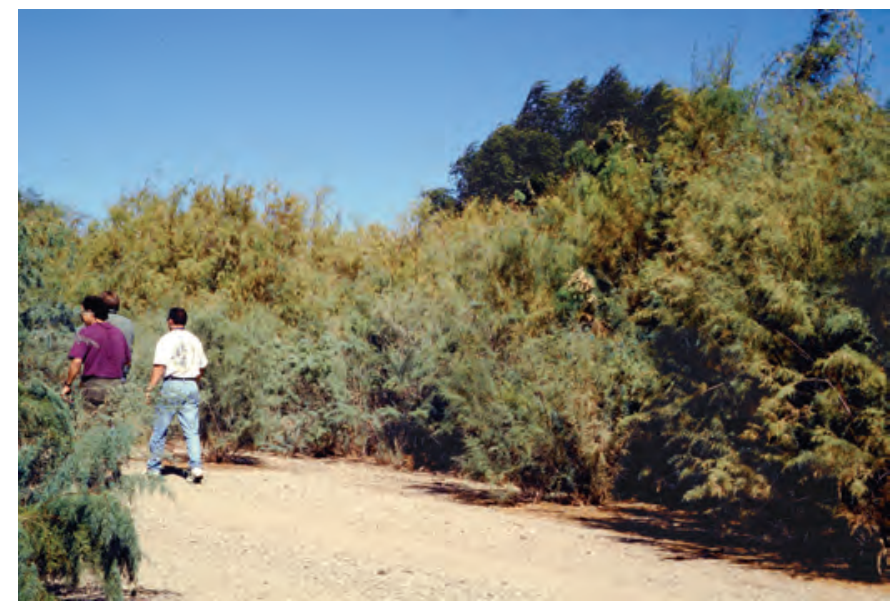

Topock Marsh, Colorado River, Arizona. Photograph by USGS, 1996.

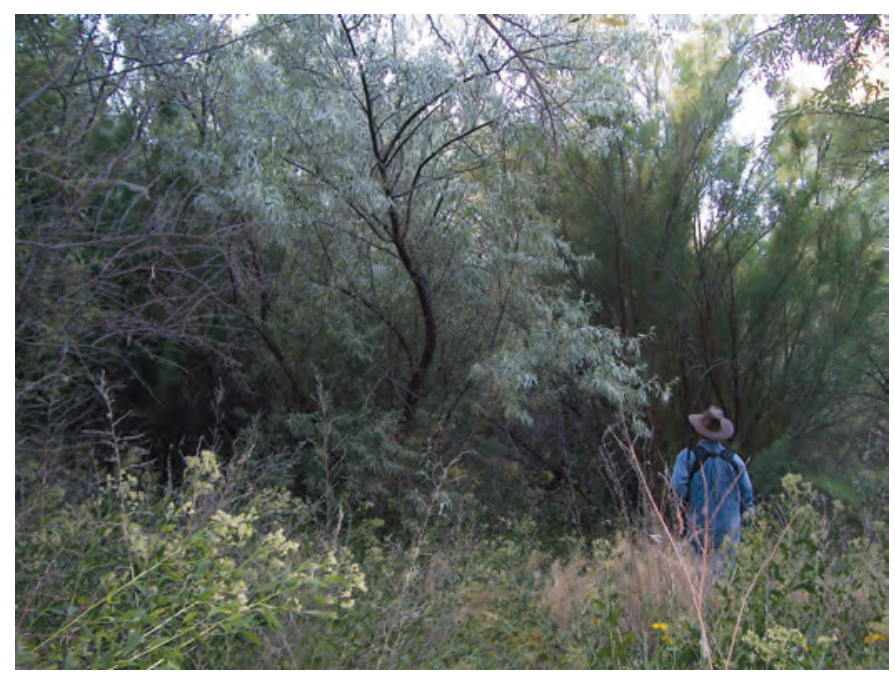

Rio Grande, New Mexico. Photograph by USGS, 2005.

Figure 4. Examples of Southwestern Willow Flycatcher breeding habitat in exotic vegetation.

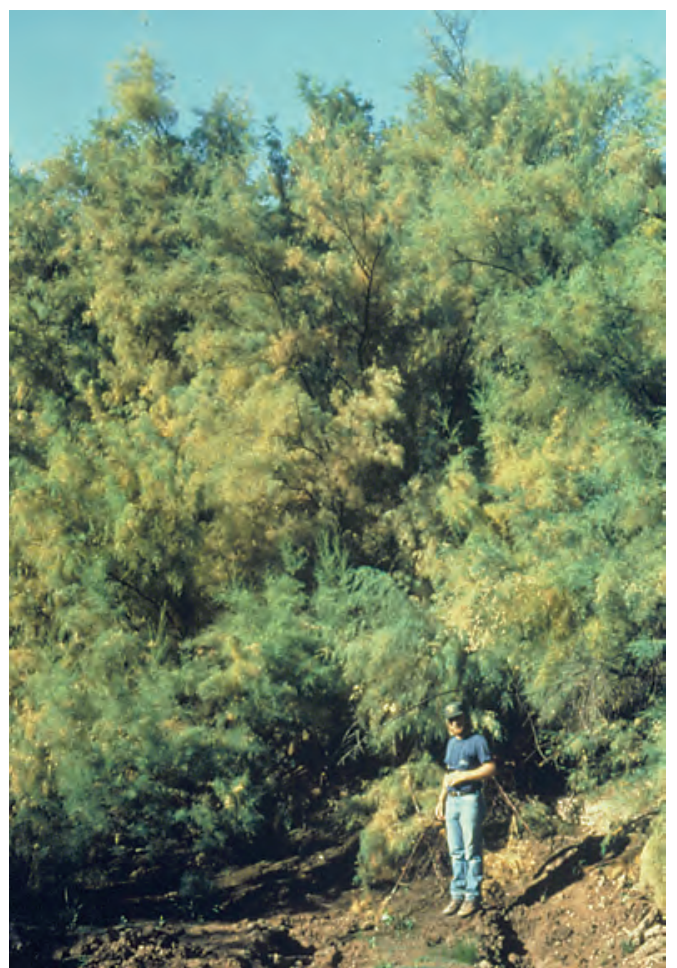

Salt River, Arizona. Photograph courtesy of Bureau of Reclamation, 1996.

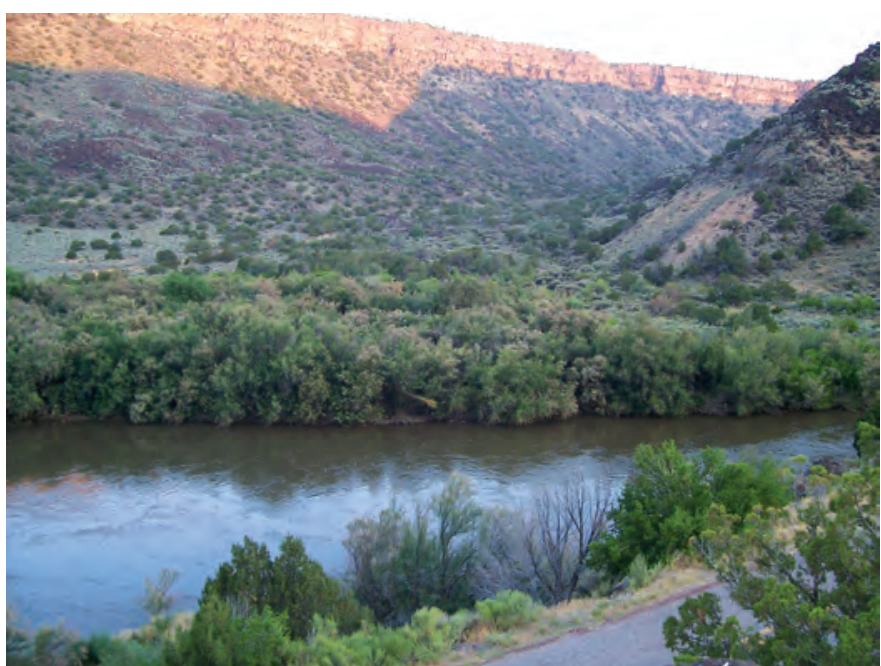

Orrilla Verde, Rio Grande, New Mexico. Photograph by USGS, 2006.

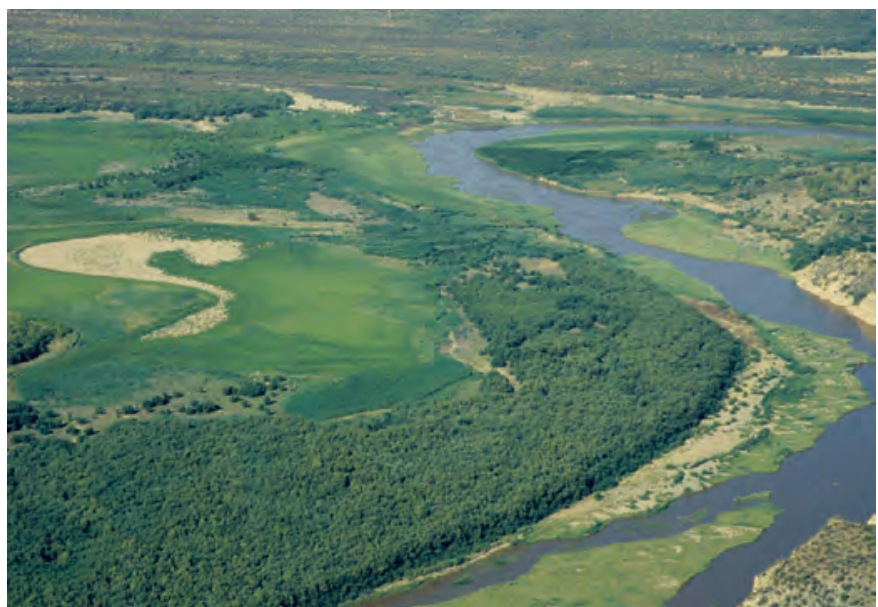

Aerial view of Salt River, Arizona. Photograph by USGS, 1996. 
Mixed native/exotic-(fig. 5) These sites include dense mixtures of native broadleaf trees and shrubs (such as those listed above) mixed with exotic/introduced species, such as saltcedar or Russian olive; exotics are often primarily in the understory, but may be a component of overstory; the native and exotic components may be dispersed throughout the habitat or concentrated as a distinct patch within a larger matrix of habitat; overall, a particular site may be dominated primarily by natives or exotics, or be a more-or-less equal mixture.

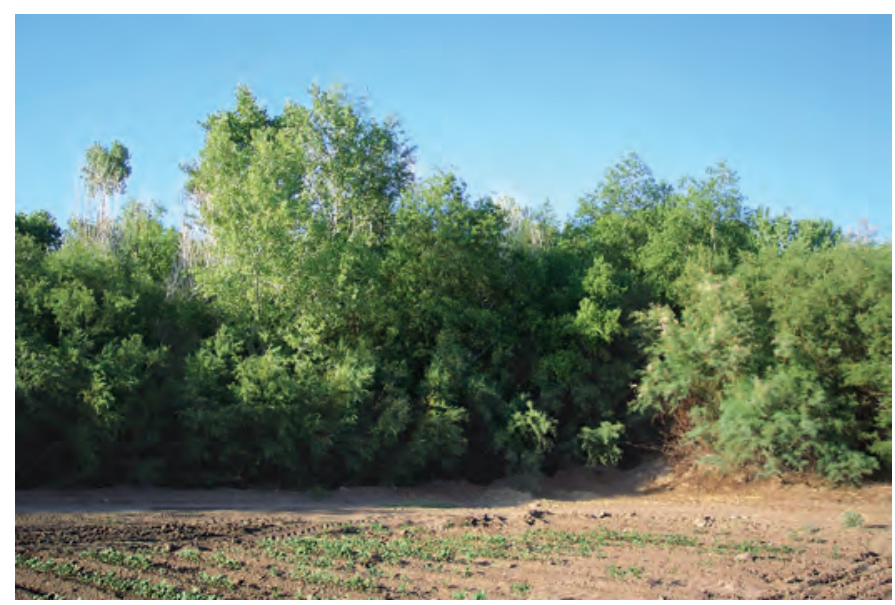

Gila River, Arizona. Photograph by USGS, 2002.

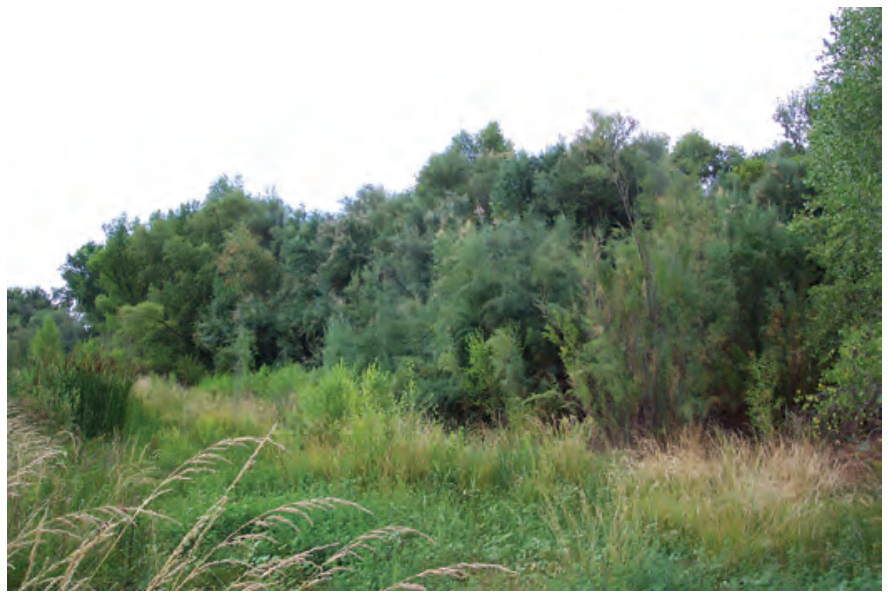

Verde River River, Arizona. Photograph by USGS, 2002.
Regardless of the plant species composition or height, occupied sites almost always have dense vegetation in the patch interior (fig. 6). These dense patches are often interspersed with small openings, open water, or shorter/ sparser vegetation, creating a mosaic that is not uniformly dense.

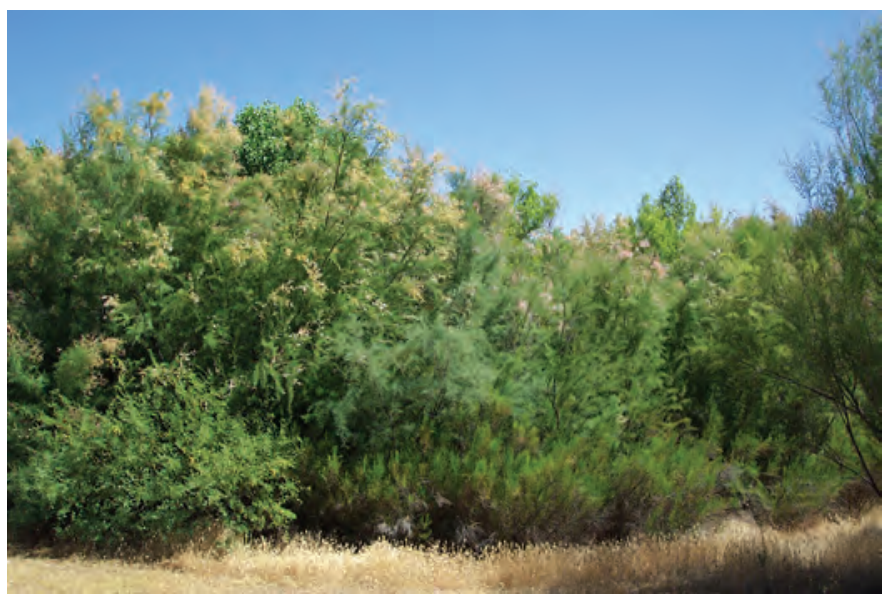

Roosevelt Lake, Arizona. Photograph by USGS, 1999.

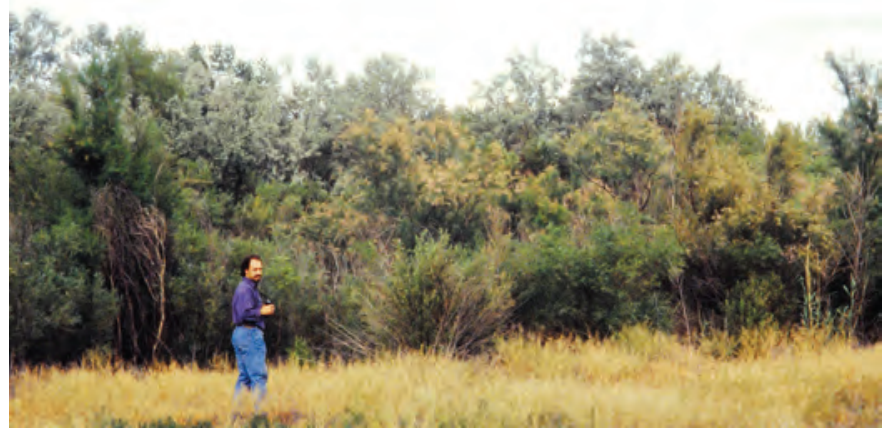

Virgin River, Utah. Photograph by USGS, 1997.

Figure 5. Examples of Southwestern Willow Flycatcher breeding habitat in mixed native/exotic vegetation. 


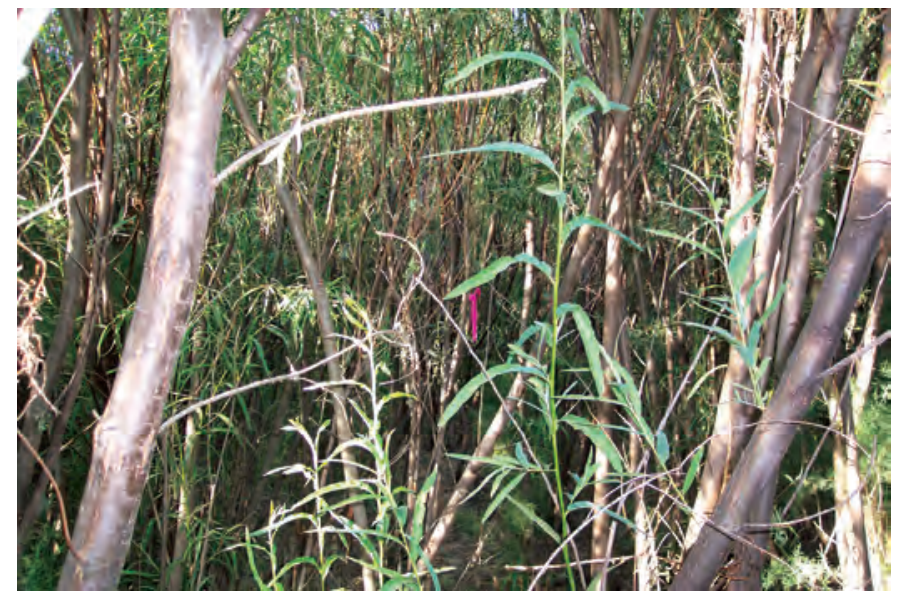

Gila River, Arizona. Photograph by USGS, 2002.

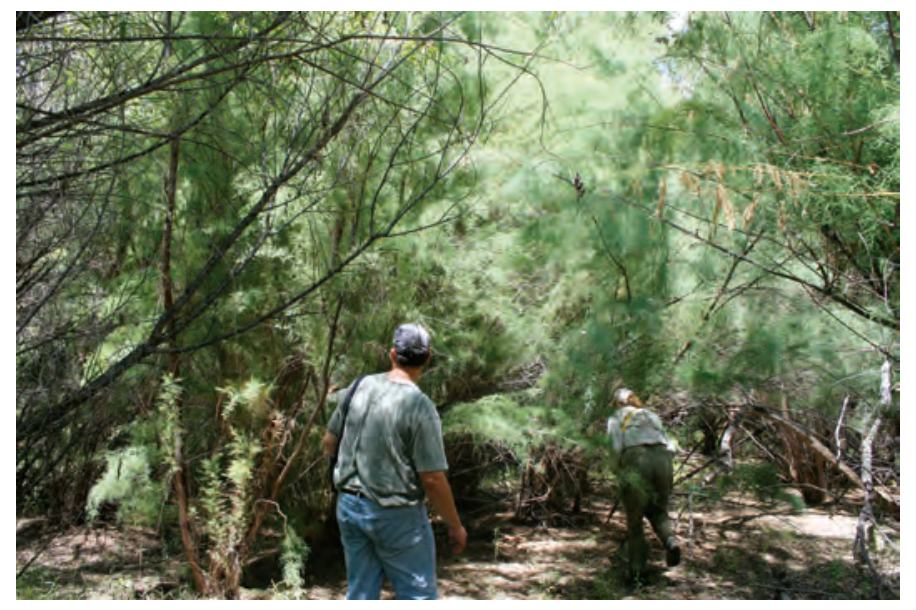

Rio Grande, New Mexico. Photograph by USGS, 2007.

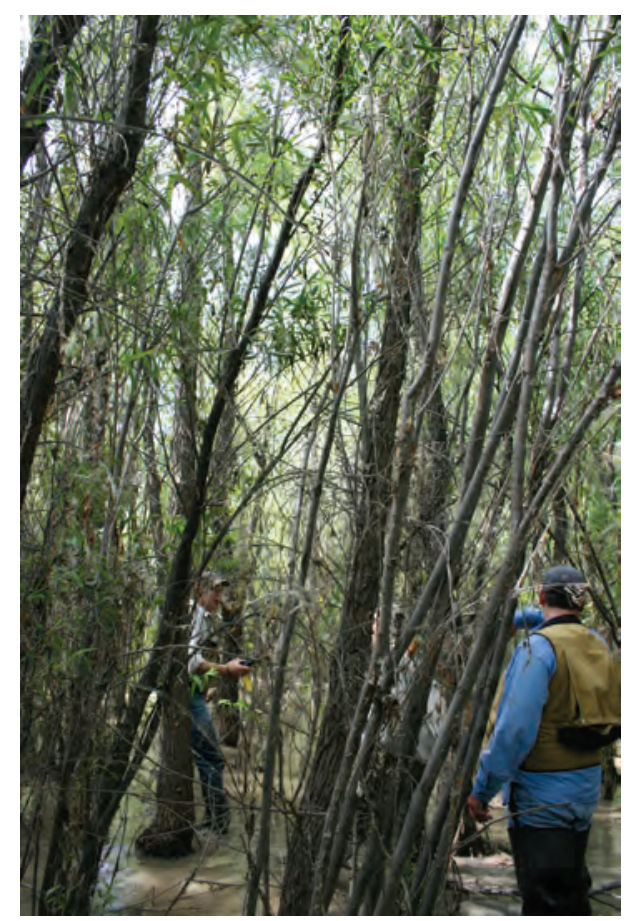

Rio Grande, New Mexico. Photograph by USGS, 2007.

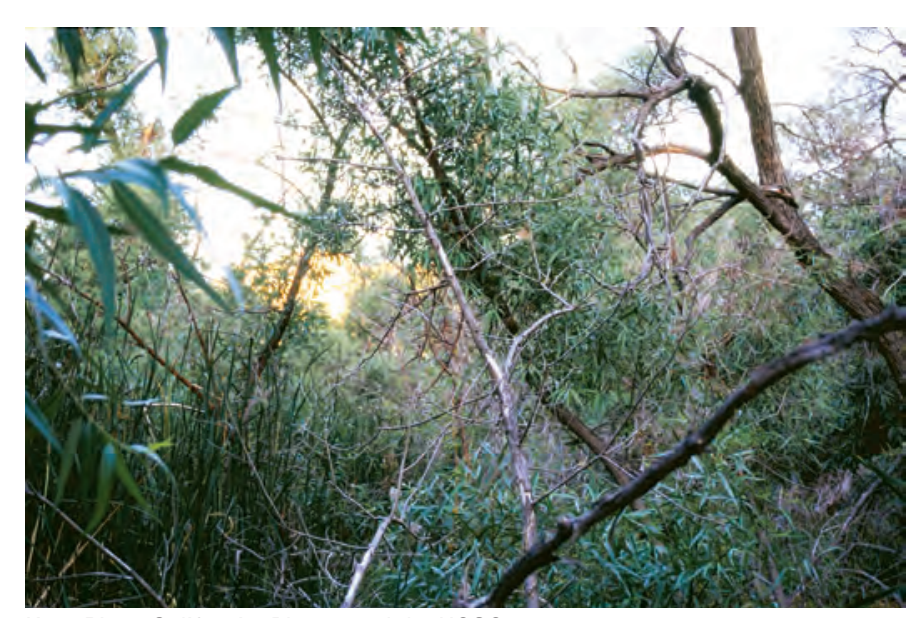

Kern River, California. Photograph by USGS, 1999.

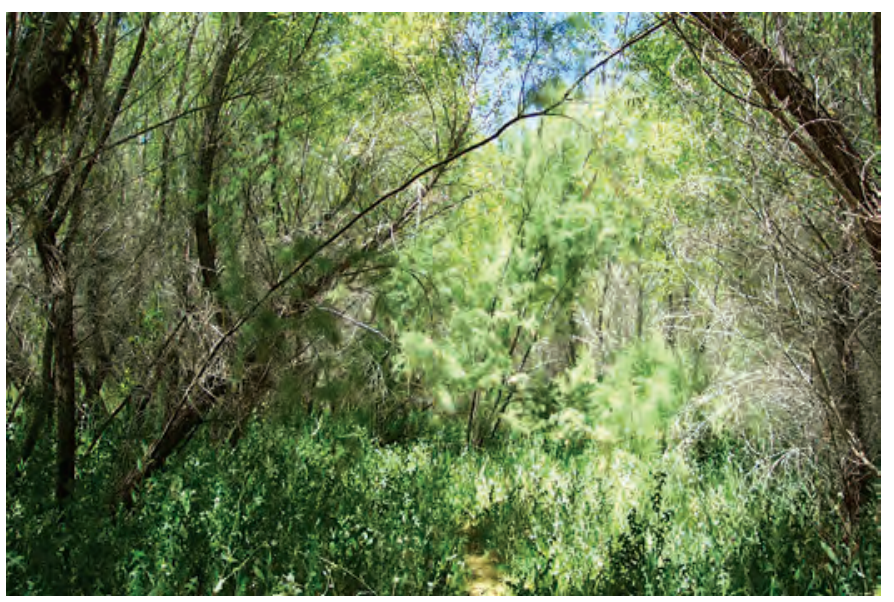

Salt River, Arizona. Photograph by USGS, 1999.

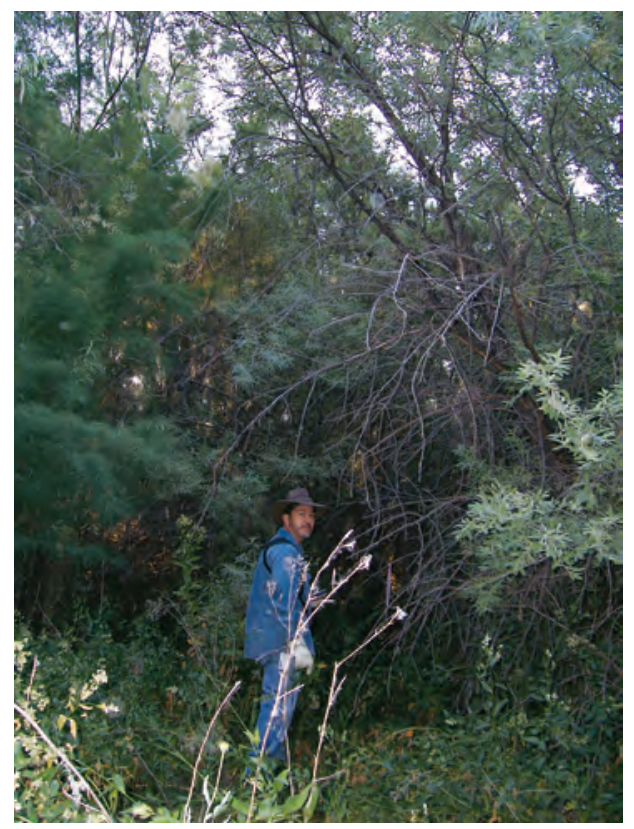

Rio Grande, New Mexico. Photograph by USGS, 2005.

Figure 6. Examples of dense vegetation structure within breeding habitats of Southwestern Willow Flycatcher. 
Riparian patches used by breeding flycatchers vary in size and shape, ranging from a relatively contiguous stand of uniform vegetation to an irregularly shaped mosaic of dense vegetation with open areas. Southwestern Willow Flycatchers have nested in patches as small as 0.8 ha (for example, in the Grand Canyon) and as large as several hundred hectares (for example, at Roosevelt Lake, Ariz., or Elephant Butte Reservoir, New Mex.). They have only rarely been found nesting in isolated, narrow, linear riparian habitats that are less than 10 m wide, although they will use such linear habitats during migration.

Flycatcher territories and nests typically are adjacent to open water, cienegas, marshy seeps, or saturated soil, and within riparian areas rooted in standing water. However, in the Southwest, hydrological conditions at a site can vary remarkably within a season, between years, and among nearby sites (fig. 7). Surface water or saturated soil may only be

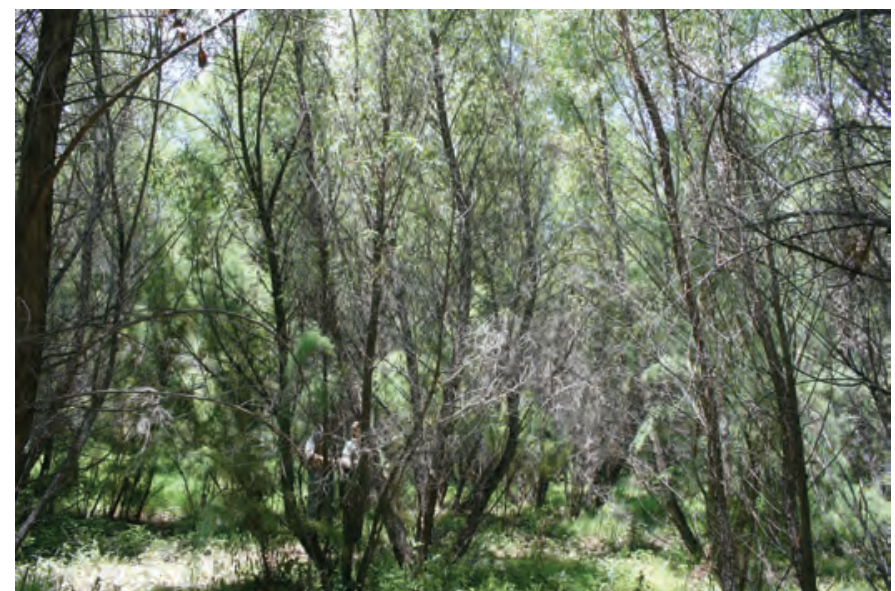

Rio Grande at San Marcial, New Mexico, with dry substrate. Photograph by USGS, 2007.

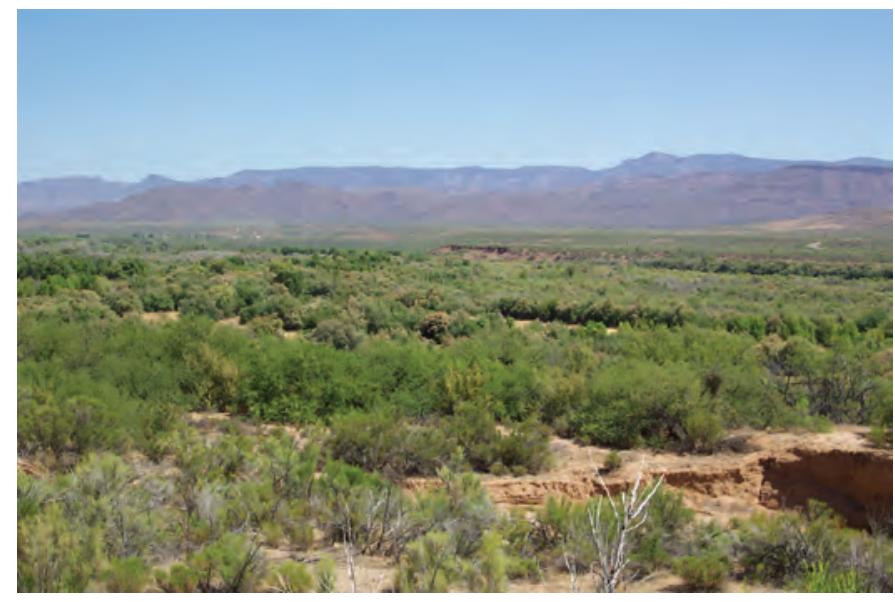

Tonto Creek inflow to Roosevelt Lake, Arizona, during a dry year. Photograph by USGS, 2004. present early in the breeding season (that is, May and part of June), especially in dry years. Similarly, vegetation at a patch may be immersed in standing water during a wet year, but be hundreds of meters from surface water in dry years (Ahlers and Moore, 2009). This is particularly true of reservoir sites, such as the Kern River at Lake Isabella, Calif., Tonto Creek and Salt River at Roosevelt Lake, and the Rio Grande near Elephant Butte Reservoir. Natural or human-caused river channel modifications and altered subsurface flows (for example, from agricultural runoff), can lead to a total absence of water or visibly saturated soil at a site for several years.

Other potentially important aspects of Southwestern Willow Flycatcher habitat include distribution and isolation of vegetation patches, hydrology, food base (arthropods), parasites, predators, environmental factors (for example temperature, humidity), and interspecific competition (U.S. Fish and Wildlife Service, 2002). Population dynamics

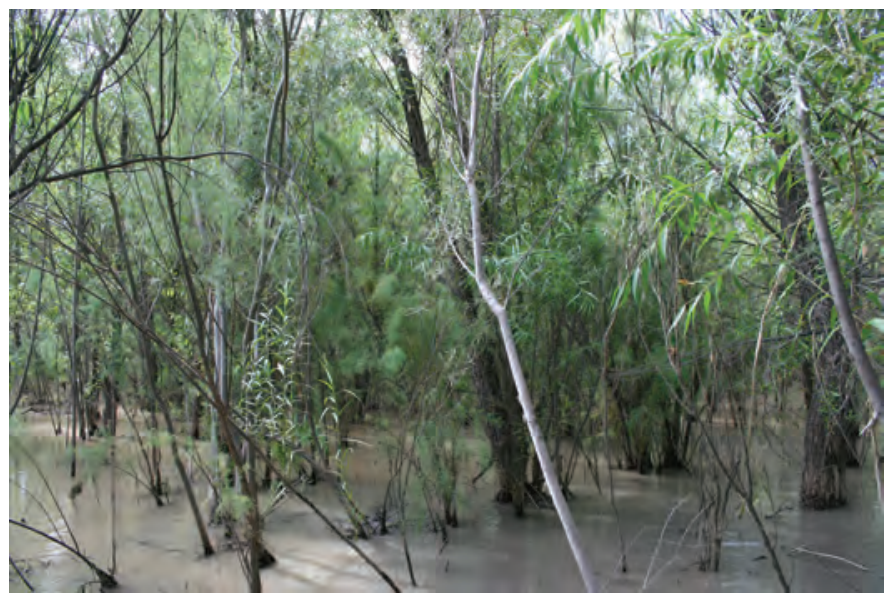

Rio Grande at San Marcial, New Mexico, with flowing water beneath the territories. Photograph by USGS, 2007.

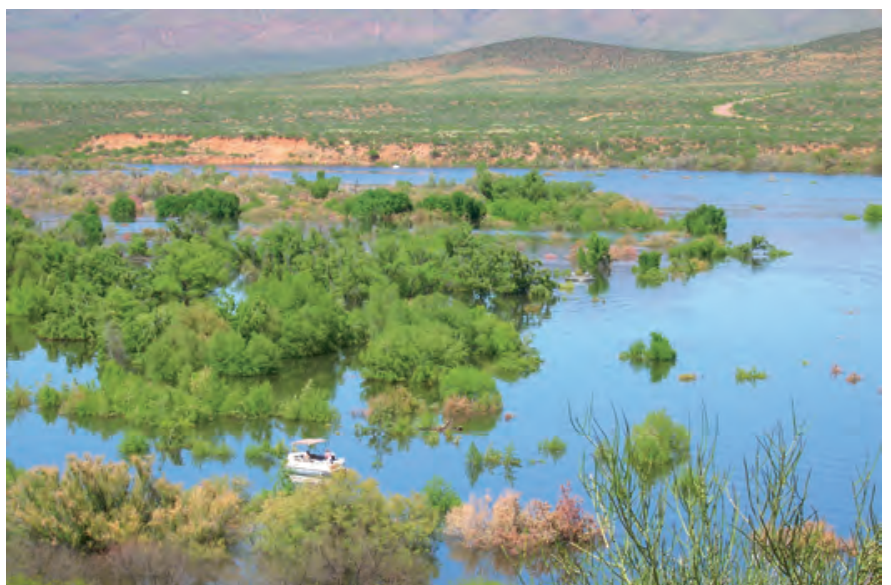

Tonto Creek inflow to Roosevelt Lake, Arizona, during high-water year. Photograph by USGS, 2005.

Figure 7. Examples of the variable hydrologic conditions at breeding habitats of Southwestern Willow Flycatcher. 
factors, such as demography (for example, survivorship rates, fecundity), distribution of breeding groups across the landscape, flycatcher dispersal patterns, migration routes, the tendency for adults and surviving young to return to their previous year breeding site, and conspecific sociality also influence where flycatchers are found and what habitats they use (U.S. Fish and Wildlife Service, 2002).

It is critically important to recognize that the ultimate measure of habitat suitability is not simply whether or not a site is occupied. Habitat suitability occurs along a gradient from high to poor to unsuitable; the best habitats are those in which flycatcher reproductive success and survivorship result in a stable or growing population. Some occupied habitats may be acting as population sources, while others may be functioning as population sinks (Pulliam, 1988). Therefore, it can take extensive research to determine the quality of any given habitat patch. Furthermore, productivity and survival rates can vary widely among years (Paxton and others, 2007; Ellis and others, 2008; Ahlers and Moore, 2009), so conclusions based on short-term datasets or data extrapolated from one area to another may be erroneous. It also is important to note that not all unoccupied habitat is unsuitable; some sites with suitable habitat may be geographically isolated or newly established, such that they are not yet colonized by breeding flycatchers. There also may simply not be enough flycatchers in a given area to fill all available habitat in particular locations (U.S. Fish and Wildlife Service, 2002). A better understanding of which habitats or sites are sinks or sources can be especially helpful in site conservation and restoration planning.

As described earlier, migrant Willow Flycatchers may occur in riparian habitats that are structurally unsuitable for breeding (for example, too sparse, smaller patch size, etc.), and in non-riparian habitats. Such migration stopover areas, even though not used for breeding, may be critically important resources affecting local and regional flycatcher productivity and survival (U.S. Fish and Wildlife Service, 2002, 2005).

\section{Breeding Chronology and Biology}

Unless otherwise noted, the information that follows and upon which the generalized breeding season chronology (fig. 8) is based comes from Unitt (1987), Whitfield (1990), Maynard (1995), Sogge and others (2003b), Paxton and others (2007), Schuetz and Whitfield (2007), and Ellis and others (2008). Extreme or record dates for any stage of the breeding cycle may vary by 1-2 weeks from the dates presented, depending on the geographic area, extreme weather events, yearly variation and other factors. Higher elevation areas, in particular, have delayed chronology (Ahlers and White, 2000).

\section{Generalized Breeding Season Chronology}

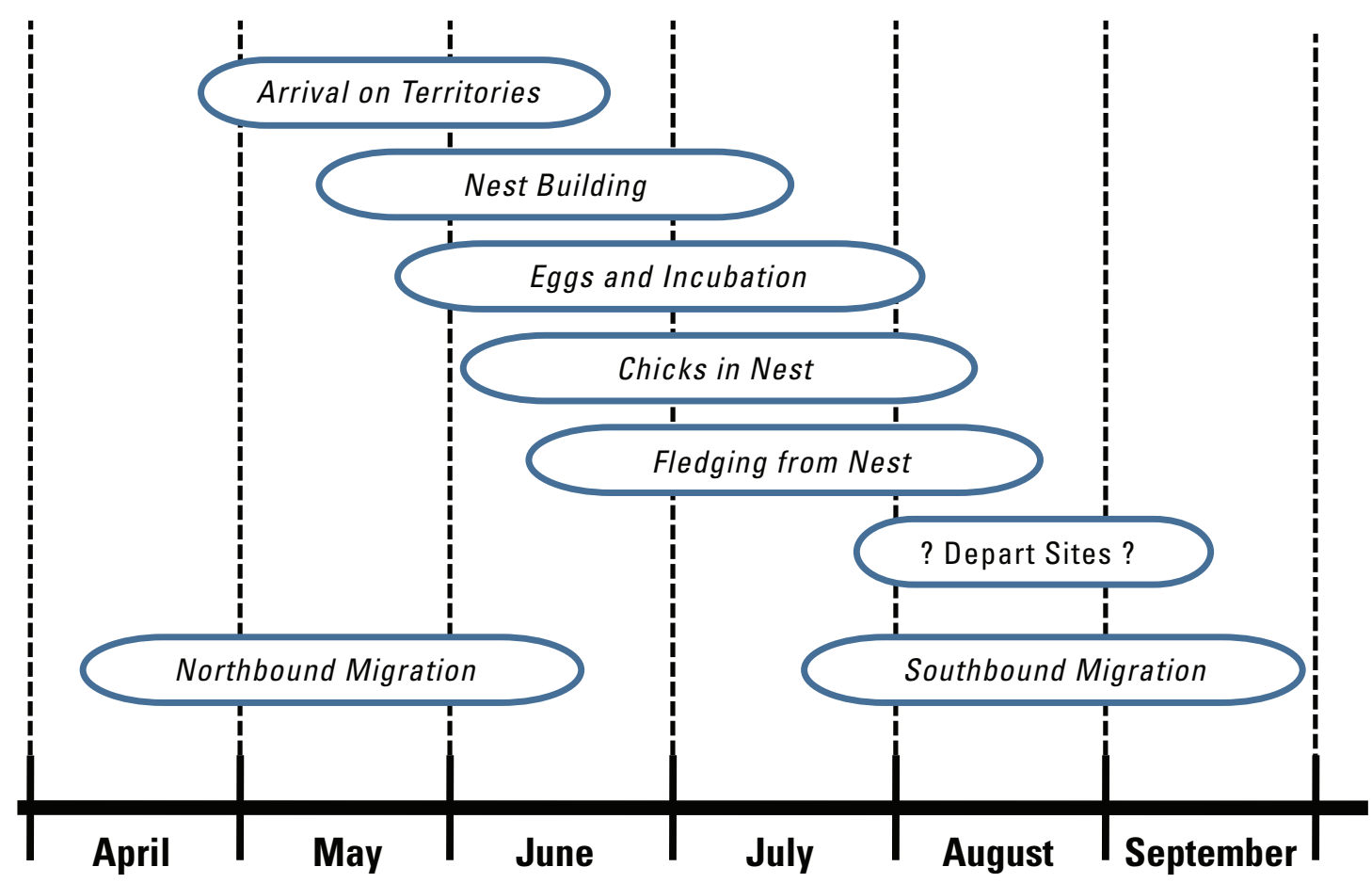

Figure 8. Generalized migration and breeding chronology for the Willow Flycatcher in the Southwest. Extreme or record dates may occur slightly earlier or later than indicated. 
Both sexes can breed beginning in their second year. Male Southwestern Willow Flycatchers generally arrive at breeding areas first; older males typically arrive before younger ones. Although females usually arrive a few weeks after males, some older females are present at sites before late-arriving males. Adult flycatchers will sometimes wander extensively through large riparian sites before and after breeding, possibly as a way to evaluate potential breeding habitat (Cardinal and others, 2006).

Males establish and defend their territories through singing and aggressive interactions. Females settle on established territories, and may choose a territory more for its habitat characteristics than for the traits of its territorial male. Territory size tends to be larger when a male first arrives, then gets smaller after a female pairs with the male (Cardinal and others, 2006). Similarly, male song rate is very high early in the season, then declines after pairing (Yard and Brown, 2003). Not all males are successful in attracting mates in a given year, and as a result unpaired territorial males occur at many breeding sites. Unpaired males are usually a small percentage of any local population, but can comprise as much as 15-25 percent of the territories in some populations (Munzer and others, 2005; Ahlers and Moore, 2009).

Although the Willow Flycatcher as a species is considered predominantly monogamous during the breeding season (Sedgwick, 2000), some Southwestern Willow Flycatcher populations have a relatively high degree of polygyny whereby one male can have more than one breeding female in its territory. Polygynous males generally have two females in their territory, but up to four have been recorded (Davidson and Allison, 2003; Pearson and others, 2006). Polygyny rates can vary between sites, and among years at a given site. At some sites, polygynous males have much higher productivity than monogamous males (Paxton and others, 2007).

Nest building within the territory usually begins within a week or two after pair formation. Egg laying begins as early as mid-May, but more often starts in late May to mid-June. Chicks can be present in nests from late May through early August. Young typically fledge from nests from mid-June through mid-August; later fledglings are often products of re-nesting attempts. Breeding adults generally depart from their territories in early to mid-August, but may stay later if they fledged young late in the season. Males that fail to attract or retain mates, and males or pairs that are subject to significant disturbance, such as repeated nest parasitism or predation may leave territories by early July. Fledglings probably leave the breeding areas a week or two after adults, but few details are known.

Southwestern Willow Flycatcher territory size varies widely, probably due to differences in population density, habitat quality (including vegetation density and food availability), and nesting stage. Studies have reported estimated territory sizes ranging from 0.06 to 2.3 ha (Sogge and others, 1995; Whitfield and Enos, 1996; Bureau of Reclamation, 2009). At Roosevelt Lake, Ariz., measurements of home ranges, which include the defended territory and sometimes adjacent use areas, averaged 0.4 ha for actively breeding males; home range can be much larger for preand post-breeding males (Paxton and others, 2007). During incubation and nestling phases territory size, or at least the activity centers of pairs, can be very small. Flycatchers may increase their activity area after young are fledged, and use non-riparian habitats adjacent to the breeding area (Cardinal and others, 2006). This variability among sites, individual territories, and over time illustrates the challenge of defining a minimum habitat patch size for breeding flycatchers, or estimating the number of territories based simply on the size of a given breeding site.

At some breeding sites, non-territorial adult "floaters" will be present among the territorial population. Floaters are quieter and less aggressive than territorial adults, and therefore are harder to detect and frequently overlooked. Most floaters are young males, and float for only a single year. At Roosevelt Lake, floaters typically accounted for 3-8 percent of the known adult population, although the rate was much higher in drought years when habitat quality was lower (Paxton and others, 2007). The presence of floaters in a population may indicate that there is not enough high quality habitat to support all potentially territorial individuals present in a given breeding season.

\section{Nests and Eggs}

Historically, 75-80 percent of reported Southwestern Willow Flycatcher nests were placed in willows (Phillips, 1948; Phillips and others, 1964; Hubbard, 1987; Unitt, 1987). Southwestern Willow Flycatchers still commonly place their nests in native plants, but will often build nests in exotics, such as saltcedar and Russian olive (Sogge and Marshall, 2000; Stoleson and Finch, 2003; Durst and others, 2008a). In Arizona, most nests are in saltcedar or willows (Paradzick and Woodward, 2003; McLeod and others, 2007). In a unique situation in San Diego County, Calif., the flycatcher nests in coast live oak (Quercus agrifolia) along the San Luis Rey River (Haas, 2003), where oak became the dominant plant species adjacent to the river following willow removal in the 1950s. In another unusual situation, flycatchers in the Cliff-Gila Valley in New Mex. nest in tall boxelder (Stoleson and Finch, 2003). Southwestern Willow Flycatcher nests also have been found in buttonbush, black twinberry (Lonicera involucrata), Fremont cottonwood (Populus fremontii), alder (Alnus spp.), blackberry (Rubus ursinus), baccharis (Baccharis spp.), and stinging nettle (Urtica spp.). Overall, flycatcher nest site selection appears to be driven more by plant structure than by species composition. 
Southwestern Willow Flycatchers build open cup nests approximately $8 \mathrm{~cm}$ high and $8 \mathrm{~cm}$ wide (outside dimensions), exclusive of any dangling material at the bottom. Females build the nest with little or no assistance from the males. Nests typically are placed in the fork of a branch with the nest cup supported by several small-diameter vertical stems. Nest height is highly variable and depends on the available plant structure within the territory; nests have been found from $0.6 \mathrm{~m}$ to approximately $20 \mathrm{~m}$ above ground. In any given habitat type or nest substrate, nests can be placed wherever suitable twig structure and vegetative cover are present.

Egg laying generally begins from mid-May through mid-June, depending on the geographic area and elevation. Willow Flycatcher eggs are buffy or light tan, approximately $18 \mathrm{~mm}$ long and $14 \mathrm{~mm}$ wide, with brown markings in a wreath at the blunt end. Clutch size is usually three or four eggs for first nests. Only the female develops a brood patch and incubates the eggs. Incubation lasts 12-13 days from the date the last egg is laid, and all eggs typically hatch within 24-48 hours of each other.

Flycatcher chicks are altricial and weigh only about 1-2 $\mathrm{g}$ at hatching, but grow rapidly and are ready to leave the nest at 12-15 days of age (Sedgwick, 2000; Paxton and Owen, 2002). The female provides most or all initial care of the young, although the role of the male increases with the age and size of nestlings. After Willow Flycatchers fledge at 12-15 days of age, they stay close to the nest and each other for 3-5 days, and adults continue feeding the fledged young for approximately 2 weeks. Recently fledged birds may repeatedly return to and leave the nest during this period (Spencer and others, 1996). Both male and female adults feed the fledged young, which give frequent, loud "peep" calls.

Southwestern Willow Flycatchers readily re-nest following an unsuccessful nesting attempt, although rarely more than once (Ellis and others, 2008). They also will sometimes nest again (double brood) following a successful nesting attempt, although this is more uncommon than re-nesting and varies between sites and years. From 2002 to 2008 at Elephant Butte Reservoir, approximately 13 percent of the pairs produced two successful nests per year (Ahlers and Moore, 2009). The productivity gains from pairs having successful second nests are important drivers of positive population growth (Paxton and others, 2007; Moore and Ahlers, 2009).

Replacement nests are built in the same territory, either in the same plant or at a distance of as much as $20 \mathrm{~m}$ from the previous nest. Reuse of old nests is uncommon, but does occur (Yard and Brown, 1999; Darrell Ahlers, Bureau of Reclamation, unpub. data, 2009). Replacement nest building and egg laying can occur (uncommonly) as late as the end of July or early August. Pairs may attempt a third nest if the second fails. However, clutch size, and therefore potential productivity, decreases with each nest attempt (Whitfield and Strong, 1995; Ellis and others, 2008).

\section{Food and Foraging}

The breeding season diet of Southwestern Willow Flycatchers is relatively well documented (DeLay and others, 2002; Drost and others, 2003; Durst, 2004; Wiesenborn and Heydon, 2007; Durst and others, 2008b). Breeding flycatchers are exclusively insectivorous, and consume a wide range of prey taxa ranging in size from small leafhoppers (Homoptera) to large dragonflies (Odonata). Major prey taxa include bugs (Hemiptera), bees and wasps (Hymenoptera), flies (Diptera), and leafhoppers; however, diet can vary widely between years and among different habitat types. There is no known differences in diet by sex, but there are differences between adult and nestling diet in the proportions of some arthropod groups. Differences in the composition of arthropods in flycatcher diet have been documented between native and exotic habitats, and between years within particular breeding sites; however, flycatchers appear able to tolerate substantial variation in relative prey abundance, except in extreme situations such as severe droughts (Durst and others, 2008b).

Willow Flycatchers of all subspecies forage primarily by sallying from a perch to perform aerial hawking and gleaning (Sedgwick, 2000; Durst, 2004). Males and females forage with similar maneuvers, although males may forage higher in the tree canopy than females. Foraging frequently takes place at external edges or internal openings within a habitat patch, or at the top of the upper canopy.

\section{Site Fidelity and Survivorship}

Based on studies of banded birds, most adult Southwestern Willow Flycatchers that survive from one year to the next will return to the same river drainage, often in proximity to the same breeding site (U.S. Fish and Wildlife Service, 2002; McLeod and others, 2007; Paxton and others, 2007). However, it is common for individual flycatchers to return to different sites within a breeding area, and even to move between breeding areas, from one year to the next. Some of this movement may be related to breeding success and habitat quality. At Roosevelt Lake, those birds that moved to different sites within a breeding area had on average higher productivity in the year following the move than in the year before the move (Paxton and others, 2007). At Roosevelt Lake and on the San Pedro and Gila Rivers, movement out of breeding patches also increased with the relative age of a patch, which may indicate a preference for younger riparian vegetation structure.

In addition to movements within a breeding site, long-distance movements within and between drainages have been observed (Paxton and others, 2007), at distances up to approximately $450 \mathrm{~km}$. Dispersal of first-year flycatchers is more extensive than adult birds, as typical for most bird species. 
Survivorship within the breeding season can be very high, averaging 97 percent at Roosevelt Lake (Paxton and others, 2007). Between-year survivorship of adults can be highly variable, but appears to be similar to that of most small passerine birds studied, with estimates generally ranging from approximately 55 to 65 percent (Stoleson and others, 2000; McLeod and others, 2007; Paxton and others, 2007; Schuetz and Whitfield, 2007). Males and females have similar survivorship rates.

Estimated survivorship of young birds (from hatching to the next breeding season) is highly variable, depending in part on how the estimates are generated (Stoleson and others, 2000). Generally reported as between 15 and 40 percent, juvenile survivorship typically is lower than adult survivorship (Whitfield and Strong, 1995; Stoleson and others, 2000; McLeod and others, 2007). Early fledging young have higher survivorship than those that leave the nest later in the season (Whitfield and Strong, 1995; Paxton and others, 2007). Most flycatchers survive for only 1-2 adult years, and mean life expectancy in Arizona was estimated to be 1.9 years following fledging. However, some individuals live much longer. The maximum reported ages of banded Southwestern Willow Flycatchers are 9-11 years (Sedgwick, 2000; Paxton and others, 2007).

Overall, the Southwestern Willow Flycatcher population appears to persist as one or more widely dispersed metapopulations (Busch and others, 2000; U.S. Fish and Wildlife Service, 2002), with movement of individuals, and thus genetic exchange, occurring across the landscape. However, the amount of movement and interchange is lower among sites that are farther apart or more isolated. Some sites serve as population sources while others may be sinks; some sites will be ephemeral over periods of years or decades. Flycatcher movement and dispersal among sites is important for initial site colonization and subsequent recolonization.

There are few general predictors for the persistence of breeding sites. Relatively large populations, such as the Kern River Preserve, San Pedro River, Elephant Butte Reservoir, and the Gila River have persisted for 10 or more years. However, such large sites can be subject to major changes in population numbers, and even potential extirpation, due to changes in local hydrology, site inundation, drought, etc. (Moore, 2005; Paxton and others, 2007). Although some small populations may be ephemeral and last only a few years (Durst and others, 2008a), others have remained occupied for much longer periods (Kus and others, 2003). Breeding populations also may reappear at unoccupied sites following 1-5 year absences. Suitable flycatcher habitat also can develop-and poor quality habitat can improve-relatively quickly in some sites, under favorable hydrological conditions. For example, at Roosevelt Lake and the San Pedro River (AZ), the age of riparian vegetation when first colonized was as young as 3 years (Paxton and others, 2007). In the same study, flycatchers moved back into older habitat patches when nearby younger, occupied habitat was inundated or scoured away.

Overall, the vegetation and flycatcher occupancy of a habitat patch or river drainage are often dynamic; few if any sites remain static over time. The amount of suitable flycatcher habitat can substantially increase or decrease in just a few years, at local and regional scales. Flycatchers can respond quickly to habitat changes, colonizing new sites if available and abandoning others. Therefore, one cannot assume that local, regional, or rangewide flycatcher population numbers will remain stable over time.

\section{Threats to the Flycatcher and Habitat}

The greatest historical factor in the decline of the Southwestern Willow Flycatcher is the extensive loss, fragmentation, and modification of riparian breeding habitat (U.S. Fish and Wildlife Service, 2002). Large-scale losses of southwestern wetlands have occurred, particularly the cottonwood-willow riparian habitats historically used by the Southwestern Willow Flycatcher (Unitt, 1987; General Accounting Office, 1988; Dahl, 1990; State of Arizona, 1990). Changes in the riparian plant community have frequently reduced, degraded, and eliminated nesting habitat for the flycatcher, curtailing its distribution and abundance.

Habitat losses and changes have occurred and continue to occur because of urban, recreational, and agricultural development, water diversion and impoundment, channelization, livestock grazing, and replacement of native habitats by introduced plant species (Marshall and Stoleson, 2000; U.S. Fish and Wildlife Service, 2002). Hydrological changes, natural or man-made, can greatly reduce the quality and extent of flycatcher habitat. Although riparian areas are often not considered as fire-prone, several Southwestern Willow Flycatcher breeding sites were destroyed by fire over the past decade (U.S. Fish and Wildlife Service, 2002), and others are at risk to similar catastrophic loss. Fire danger in these riparian systems may be exacerbated by increases in exotic vegetation, such as saltcedar, diversions or reductions of surface water, increased recreational activity, and drawdown of local water tables.

Although the degradation of many river systems and associated riparian habitat is a key cause of their absence, Southwestern Willow Flycatchers do not require free-running rivers or "pristine" riparian habitats. Most of the largest 
Southwestern Willow Flycatcher populations in the last decade were found in reservoir drawdown zones, such as at Roosevelt Lake and Elephant Butte Reservoir. Many breeding populations are found on regulated rivers (Graf and others, 2002). In addition, the vegetation at many smaller flycatcher breeding sites is supported by artificial water sources such as irrigation canals, sewage outflow, or agricultural drainages (U.S. Fish and Wildlife Service, 2002). Although rising water levels could be detrimental to breeding flycatchers within a reservoir drawdown zone, reservoir fluctuations can simulate river dynamics with cycles of destruction and establishment of riparian vegetation, depositing rich sediments and flushing salt accumulations in the soil (Paxton and others, 2007). Therefore, managed and manipulated rivers and reservoirs have the potential to play a positive role by providing flycatcher breeding habitat. However, because rivers and reservoirs are not managed solely to create and maintain flycatcher habitat, the persistence of riparian vegetation in these systems — and any flycatchers breeding therein - is not assured.

Although the historic degradation and loss of native riparian negatively affected the Southwestern Willow Flycatcher, this species does not show an inherent preference for native vegetation. Instead, breeding habitat selection is based primarily on vegetation structure, density, size, and other stand characteristics, and presence of water or saturated soils (U.S. Fish and Wildlife Service, 2002). In fact, approximately 25 percent of known territories are found in habitat composed of 50 percent or greater exotic vegetative component—primarily saltcedar (Durst and others, 2008a). Saltcedar also can be an important habitat component in sites dominated by native vegetation (U.S. Fish and Wildlife Service, 2002, 2005). Despite suggestions that flycatchers breeding in saltcedar are suffering negative consequences and that removal of saltcedar is therefore a benefit (DeLoach and others, 2000; Dudley and DeLoach, 2004), there is increasing and substantial evidence that this is not the case. For example, Paxton and others (2007) found that flycatchers did not suffer any detectable negative consequences from breeding in saltcedar. This is consistent with the findings of Owen and others (2005) and Sogge and others (2006). Therefore, the rapid or large-scale loss of saltcedar in occupied flycatcher habitats, without rapid replacement of suitable native vegetation, could result in reduction or degradation of flycatcher habitat (U.S. Fish and Wildlife Service, 2002; Sogge and others, 2008).
In evaluating Southwestern Willow Flycatcher use of either native or exotic habitat, it is important to recognize that throughout the Southwest, there are many saltcedar-dominated and native-dominated habitats in which flycatchers do not breed (U.S. Fish and Wildlife Service, 2002; Sogge and others, 2006). Therefore, the use of any riparian patch—native or exotic - as breeding habitat will be site specific and will depend on the spatial, structural, and ecological characteristics of that particular patch and the potential for flycatchers to colonize and maintain populations within it.

Drought can have substantial negative effects on breeding flycatchers and their breeding habitat by reducing riparian vegetation vigor and density, and reducing prey availability (Durst, 2004; Paxton and others, 2007; Bureau of Reclamation, 2009). For example, the extreme drought of 2002 caused near complete reproductive failure of the large flycatcher population at Roosevelt Lake; among approximately 150 breeding territories, only two nests successfully fledged young in that year (Ellis and others, 2008). If future climate change produces more frequent or more sustained droughts, as predicted by many climate change models (for example, Seager and others, 2007), southwestern riparian habitats could be reduced in extent or quality. This scenario would present a challenge to the long-term sustainability of Southwestern Willow Flycatcher populations.

Brood parasitism by the Brown-headed Cowbird (Molothrus ater) was initially considered another significant threat to the Southwestern Willow Flycatcher (Whitfield, 1990; Harris, 1991; U.S. Fish and Wildlife Service, 1993, 1995; Whitfield and Strong, 1995; Sferra and others, 1997). Cowbirds lay their eggs in the nest of other species (the "hosts"), which raise the young cowbirds —often at the expense of reduced survivorship of their own young. Southwestern Willow Flycatchers seldom fledge any flycatcher young from nests that are parasitized by cowbirds (Whitfield and Sogge, 1999). Although parasitism negatively impacts some Southwestern Willow Flycatcher populations, especially at small and isolated breeding sites, it is highly variable and no longer considered among the primary rangewide threats to flycatcher conservation (U.S. Fish and Wildlife Service, 2002). Cowbird abundance, and therefore parasitism, tends to be a function of habitat type and quality, and the availability of suitable hosts, not specific to the flycatcher. Therefore, largescale cowbirds control may not always be warranted unless certain impact thresholds are met (U.S. Fish and Wildlife Service, 2002; Rothstein and others, 2003; Siegle and Ahlers, 2004). 


\section{Section 2. Survey Protocol}

The fundamental principles of the methodology described in this version have remained the same since the original Tibbitts and others (1994) and subsequent Sogge and others (1997a) protocols: the use of vocalization play-back, repeated site visits, and confirmation of flycatcher identity via the species-characteristic song. This newest protocol incorporates guidelines of the 2000 USFWS addendum, and includes changes based on our improved understanding of Willow Flycatcher biology and the significance of potential threats, and the availability of new survey technologies.

Several factors work together to make Southwestern Willow Flycatcher surveys challenging. Difficulties include the flycatcher's physical similarities with other species and subspecies; accessing the dense habitat they occupy; time constraints based on their breeding period; and vocalization patterns. Given these challenges, no methodology can assure 100 -percent detection rates. However, the survey protocol described herein has proven to be an effective tool for locating flycatchers, and flycatchers generally are detectable when the protocol is carefully followed. Since 1995, hundreds of sites have been surveyed and thousands of flycatchers detected using the two previous versions of the survey protocol.

The Willow Flycatcher is 1 of 10 regularly occurring Empidonax flycatchers found in North America, all of which look very much alike. Like all Empidonax, Willow Flycatchers are nondescript in appearance, making them difficult to see in dense breeding habitat. Although the Willow Flycatcher has a characteristic fitz-bew song that distinguishes it from other birds (including other Empidonax), Willow Flycatchers are not equally vocal at all times of the day or during all parts of the breeding season. Because Southwestern Willow Flycatchers are rare and require relatively dense riparian habitat, they may occur only in a small area within a larger riparian system, thus decreasing detectability during general bird surveys. Migrating Willow Flycatchers (of all subspecies) often sing during their migration through the Southwest, and could therefore be confused with local breeders. In addition, Southwestern Willow Flycatchers are in breeding areas for only 3-4 months of the year. Surveys conducted too early or late in the year would fail to find flycatchers even at sites where they breed.

These life history characteristics and demographic factors influence how Southwestern Willow Flycatcher surveys should be conducted and form the basis upon which this protocol was developed. This protocol is based on the use of repeated call-playback surveys during pre-determined periods of the breeding season, to confirm presence or to derive a high degree of confidence regarding their absence at a site. Such species-specific survey techniques are necessary to collect reliable presence/absence information for rare species (Bibby and others, 1992).
The primary objective of this protocol is to provide a standardized survey technique to detect Southwestern Willow Flycatchers, determine breeding status, and facilitate consistent and standardized data reporting. The survey technique will, at a minimum, help determine presence or absence of the species in the surveyed habitat for that breeding season. Ultimately, the quality of the survey that is conducted will depend on the preparation, training, and in-the-field diligence of the individual surveyor.

This protocol is designed for use by persons who are non-specialists with Empidonax flycatchers or who are not expert birders. However, surveyors must have sufficient knowledge, training, and experience with bird identification and surveys to distinguish the Willow Flycatcher from other non-Empidonax species, and be able to recognize the Willow Flycatcher's primary song. A surveyor's dedication and attitude, willingness to work early hours in dense, rugged and wet habitats, and their ability to remain alert and aware of important cues also are important. Surveys conducted improperly or by unqualified, inexperienced, or complacent personnel may lead to inaccurate results and unwarranted conclusions.

Surveys conducted by qualified personnel in a consistent and standardized manner will enable continued monitoring of general population trends at and between sites, and between years. Annual or periodic surveys in cooperation with State and Federal agencies should aid resource managers in gathering basic information on flycatcher status and distribution at various spatial scales. Identifying occupied and unoccupied sites will assist resource managers in assessing potential impacts of proposed projects, avoiding impacts to occupied habitat, identifying suitable habitat characteristics, developing effective restoration management plans, and assessing species recovery.

The earlier versions of this protocol (Tibbitts and others, 1994; Sogge and others, 1997a) were used extensively and successfully for many years. Hundreds of flycatcher surveys conducted throughout the Southwest since 1994 revealed much about the usefulness and application of this survey technique. Three important lessons were: (1) the call-playback technique works and detects flycatchers that would have otherwise been overlooked; (2) multiple surveys at each site are important; and (3) with appropriate effort, general biologists without extensive experience with Empidonax can find and verify Willow Flycatcher breeding sites.

This revised protocol is still based on call-playback techniques and detection of singing individuals. However, it includes changes in the timing and number of surveys to increase the probability of detecting flycatchers and to help determine if they are breeders or migrants. It also incorporates the basic premise of the USFWS 2000 addendum to the 1997 protocol by requiring a minimum of five surveys in all "project-related" sites. A detailed description of surveys and 
timing is discussed in section, "Timing and Number of Visits." Changes in the survey data sheets make them easier to use and submit, and allow reporting all site visits within a single year on one form. The new survey forms also are formatted such that the data on the respective forms can be easily incorporated into the flycatcher range-wide database.

This protocol is intended to determine if a habitat patch contains territorial Southwestern Willow Flycatchers, and is not designed establish the exact distribution and abundance of flycatchers at a site. Determining precise flycatcher numbers and locations requires many more visits and additional time observing the behavior of individual birds. This survey protocol also does not address issues and techniques associated with nest monitoring or other flycatcher research activities. Those efforts are beyond the scope usually needed for most survey purposes, and require advanced levels of experience and skills to gather useful data and avoid potential negative effects to the flycatcher. If nest monitoring is a required component of your study, refer to Rourke and others (1999) for appropriate nest monitoring techniques (available for download at http://sbsc.wr.usgs.gov/cprs/research/projects/ swwf/reports.asp).

Biologists who are not expert birders or specialists with regard to Empidonax flycatchers can effectively use this protocol. However, users should attend a U.S. Fish and Wildlife Service-approved Southwestern Willow Flycatcher survey training workshop, and have knowledge and experience with bird identification, surveys, and ecology sufficient to effectively apply this protocol.

\section{Permits}

Federal endangered species recovery permits are required for surveys in all USFWS regions where the Southwestern Willow Flycatcher breeds (application forms can be downloaded at http://www.fws.gov/forms/3-200-55. pdf). State permits also may be required before you can survey within any of the States throughout the Southwestern Willow Flycatcher's range: be certain to check with the appropriate State wildlife agency in your area. It usually takes several months to receive permits, so apply early to avoid delays in starting your surveys. You also must obtain permission from government agencies and private landowners prior to conducting any surveys on their lands.

\section{Pre-Survey Preparation}

The degree of effort invested in pre-survey preparation will have a direct effect on the quality and efficiency of the surveys conducted. Pre-survey preparation is often overlooked, but can prove to be one of the more important aspects in achieving high-quality survey results.
Surveyors should study calls, songs, drawings, photographs, and videos of Willow Flycatchers. Several web sites describe life history requirements, and provide photographs and vocalizations. It is especially critical for surveyors to be familiar with Willow Flycatcher vocalizations before going in the field. Although the fitz-bew song is the basis of verifying detections using this protocol, Willow Flycatchers use many other vocalizations that are valuable in locating birds and breeding sites. We strongly encourage that all surveyors learn as many vocalizations as possible and refer to the on-line "Willow Flycatcher Vocalizations; a Guide for Surveyors” (available at http://sbsc.wr.usgs.gov/cprs/research/ projects/swwf/wiflvocl.asp). Several commercial bird song recordings include Willow Flycatcher vocalizations, but these recordings typically have only a few vocalizations and the dialects may differ from those heard in the Southwest.

If possible, visit known Willow Flycatcher breeding sites to become familiar with flycatcher appearance, behavior, vocalizations, and habitat. Such visits are usually part of the standardized flycatcher survey workshops. All visits should be coordinated with USFWS, State wildlife agencies, and the property manager/owner, and must avoid disturbance to territorial flycatchers. While visiting these sites, carefully observe the habitat characteristics to develop a mental image of the key features of suitable habitat.

Surveyors must be able to identify, by sight and vocalizations, other species likely to be found in survey areas that may be confused with Southwestern Willow Flycatchers. These include Bell's Vireo (Vireo bellii), Western Woodpewee (Contopus sordidulus), young or female Vermillion Flycatchers (Pyrocephalus rubinus), and other Empidonax flycatchers. At a distance, partial song or call notes of Bell's Vireo, Ash-throated Flycatchers (Myiarchus cinerascens) and some swallows can sound considerably like a fitz-bew. Surveyors also should be able to identify Brown-headed Cowbirds by sight and vocalizations. It is worthwhile to make one or more pre-survey trips to the survey sites or other similar areas to become familiar with the local bird fauna. You might consider obtaining a species list relative to your area and become familiar with those species by site and sound.

Prior to conducting any presence/absence surveys in your respective State or USFWS Region, contact the respective flycatcher coordinators to discuss the proposed survey sites and determine if the sites have been surveyed in prior years. If possible, obtain copies of previous survey forms and maintain consistency with naming conventions and site boundaries. Study the forms to determine if flycatchers have been previously detected in the site, record locations of any previous detections, and read the comments provided by prior surveyors. While surveying, be sure to pay special attention to any patches where flycatchers have previously been detected. 
Familiarity with the survey site prior to the first surveys is the best way to be prepared for the conditions you will experience. Determine the best access routes to your sites and always have a back-up plan available in the event of unforeseen conditions (for example, locked gates, weather, etc.). Know the local property boundaries and where the potential hazards may be, including deep water, barbed wire fencing, and difficult terrain. Be prepared to work hard and remain focused and diligent in a wide range of physically demanding conditions. At many sites, these include heat, cold, wading through flowing or stagnant water, muddy or swampy conditions, crawling through dense thickets (often on hands and knees), and exposure to snakes, skunks, and biting insects.

It is imperative that all surveyors exercise the adage "safety first." Be aware of safety hazards and how to avoid them, and do not allow the need to conduct surveys to supersede common sense and safety. Inform your coworkers where you will be surveying and when you anticipate returning. Always take plenty of water and know how to effectively use your equipment, especially compass, Global Positioning System (GPS), and maps.

\section{Equipment}

The following equipment is necessary to conduct the surveys:

1. USGS topographic maps of the area: A marked copy is required to be attached to survey data sheets submitted at the end of the season. Be sure to always delineate the survey area and clearly mark any flycatcher detections. If the survey area differed between visits; delineate each survey individually.

2. Standardized survey form: Always bring more copies than you think you need.

3. Lightweight audio player: Be sure the player has adequate volume to carry well; use portable speakers if necessary. Several digital devices, such as CD players and MP3 players, are currently available and can be connected to external amplified speakers for broadcasting the flycatcher vocalizations. However, not all are equally functional or effective in field conditions; durability, reliability, and ease of use are particularly important. Talk to experienced surveyors for recommendations on particular models and useful features.

4. Extra player and batteries: In the field, dirt, water, dust, and heat often cause equipment failure, and having backup equipment helps avoid aborting a survey due to equipment loss or failure.

5. Clipboard and permanent (waterproof) ink pen: We recommend recording survey results directly on the survey data form, to assure that you collect and record all required data and any field notes of interest.

6. Aerial photographs: Aerial photographs can significantly improve your surveys by allowing you to accurately target your efforts, thus saving time and energy in the field. Previously, aerial images were often expensive and difficult to obtain. However, it is now easy to get free or low-cost images from sources, such as Google ${ }^{\odot}$ Earth. Even moderate resolution images generally are better than none. For higher resolution aerial photographs, check with local planning offices and/or State/Federal land-management agencies for availability. Take color photocopies, not the original aerial photographs, with you in the field. Aerial photographs also are very useful when submitting your survey results but cannot be substituted in lieu of the required topographic map.

7. Binoculars and bird field guide: Although this protocol relies primarily on song detections to verify flycatcher presence, good quality binoculars are still a crucial field tool to help distinguish between possible Southwestern Willow Flycatchers and other species. Use a pair with 7-10 power magnification that can provide crisp images in poor lighting conditions. A good field guide also is essential for the same reason.

8. GPS unit: A GPS unit is needed for determining survey coordinates and verifying the location of survey plots on topographic maps. All flycatcher detections should be stored as waypoints and coordinates recorded on the survey form. A wide variety of fairly inexpensive GPS units are currently available. Most commercially available units will provide accuracy within $10 \mathrm{~m}$, which is sufficient for navigating and marking locations.

9. Compass: Surveyors should carry a compass to help them while navigating larger habitat patches. This is an important safety back-up device, because GPS units can fail or lose power. Most GPS units have a feature to provide an accurate bearing to stored waypoints (for example, previous flycatcher detections, your parked vehicle, etc.); however, many units do not accurately display the direction in which the surveyor is traveling slowly through dense vegetation. A compass set to the proper bearing provides a more reliable method to navigate the survey site and relocate previously marked locations.

The following equipment also is recommended:

10. Camera: These are very helpful for habitat photographs, especially at sites where flycatchers are found. Small digital cameras are easily portable and relatively inexpensive.

11. Survey flagging: Used for marking survey sites or areas where flycatcher are detected. Check with the local land owner or management agency before flagging sites. Use flagging conservatively so as to not attract people or predators.

12. Field vest: A multi-pocket field vest can be very useful for carrying field equipment and personal items. We recommend muted earth-tone colors. 
13. Cell phone and/or portable radio: In addition to providing an increased level of safety, cell phones or portable radios may be used by surveyors to assist each other in identifying territories and pairs in dense habitats, or where birds are difficult to hear.

In addition to the necessary equipment mentioned above, personal items, such as food, extra water or electrolyte drink, sunscreen, insect repellent, mosquito net, first-aid kit, whistle, and a light jacket, also should be considered. Being prepared for unforeseen difficulties, and remaining as comfortable as conditions allow while surveying are important factors to conducting thorough and effective surveys.

All survey results (both negative and positive) should be recorded directly on data forms when possible. These data forms have been designed to prompt surveyors to record key information that is crucial to interpretation of survey results and characterization of study sites. Even if no flycatchers are detected or habitat appears unsuitable, this is valuable information and should be recorded. Knowing where flycatchers are not breeding can be as important as knowing where they are; therefore, negative data are important. Standardized data forms are provided in appendix 1 , or can be downloaded online. Always check for updated forms prior to each year's surveys.

Willow Flycatcher surveys are targeted at this species and require a great deal of focused effort. Surveyors must be constantly alert and concentrate on detecting a variety of flycatcher cues and responses. Therefore, field work, such as generalized bird surveys (for example, point counts or walking transects) or other distracting tasks, should not be conducted in conjunction with Willow Flycatcher surveys. Avoid bringing pets or additional people who are not needed for the survey. Dress in muted earth-tone colors, and avoid wearing bright clothing.

\section{Willow Flycatcher Identification}

The Southwestern Willow Flycatcher is a small bird, approximately $15 \mathrm{~cm}$ long and weighing about 11-12 g. Sexes look alike and cannot be distinguished by plumage. The upper parts are brownish-olive; a white throat contrasts with the pale olive breast, and the belly is pale yellow. Two white wing bars are visible (juveniles have buffy wing bars) and the eye ring is faint or absent. The upper mandible is dark and the lower mandible light. The tail is not strongly forked. When perched, the Willow Flycatcher often flicks its tail upward. As a group, the Empidonax flycatchers are very difficult to distinguish from one another by appearance. The Willow Flycatcher also looks very similar to several other passerine species you may encounter in the field.

Given that Willow Flycatchers look similar to other Empidonax flycatchers that may be present at survey sites, the most certain way to verify Willow Flycatchers in the field is by their vocalization. For the purpose of this protocol, identification of Willow Flycatchers cannot be made by sight alone; vocalizations are a critical identification criterion, and specifically the primary song fitz-bew. Willow Flycatchers have a variety of vocalizations (see Stein, 1963; Sedgwick, 2000), but two are most commonly heard during surveys or in response to call-playback:

1. Fitz-bew. This is the Willow Flycatcher's characteristic primary song. Note that fitz-bews are not unique to the southwestern subspecies; all Willow Flycatchers sing this characteristics song. Male Willow Flycatchers may sing almost continuously for hours, with song rates as high as one song every few seconds. Song volume, pitch, and frequency may change as the season progresses. During prolonged singing bouts, fitz-bews are often separated by short britt notes. Fitz-bews are most often given by a male, but studies have shown female Willow Flycatchers also sing, sometimes quite loudly and persistently (although generally less than males). Flycatchers often sing from the top of vegetation, but also will vocalize while perched or moving about in dense vegetation.

2. Whitt. This is a call often used by nesting pairs on their territory, and commonly is heard even during periods when the flycatchers are not singing (fitz-bewing). The whitt call appears to be a contact call between sexes, as well as an alarm call, particularly when responding to disturbance near the nest. Whitt calls can be extremely useful for locating Willow Flycatchers later in the season when fitz-bewing may be infrequent, but are easily overlooked by inexperienced surveyors. When flycatcher pairs have active nests and particularly once young have hatched, whitts may be the most noticeable vocalization. However, many species of birds whitt, and a whitt is not a diagnostic characteristic for Willow Flycatchers. For example, the "whitt" of the Black-headed Grosbeak (Pheucticus melanocephalus) and Yellow-breasted Chat (Icteria virens) are often confused with that of the flycatcher.

The fitz-bew and whitt calls are the primary vocalizations used to locate Willow Flycatchers. However, other less common Willow Flycatcher vocalizations can be very useful in alerting surveyors to the presence of flycatchers. These include twittering vocalizations typically given during interactions between flycatchers and sometimes between flycatchers and other birds, bill snapping, britt's, and wheeo's. Because these sounds can be valuable in locating territories (Shook and others, 2003), they should be studied prior to going in the field. Willow Flycatcher vocalization recordings are available from Federal and State agency contacts and online at http://sbsc.wr.usgs.gov/cprs/research/projects/swwf/. Standardized recordings of Southwestern Willow Flycatchers also are available online at http://www.naturesongs.com/ tyrrcert.html\#tyrr. Specifically, only fitz-bews and britts should be used for conducting surveys, to provide more robust comparative results among sites and years. 
Willow Flycatcher song rates are highest early in the breeding season (late May-early June), and typically decline after eggs hatch. However, in areas with many territorial flycatchers or where an unpaired flycatcher is still trying to attract a mate, or where re-nesting occurs, singing rates may remain high well into July. Isolated pairs can be much quieter and harder to detect than pairs with adjacent territorial flycatchers. At some sites, pre-dawn singing (03300500 hours) appears to continue strongly at least through mid-July (Sogge and others, 1995). Singing rates may increase again later in the season, possibly coinciding with re-nesting attempts (Yard and Brown, 2003). The social dynamics of adjacent territories can strongly influence vocalization rates. A single "fitz-bew" from one flycatcher may elicit multiple responses from adjacent territories. When these interactions occur, it is a good opportunity to distinguish among territories and provides the surveyor with an estimate of territory numbers in the immediate area.

There are some periods during which Willow Flycatchers do not sing and even the use of call-playback sometimes fails to elicit any response. This can be particularly true late in the breeding season. Early and repeated surveys are the best way to maximize the odds of detecting a singing flycatcher and determining its breeding status.

\section{Timing and Number of Visits}

No survey protocol can guarantee that a Southwestern Willow Flycatcher, if present, will be detected on any single visit. However, performing repeated surveys during the early to mid-nesting season increases the likelihood of detecting flycatchers and aids in determining their breeding status. A single survey, or surveys conducted too early or late in the breeding cycle, do not provide definitive data and are of limited value.

For purposes of this survey protocol, we have divided the Southwestern Willow Flycatcher breeding season into three basic survey periods, and specified a minimum number of survey visits for each period (fig. 9). Although the Sogge and others (1997a) protocol recommended a minimum of one survey in each period, we now recommend a differing number of visits for general surveys versus project-related studies.

General surveys are conducted for the sole purpose of determining whether Willow Flycatchers are present or absent from a respective site, when there is no foreseeable direct or indirect impact to their habitat from a known potential project or change in site management. In such cases, a minimum of one survey visit is required in each of the three survey periods.

Project-related surveys are conducted to determine the presence or absence of Willow Flycatchers within a site when there is a potential or foreseeable impact to their habitat due to a potential project or change in site management. Additional surveys are required for project-related studies in order to derive a greater degree of confidence regarding the presence or absence of Willow Flycatchers.
All successive surveys must be at least 5 days apart; surveys conducted more closely are not considered to be separate surveys. Although a minimum of three or five surveys are required for general and project-related purposes, respectively, if the habitat patches are large, contiguous and extremely dense, additional surveys are strongly encouraged to ensure full coverage of the site.

If you are uncertain whether three general surveys or five project-related surveys are required for your respective study, contact your USFWS flycatcher coordinator. As noted earlier, this survey protocol will help determine if territorial flycatchers are present and their approximate locations; if your project requires fine-scale estimates of flycatcher numbers or distribution at a site, you may need to conduct more intensive efforts that include additional surveys, nest searches, and nest monitoring.

Survey Period 1: May 15-31.-For both general and project-related surveys: a minimum of one survey is required. The timing of this survey is intended to coincide with the period of high singing rates in newly arrived males, which tends to begin in early to mid-May. This is one of the most reliable times to detect flycatchers that have established their territories, so there is substantial value to conducting period 1 surveys even though not all territorial males may yet have arrived. Migrant Willow Flycatchers of multiple subspecies will likely be present and singing during this period. Because both migrant and resident Willow Flycatchers are present during this period, and relatively more abundant then in subsequent surveys, it is an excellent opportunity to hone your survey and detection skills and gain confidence in your abilities. Detections of flycatchers during period 1 also provide insight on areas to pay particular attention to during the next survey period.

Survey Period 2: June 1-24.-For general surveys: a minimum of one survey is required. For project-related surveys, a minimum of two surveys are required. Note that this differs from the minimum of one survey that was recommended in this period under the previous protocol (Sogge and others, 1997a). During this period, the earliest arriving males may already be paired and singing less, but later arriving males should still be singing strongly. Period 2 surveys can provide insight about the status of any flycatchers detected during survey period 1 . For example, if a flycatcher is detected during survey period 1 but not survey period 2, the first detection may have been a migrant. Conversely, detecting a flycatcher at the same site during periods 1 and 2 increases the likelihood that the bird is not a migrant, although it does not necessarily confirm it. Survey period 2 also is the earliest time during which you are likely to find nesting activity by resident birds at most sites. Special care should be taken during this period to watch for activity that will verify whether the flycatchers that are present are attempting to breed. A little extra time and diligence should be spent at all locations where flycatchers were detected during survey period 1. 


\section{Survey Visit Timing, Numbers, and Detection Interpretation}

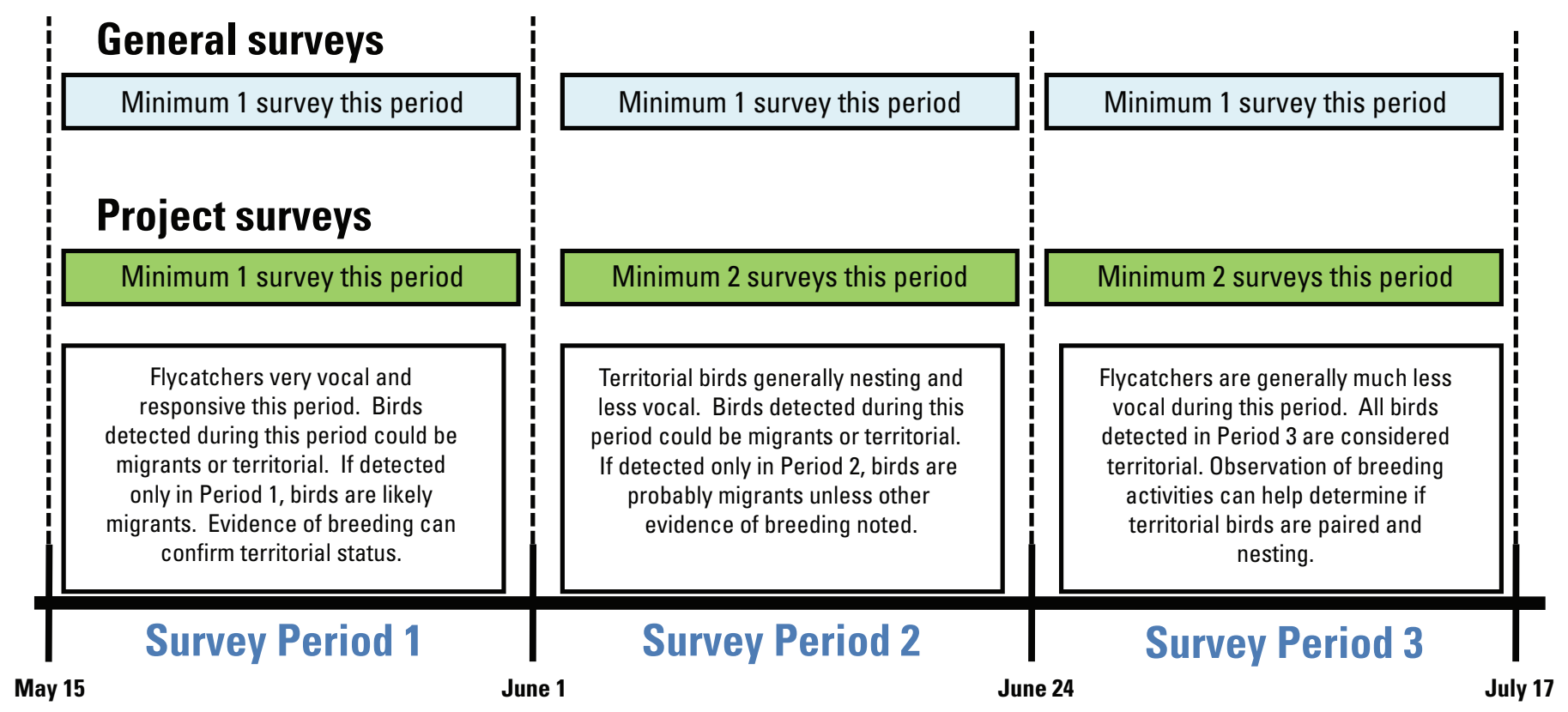

Figure 9. Recommended numbers and timing of visits during each survey period for general surveys and project surveys. General surveys are those conducted when there is no foreseeable direct or indirect impact to their habitat from a known potential project or change in site management. Project-related surveys are conducted when there is a potential or foreseeable impact to their habitat due to a potential project or change in site management.

Survey Period 3: June 25-July 17.-For general surveys, a minimum of one survey is required. For project-related surveys, a minimum of two surveys are required. Virtually all Southwestern Willow Flycatchers should have arrived on their territories by this time. Flycatcher singing rates probably have lessened, and most paired flycatchers will have initiated or even completed their first round of nesting activity. Migrant Willow Flycatchers should no longer be passing through the Southwest; therefore, any flycatchers that you detect are likely to be either territorial or nonbreeding floaters. Surveyors should determine if flycatchers detected during surveys in periods 1 or 2 are still present, and watch closely for nesting activity. Flycatchers that have completed a first nesting attempt may resume vigorous singing during this period. Extra time and diligence should be spent at all locations where flycatchers were detected during survey periods 1 or 2 .

At high elevation sites (above 2,000 m), Southwestern Willow Flycatcher arrival and initiation of breeding activities may occur in early June, and possibly later in some years due to weather or migration patterns. Therefore, flycatcher breeding chronology may be delayed by 1 or 2 weeks at such sites, and surveys should be conducted in the latter part of each period.
It may not require multiple surveys to verify Southwestern Willow Flycatcher presence or breeding status. If, for example, Willow Flycatchers are observed carrying nest material during survey periods 1 or 2 , this is conclusive verification they are breeders as opposed to migrants, regardless of what is found during period 3. However, it requires a minimum of three surveys for general studies and five surveys for project-related studies to determine with relative confidence that Southwestern Willow Flycatchers probably are not breeding at a site in that year, based on lack of detections.

We strongly encourage additional follow-up surveys to sites where territorial Southwestern Willow Flycatchers are verified or suspected. Extra surveys provide greater confidence about presence or absence of flycatchers at a site, as well as help in estimating the number of breeding territories or pairs, and determining breeding status and the outcome of breeding efforts. Pre-survey visits the evening before the survey or post-survey follow-up later in the morning can help confirm breeding status when surveyors are not under time constraints. However, avoid returning to a site so often as to damage the habitat, establish or enlarge trails, or cause undue disturbance to the flycatchers. 


\section{Survey Methods}

The survey methods described below fulfill the primary objectives of documenting the presence or absence of Willow Flycatchers, and determining their status as territorial versus migrant. This protocol primarily is a call-playback technique, a proven method for eliciting response from nearby Willow Flycatchers (Seutin, 1987; Craig and others, 1992), both territorial and migrants. The premise of the call-playback technique is to simulate a territorial intrusion by another Willow Flycatcher, which generally will elicit a defensive response by the territorial bird, increasing its detectability. At each site, surveyors should broadcast a series of recorded Willow Flycatcher fitz-bews and britts, and look and listen for responses. In addition to maximizing the likelihood of detecting nearby flycatchers, this method also allows for positive identification by comparing the responding bird's vocalizations to the known Willow Flycatcher recording.

Documenting Presence/Absence-Begin surveys as soon as there is enough light to safely walk (about 1 hour before sunrise) and end by about 0900-1030 hours, depending on the temperature, wind, rain, background noise, and other environmental factors. Use your best professional judgment whether to conduct surveys that day based on local field conditions. If the detectability of flycatchers is being reduced by environmental factors, surveys planned for that day should be postponed until conditions improve. If observers are camped in or near potential Willow Flycatcher habitat, afternoons and evenings can be spent doing site reconnaissance and planning a survey strategy for the following morning. If camped immediately adjacent to survey sites, surveyors can awaken early and listen for flycatchers singing during the predawn period (0330-0500 hours), when territorial males often sing loudly.

Conduct surveys from within rather than from the perimeter of the sites, while limiting the breaking of vegetation or damaging the habitat. If surveys cannot be conducted from within the habitat, walk along the perimeter and enter the patch at intervals to broadcast the vocalizations and listen for responses. Flycatchers often respond most strongly if the recording is played from within the habitat and territory, rather than from the periphery. In addition, it can be surprisingly difficult to hear singing Willow Flycatchers that are even a short distance away amidst the noise generated by other singing and calling birds, roads, noisy streams, and other extraneous sounds. Therefore, it is preferable to survey from within the habitat, but always move carefully to avoid disturbing habitat or nests. Surveying from the periphery should not be conducted only for the sake of convenience, but is allowable for narrow linear reaches or when absolutely necessary due to safety considerations.

Because flycatchers may be clustered within only a portion of a habitat patch, it is critical to survey all suitable habitat within the patch. Small linear sites may be thoroughly covered by a single transect through the patch. For larger sites, choose a systematic survey path that assures complete patch coverage throughout the length and breadth of the site. This may require multiple straight transects, serpentine, zig-zag, or criss-cross routes. Aerial photographs and previous survey forms are valuable tools to help plan and conduct surveys, and to assure complete coverage. Always move carefully through the habitat to avoid disturbing vegetation or nests.

Initially approach each site and stand quietly for 1-2 minutes or longer, listening for spontaneously singing flycatchers. A period of quiet listening is important because it helps acclimate surveyors to background noises that can be quite loud due to roads, aircraft, machinery, waterways, and other sounds. It also allows surveyors to recognize and shift attention away from the songs and calls of other bird species, letting them focus on listening for flycatchers. Although it happens rarely, some singing Willow Flycatchers will actually stop vocalizing and approach quietly in response to a broadcast song, perhaps in an effort to locate what they perceive as an intruding male. Therefore, playing a recording before listening for singing individuals has at least some potential of reducing detectability.

If you do not hear singing flycatchers during the initial listening period, broadcast the Willow Flycatcher song recording for 10-15 seconds; then listen for approximately 1 minute for a response. Repeat this procedure (including a 10-second quiet pre-broadcast listening period) every $20-30 \mathrm{~m}$ throughout each survey site, more often if background noise is loud. The recording should be played at about the volume of natural bird calls, and not so loud as to cause distortion of the broadcast. We recommend that the playback recording include a series of fitz-bews interspersed with several britts.

Response to the broadcast call could take several forms. Early in the breeding season (approximately May-mid-June), a responding Willow Flycatcher will usually move toward the observer and fitz-bew or whitt from within or at the top of vegetation. Territorial Willow Flycatchers almost always vocalize strongly when a recording is played in their territory early in the season. If there are several flycatchers present in an area, some or all may start singing after hearing the recording or the first responding individual. Flycatchers can often hear the recording from far away but will not usually move outside of their territory, so listen for distant responses. Also, stay alert and listen for flycatchers vocalizing behind you that may not have responded when you were first in their territory. Another common flycatcher response is alarm calls (whitts) or interaction twitters from within nearby vegetation, particularly once nesting has begun. Willow Flycatchers will often sing after a period of whitting in response to a recording, so surveyors hearing whitts should remain in the area and quietly listen for fitz-bews for several minutes. Because some flycatchers may initially respond by approaching quietly, particularly during periods 2 and 3 , it is critical to watch carefully for responding birds. 
If you detect flycatchers that appear particularly agitated, it is possible that you are in close proximity to their nest. Agitated flycatchers may swoop down at the surveyor, snap their beaks, and otherwise appear distressed. Exercise extreme caution so as to not accidently disturb the nest, and move slowly away from the immediate area.

For the purpose of this protocol, detection of a fitz-bew song is essential to identify a bird as a Willow Flycatcher. Similar appearing species (including other Empidonax flycatchers) occur as migrants, and even breeders, at potential Willow Flycatcher sites. A few of these other species may even approach a broadcast Willow Flycatcher song and respond with vocalizations. In order to standardize interpretation of survey results and assure a high degree of confidence in surveys conducted by biologists of varying experience and skill, positive identification must be based on detection of the Willow Flycatcher's most unique characteristic - its song. It is important to remember that the whitt call is not unique to Willow Flycatchers, and therefore cannot serve as the basis of a positive identification. However, whitts are extremely useful for locating flycatchers and identifying areas needing follow-up visits. Loud, strong whitting may indicate a nearby nest, dictating that surveyors exercise extra caution moving through the area.

Whenever a verified or suspected Willow Flycatcher is detected, be careful not to overplay the song recording. Excessive playing could divert the bird from normal breeding activities or attract the attention of predators and brood parasites. Wildlife management agencies may consider overplaying the recording as "harassment" of the flycatcher, and this is not needed to verify species identification.

Although flycatchers usually sing repeatedly once prompted, even a single fitz-bew is sufficient for verification. If you have played a recording several times and a bird has approached but has not fitz-bewed, do not continue playing the recording. If a potential Willow Flycatcher responds, approaches or whitts but does not sing, it is best to carefully back away and wait quietly. If it is a Willow Flycatcher, it probably will sing within a short time (5-10 minutes). Another option is to return to the same site early the following morning to listen for or attempt to elicit singing again. If you are still uncertain, record the location with your GPS, record comments on the survey form, and follow-up on the detection during subsequent surveys. If possible, request the assistance of an experienced surveyor to determine positive identification.

If more habitat remains to be surveyed, continue onward once a flycatcher is detected and verified. In doing so, move 30-40 m past the current detection before again playing the recording, and try to avoid double-counting flycatchers that have already responded. Willow Flycatchers, particularly unpaired males, may follow the broadcast song for $50 \mathrm{~m}$ or more.
Looking For and Recording Color Bands.-Several research projects have involved the capture and banding of Willow Flycatchers at breeding sites across the Southwest. In such projects, flycatchers are banded with one or more small colored leg bands, including a federal numbered band. As a result, surveyors may find color-banded individuals at their survey sites, and identification and reporting of the band combination can provide important data on flycatcher movements, survivorship, and site fidelity.

To look for bands, move to get a good view of the flycatcher's legs. This may be difficult in dense vegetation, but flycatchers commonly perch on more exposed branches at the edges of their territory or habitat patch. If bands are seen, carefully note the band colors. If there is more than one band on a leg, differentiate the top (farthest up the leg) from the bottom (closest to the foot), and those on the bird's left leg versus the right leg. If you are unsure of the color, do not guess. Instead, record the color as unknown. Incorrect color-band data are worse than incomplete data, so only record colors of which you are certain. The fact that a banded bird was seen, even without being certain of its color combination, is very important information. Record the color-band information on the survey form, and report the sighting to the appropriate State or Federal contact as soon as you return from the survey that day.

\section{Determining the Number of Territories and Pairs. -}

Accurately determining the number of breeding territories and pairs can be more difficult than determining simple presence or absence. Flycatcher habitat is usually so dense that visual detections are difficult, and seeing more than one bird at a time is often impossible. Flycatchers sing from multiple song perches within their territories, and may be mistaken for more than one flycatcher. A flycatcher responding to or following a surveyor playing a recording may move considerable distances in a patch and thus be counted more than once. Territorial male flycatchers often sing strongly, but so do many migrants and some females, particularly in response to call-playback (Seutin, 1987; Unitt, 1987; Sogge and others, 1997b). Rangewide, many territorial male flycatchers are unmated, particularly those in small breeding groups. For these reasons, each singing flycatcher may not represent a territory or a mated pair. Following the established survey protocol and carefully observing flycatcher behavior can help determine if you have detected migrants, territorial birds, breeders, unmated birds, or pairs.

Given sufficient time, effort and observation, it is usually possible to approximate the number of territories and pairs. First, listen carefully for simultaneously singing flycatchers. Note the general location of each bird - especially concurrently singing individuals_on aerial photographs, map, or a site sketch. Spend some time watching each flycatcher to determine approximate boundaries of its territory, and how it interacts with other flycatchers. If one or more singing 
birds stay primarily in mutually exclusive areas, they can be considered as separate territories. To determine if a flycatcher is paired, watch for interactions within a territory. Refer to the section, "Determining Breeding Status" for signs of pairing and breeding activity. Do not report a territorial male as a pair unless you observe one or more of the signs listed below. In some cases, it may be possible only to estimate the number of singing individuals. In other cases, it may take multiple site visits to differentiate territories or pairs.

Determining Breeding Status.-One way to determine if the flycatchers found at a particular site are migrants or territorial is to find out if they are still present during the "non-migrant" period, which generally is from about June 15 to July 20 (Unitt, 1987). A Willow Flycatcher found during this time probably is a territorial bird, although there is a small chance it could be a non-territorial floater (Paxton and others, 2007). If the management question is simply whether the site is a potential breeding area, documenting the presence of a territorial flycatcher during the non-migrant period may meet all survey objectives, and the site may not need to be resurveyed during the remainder of that breeding season.

However, in some cases, surveyors will be interested in knowing not only if territorial Southwestern Willow Flycatchers are present at a site, but also whether breeding or nesting efforts are taking place. Some males maintain territories well into July yet never succeed in attracting a mate, so unpaired males are not uncommon (McLeod and others, 2007; Ellis and others, 2008; Ahlers and Moore, 2009). Thus, an assumption that each singing male represents a breeding pair may not be well founded, especially in small populations. If it is important to determine whether a pair is present and breeding in that territory, move a short distance away from where the bird was sighted, find a good vantage point, and sit or lie quietly to watch for evidence of breeding. Signs of breeding activity include:

a. observation of another unchallenged Willow Flycatcher in the immediate vicinity (indicates possible pair);

b. whitt calls between nearby flycatchers (indicates possible pair);

c. interaction twitter calls between nearby flycatchers (indicates possible pair);

d. countersinging or physical aggression against another flycatcher or bird species (suggests territorial defense);

e. physical aggression against cowbirds (suggests nest defense);

f. observation of Willow Flycatchers copulating (verifies attempted breeding);

g. flycatcher carrying nest material (verifies nesting attempt, but not nest outcome);

h. flycatcher carrying food or fecal sac (verifies nest with young, but not nest outcome);

i. locating an active nest (verifies nesting). Recall that general survey permits do not authorize nest searching or monitoring, and see section, "Special Considerations"; j. observation of adult flycatchers feeding fledged young (verifies successful nesting).

You may be able to detect flycatcher nesting activity, especially once the chicks are being fed. Adults feed chicks at rates of as many as 30 times per hour, and the repeated trips to the nest tree or bush are often quite evident. Be sure to note on the flycatcher survey form any breeding activity that is observed, including detailed descriptions of the number of birds, and specific activities observed. Also note the location of breeding activities on an aerial photograph, map, or sketch of the area.

The number of flycatchers found at a site also can provide a clue as to whether they are migrants or territorial birds. Early season detections of single, isolated Willow Flycatchers often turn out to be migrants. However, discovery of a number of Willow Flycatchers at one site usually leads to verification that at least some of them remain as local breeders. This underscores the importance of completing a thorough survey of each site to be confident of the approximate number of flycatchers present.

In some cases, regardless of the time and diligence of your efforts, it will be difficult to determine the actual breeding status of a territorial male. In these instances, use your best professional judgment, or request the assistance of an experienced surveyor or an agency flycatcher coordinator to interpret your observations regarding breeding status.

Reporting Results.- There is little value in conducting formal surveys if the data are not recorded and submitted. Fill in all appropriate information on the Willow Flycatcher survey form while still in the field, and mark the location of detections on a copy of the USGS topographic map. Make a habit of reviewing the form before you leave any site-trying to remember specific information and recording it later can lead to missing and inaccurate data. Note the location of the sighting on an aerial photograph or sketch of the site. Attaching photographs of the habitat also is useful. Whenever a Willow Flycatcher territory or nest site is confirmed, notify the USFWS or appropriate State wildlife agency as soon as you return from the field. The immediate reporting of flycatcher detections or nests may differ among USFWS regions and States-discuss these reporting procedures with your respective State and USFWS flycatcher coordinators.

Complete a survey form (appendix 1) for each site surveyed, whether or not flycatchers are detected. "Negative data" (that is, a lack of detections) are important to document the absence of Willow Flycatchers and help determine what areas have already been surveyed. Make and retain a copy of each survey form, and submit the original or a legible copy. Electronic copies of the survey forms also are acceptable and are available online (http://sbsc.wr.usgs.gov/cprs/research/ projects/swwf/). All survey forms must be submitted to the USFWS and the appropriate State wildlife agency by the specified deadline identified in your permits. Timely submission of survey data is a permit requirement, and will ensure the information is included in annual statewide and regional reports. 


\section{Special Considerations}

To avoid adverse impacts to Willow Flycatchers, follow these guidelines when performing all surveys:

1. Obtain all necessary Federal, State, and agency permits and permissions prior to conducting any surveys. Failure to do so leaves you liable for violation of the Endangered Species Act, various State laws, and prosecution for trespass.

2. Do not play the recording more than necessary or needlessly elicit vocal responses once Willow Flycatchers have been located and verified. This may distract territorial birds from caring for eggs or young, or defending their territory. If flycatchers are vocalizing upon arrival at the site, and your objective is to determine their presence or absence at a particular site - there is no need to play the recording. Excessive playing of the recording also may attract the attention of predators or brood parasites. Stop playing the survey recording as soon as you have confirmed the presence of a Willow Flycatcher, and do not play the recording again until you have moved $30-40 \mathrm{~m}$ to the next survey location.

3. Proceed cautiously while moving through Willow Flycatcher habitat. Continuously check the area around you to avoid disturbance to nests of Willow Flycatchers and other species. Do not break understory vegetation, even dead branches, to create a path through the surveyed habitat.

4. Do not approach known or suspected nests. Nest searches and monitoring require specific State and Federal permits, have their own specialized methodologies (Rourke and others, 1999), and are not intended to be a part of this survey protocol.

5. If you find yourself close to a known or suspected nest, move away slowly to avoid startling the birds or force-fledging the young. Avoid physical contact with the nest or nest tree, to prevent physical disturbance and leaving a scent. Do not leave the nest area by the same route that you approached. This leaves a "dead end" trail that could guide a potential predator to the nest/nest tree. If nest monitoring is a component of the study, but you are not specifically permitted to monitor the nest, store a waypoint with your GPS, affix flagging to a nearby tree at least $10 \mathrm{~m}$ away, and record the compass bearing to the nest on the flagging. Report your findings to an agency flycatcher coordinator or a biologist who is permitted to monitor nests.

6. If you use flagging to mark an area where flycatchers are found, use it conservatively and make certain the flagging is not near an active nest. Check with the property owner or land-management agency before flagging to be sure that similar flagging is not being used for other purposes in the area. Unless conducting specific and authorized/ permitted nest monitoring, flagging should be placed no closer than $10 \mathrm{~m}$ to any nest. Keep flagging inconspicuous from general public view to avoid attracting people or animals to an occupied site, and remove it at the end of the breeding season.

7. Watch for and note the presence of potential nest predators, particularly birds, such as Common Ravens (Corvus corax), American Crows (Corvus brachyrhynchos), jays, and magpies. If such predators are in the immediate vicinity, wait for them to leave before playing the recording.

8. Although cowbird parasitism is no longer considered among the primary threats to flycatcher conservation it remains useful to note high concentrations of cowbirds in the comment section of the survey form. While conducting surveys, avoid broadcasting the flycatcher vocalizations if cowbirds are nearby, especially if you believe you may be close to an active flycatcher territory. The intent of not broadcasting flycatcher vocalizations is to reduce the potential for attracting cowbirds to a flycatcher territory or making flycatcher nests more detectable to cowbirds.

9. Non-indigenous plants and animals can pose a significant threat to flycatcher habitat and may be unintentionally spread by field personnel, including those conducting flycatcher surveys. Simple avoidance and sanitation measures can help prevent the spread of these organisms to other environments. To avoid being a carrier of non-indigenous plants or animals from one field site to another visually inspect and clean your clothing, gear, and vehicles before moving to a different field site. A detailed description on how to prevent and control the spread of these species is available by visiting the Hazard Analysis and Critical Control Point Planning for Natural Resource Management web site (http://www.haccp-nrm. org). One species of particular interest is the tamarisk leaf-beetle (Diorhabda spp.). If you observe defoliation of saltcedar while conducting flycatcher surveys and believe that Diorhabda beetles may be responsible, notify your USFWS coordinator immediately. Other non-native species of concern in survey locations are the quagga mussel (Dreissena rostriformis bugensis), cheatgrass (Bromus tectorum), red brome (Bromus rubens), giant salvinia (Salvinia molesta), water milfoil (Myriophyllum spicatum), parrot's feather (M. aquaticum), and amphibian chytrid fungus (Batrachochytrium dendrobatidis). 


\section{Acknowledgments}

The authors' work on this protocol was supported by the U.S. Geological Survey, the Bureau of Reclamation, and the U.S. Fish and Wildlife Service. We are indebted to numerous colleagues who over the years provided feedback on the previous survey protocols and helped shape this current revision; in particular we thank Allen Graber, William Haas, Tom Koronkiewicz, Barbara Kus, Henry Messing, Theresa Olson, Chuck Paradzick, Ruth Valencia, Mary Whitfield, and Sartor O. Williams, III. Greg Beatty, Peter Beck, Nathan Darnel, Robert Doster, Gjon Hazard, Ronald Kirby, Eben Paxton, Linda Sogge, and Leilani Takano provided helpful feedback on early drafts of this document. Eben Paxton also provided assistance with graphics. Revisions to the survey forms were a culmination of recommendations from many surveyors and data compilers. We especially thank Francoise Leonard, Shay Stump, Heather English, Barbara Kus, Scott Durst, Hira Walker, Greg Beatty, and Dave Moore for providing their insight from years of experience collecting data and interpreting field forms. We are especially grateful to Greg Beatty for his support of our efforts and for the key role he has played in helping standardize Southwestern Willow Flycatcher survey efforts across the Southwest.

\section{References Cited}

Ahlers, D., and White, L., 2000, 1999 Willow Flycatcher survey results: Fish Creek and Gooseberry Creek drainages, Utah: Report by the Bureau of Reclamation, Technical Service Center, Denver, Colorado.

Ahlers, D., and Moore, D., 2009, A review of vegetation and hydrologic parameters associated with the Southwestern Willow Flycatcher - 2002-2008, Elephant Butte Reservoir Delta, NM: Report by the Bureau of Reclamation, Technical Service Center, Denver, Colorado.

Allison, L.J., Paradzick, C.E., Rourke, J.W., and McCarthey, T.C., 2003, A characterization of vegetation in nesting and non-nesting plots for Southwestern Willow Flycatchers in central Arizona: Studies in Avian Biology, v. 26, p. 81-90.

Arizona Game and Fish Department, 2006, DRAFT, Arizona's Comprehensive Wildlife Conservation Strategy-2005-2015: Arizona Game and Fish Department, Phoenix, Arizona. (Also available at http://www.azgfd.gov/pdfs/w c/cwcs/ downloads/CWCS Final May2006.pdf.)

Bibby, C.J., Burgess, N.D., and Hill, D.A., 1992, Bird census techniques: Academic Press, London, U.K.

Browning, M.R., 1993, Comments on the taxonomy of Empidonax traillii (Willow Flycatcher): Western Birds, v. 24, p. 241-257.
Busch, J.D., Miller, M.P., Paxton, E.H., Sogge, M.K., and Keim, P., 2000, Genetic variation in the endangered Southwestern Willow Flycatcher: Auk, v. 117, p. 586-595.

California Department of Fish and Game, 1991, Endangered and threatened animals of California: State of California, The Resources Agency, Department of Fish and Game, Sacramento, California, 5 p.

Cardinal, S.N., Paxton, E.H., and Durst, S.L., 2006, Home range, movement, and habitat use of the Southwestern Willow Flycatcher, Roosevelt Lake, AZ—2005: U.S. Geological Survey report to the Bureau of Reclamation, Phoenix, AZ, 21 p.

Craig, D., Schlorff, R.W., Valentine, B.E., and Pelles, C., 1992, Survey protocol for Willow Flycatchers (Empidonax traillii) on National Forest Service lands in the Pacific Southwest region: U.S. Forest Service Region 5, Vallejo, CA.

Dahl, T.E., 1990, Wetlands losses in the United States, 1780s to 1980s: U.S. Department of the Interior, Fish and Wildlife Service, Washington, D.C., 13 p.

Davidson, R.F., and Allison, L.J., 2003, Effects of monogamy and polygyny on reproductive success in Southwestern Willow Flycatchers (Empidonax traillii extimus) in Arizona: Studies in Avian Biology, v. 26, p. 118-124.

DeLay, L.S., Stoleson, S.H., and Farnsworth M., 2002, A quantitative analysis of the diet of Southwestern Willow Flycatchers in the Gila Valley, New Mexico: Final report to T\&E Inc., accessed July 28, 2008, at http://sbsc.wr.usgs. gov/cprs/research/projects/swwf/Reports/NM SWWF Diet Report 2002.pdf.

DeLoach, C.J., Carruthers, R.I., Lovich, J., Dudley, T.L., and Smith, S.D., 2000, Ecological interactions in the biological control of saltcedar (Tamarix spp.) in the U.S.: Toward a new understanding, in Spencer, N.R., ed., Proceedings of $\mathrm{X}$ International Symposium on Biological Control, July 1999, Montana State University, Bozeman, p. 819-874.

Drost, C.A., Paxton, E.H., Sogge, M.K., and Whitfield, M.J., 2003, Food habits of the Southwestern Willow Flycatcher at the Kern River, California: Studies in Avian Biology, v. 26, p. 96-103.

Dudley, T.L., and DeLoach, C.J., 2004, Saltcedar (Tamarix spp.), endangered species, and biological weed controlcan they mix?: Weed Technology, v. 18, p. 1542-1551.

Durst, S.L., 2004, Southwestern Willow Flycatcher potential prey base and diet in native and exotic habitats: Flagstaff, Arizona, Northern Arizona University, M.S. Thesis, 86 p. 
Durst, S.L., Theimer, T.C., Paxton, E.H., and Sogge, M.K., 2008a, Age, habitat, and yearly variation in the diet of a generalist insectivore, the Southwestern Willow Flycatcher: Condor, v. 110, p. 514-525.

Durst, S.L., Sogge, M.K., Stump, S.D., Walker, H.A., Kus, B.E., and Sferra S.J., 2008b, Southwestern Willow Flycatcher breeding sites and territory summary_2007: U.S. Geological Survey Open-File Report 2008-1303, 31 p. (Also available at http://pubs.usgs.gov/of/2008/1303.)

Ellis, L.A., Weddle, D.M., Stump, S.D., English, H.C., and Graber, A.E., 2008, Southwestern Willow Flycatcher final survey and monitoring report: Arizona Game and Fish Department, Research Technical Guidance Bulletin \#10, Phoenix, Arizona, USA.

Finch, D.M., Kelly, J.F., and Cartron, J.E., 2000, Chapter 7: Migration and Winter Ecology, in Finch, D.M., and Stoleson, S.H., eds., Status, ecology, and conservation of the Southwestern Willow Flycatcher: U.S. Forest Service Rocky Mountain Research Station General Technical Report-60, p. 71-82.

General Accounting Office, 1988, Public rangelands: Some riparian areas restored but widespread improvement will be slow: General Accounting Office, U.S. Government, Washington, D.C.

Graf, W.L., Stromberg, J., and Valentine, B., 2002, Rivers, dams, and Willow Flycatchers: A summary of their science and policy connections: Geomorphology, v. 47, p. 169-188.

Haas, W.E., 2003, Southwestern Willow Flycatcher field season 2002 data summary: Varanus Biological Services, Inc., San Diego, CA.

Harris, J.H., 1991, Effects of brood parasitism by Brown-headed Cowbirds on Willow Flycatcher nesting success along the Kern River, California: Western Birds, v. 22, no. 1, p. 13-26.

Hatten, J.R., and Paradzick, C.E., 2003, A multiscaled model of Southwestern Willow Flycatcher breeding habitat: Journal of Wildlife Management, v. 67, p. 774-788.

Hatten, J.R., and Sogge, M.K., 2007, Using a remote sensing/ GIS model to predict Southwestern Willow Flycatcher breeding habitat along the Rio Grande, New Mexico: U.S. Geological Survey Open-File Report 2007-1207, 27 p. (Also available at http://pubs.usgs.gov/of/2007/1207.)

Hubbard, J.P., 1987, The status of the Willow Flycatcher in New Mexico: Endangered Species Program, New Mexico Department of Game and Fish, Santa Fe, New Mexico, 29 p.

Hubbard, J.P., 1999, A critique of Wang Yong and Finch's field-identifications of Willow Flycatcher subspecies in New Mexico: Wilson Bulletin, v. 11, p. 585-588.
Koronkiewicz, T.J., 2002, Intraspecific territoriality and site fidelity of wintering Willow Flycatchers (Empidonax traillii) in Costa Rica: Flagstaff, Arizona, Northern Arizona University, M.S. thesis, 73 p.

Koronkiewicz, T.J., and Sogge, M.K., 2000, Willow Flycatcher (Empidonax traillii) winter ecology studyCosta Rica 1999/2000: U.S. Geological Survey, Forest and Rangeland Ecosystem Science Center/Colorado Plateau Research Station report.

Koronkiewicz, T.J., McLeod, M.A., Brown, B.T., and Carothers, S.W., 2006a, Southwestern Willow Flycatcher surveys, demography, and ecology along the lower Colorado River and tributaries, 2005: Annual report submitted to Bureau of Reclamation, Boulder City, NV by SWCA Environmental Consultants, Flagstaff, AZ.

Koronkiewicz, T.J., Sogge, M.K., van Riper, C., and Paxton, E.H., 2006b, Territoriality, site fidelity, and survivorship of Willow Flycatchers Wintering in Costa Rica: Condor, v. 108 , p. 558-570.

Koronkiewicz, T.J., and Whitfield, M.J., 1999, Winter ecology of the Southwestern Willow Flycatcher: San Diego Natural History Museum and Kern River Research Center report.

Kus, B.E., Beck, P.P., and Wells, J.M., 2003, Southwestern Willow Flycatcher populations in California: distribution, abundance, and potential for conservation: Studies in Avian Biology, v. 26, p. 12-21.

Lynn, J.C., Koronkiewicz, T.J., Whitfield M.J., and Sogge, M.K., 2003, Willow Flycatcher winter habitat in El Salvador, Costa Rica, and Panama-Characteristics and threats: Studies in Avian Biology, v. 26, p. 41-51.

Marshall, R.M., and Stoleson, S.H., 2000_Chapter 3: Threats, in Finch, D.M., and Stoleson, S.H., eds., Status, ecology, and conservation of the Southwestern Willow Flycatcher: U.S. Forest Service Rocky Mountain Research Station General Technical Report-60, p. 13-24.

Maynard, W.R., 1995, Summary of 1994 survey efforts in New Mexico for Southwestern Willow Flycatcher (Empidonax traillii extimus): New Mexico Department of Game and Fish, Santa Fe, NM, Contract \#94-516-69, 48 p.

McLeod, M.A., Koronkiewicz, T.J., Brown, B.T., and Carothers, S.W., 2007, Southwestern Willow Flycatcher surveys, demography, and ecology along the lower Colorado River and tributaries, 2006: Annual report submitted to Bureau of Reclamation, Boulder City, Nevada by SWCA Environmental Consultants, Flagstaff, AZ, 194 p.

Moore, D., 2005, Status and monitoring of Southwestern Willow Flycatchers within Elephant Butte Reservoir, New Mexico: Report by the Bureau of Reclamation, Technical Service Center, Denver, Colorado. 
Moore, D., 2007, Vegetation quantification of Southwestern Willow Flycatcher nest sites: Rio Grande from La Joya to Elephant Butte Reservoir Delta, New Mexico, 2004-2006: Bureau of Reclamation, Technical Service Center, Denver, CO.

Moore, D., and Ahlers, D., 2009, 2008 Southwestern Willow Flycatcher study results: selected sites along the Rio Grande from Velarde to Elephant Butte Reservoir, New Mexico: Report by the Bureau of Reclamation, Technical Service Center, Denver, Colorado.

Munzer, O.M., English, H.C., Smith, A.B., and Tudor A.A., 2005, Southwestern Willow Flycatcher 2004 survey and nest monitoring report: Nongame and Endangered Wildlife Program Technical Report 244, Arizona Game and Fish Department, Phoenix, Arizona, 73 p.

New Mexico Department of Game and Fish, 1996, List of threatened and endangered: Amendment No. 1, NMAC 33.1; 31 January 1996: New Mexico Department of Game and Fish, Santa Fe, New Mexico.

Nishida, C., and Whitfield, M.J., 2007, Winter distribution of the Willow Flycatcher (Empidonax traillii) in Ecuador and Northern Mexico: Report to the Bureau of Reclamation, Boulder City, NV.

Owen, J.C., Sogge, M.K., and Kern, M.D., 2005, Habitat and gender differences in the physiological condition of breeding Southwestern Willow Flycatchers: Auk, v. 122, no. 4, p. 1261-1270.

Paradzick, C.E., and Woodward, A.A., 2003, Distribution, abundance, and habitat characteristics of Southwestern Willow Flycatchers (Empidonax traillii extimus) in Arizona, 1993-2000: Studies in Avian Biology, v. 26, p. 22-29.

Paxton, E.H., 2000, Molecular genetic structuring and demographic history of the Willow Flycatcher: Flagstaff, Arizona, Northern Arizona University, MS thesis, 43 p.

Paxton, E.H., 2008, Geographic variation and migratory connectivity of Willow Flycatcher subspecies: Flagstaff, Arizona, Northern Arizona University, Ph.D. dissertation, $100 \mathrm{p}$.

Paxton, E.H., and Owen, J.C., 2002, An aging guide for Willow Flycatcher nestlings: Flagstaff, Arizona, Colorado Plateau Field Station, Northern Arizona University, 18 p.

Paxton, E.H., Sogge, M.K., Durst, S.L., Theimer, T.C., and Hatten, J.R., 2007, The ecology of the Southwestern Willow Flycatcher in central Arizona-a 10-year synthesis report: U.S. Geological Survey Open-File Report 2007-1381, 143 p.
Pearson, T., Whitfield, M.J., Theimer, T.C., and Keim P., 2006, Polygyny and extra-pair paternity in a population of Southwestern Willow Flycatchers: Condor, v. 108, p. 571-578.

Phillips, A.R., 1948, Geographic variation in Empidonax traillii: Auk, v. 65, p. 507-514.

Phillips, A.R., Marshall, J., and Monson, G., 1964, The birds of Arizona: Tucson, Arizona, University of Arizona Press, 212 p.

Pulliam, H.R., 1988, Sources, sinks, and population regulation: American Naturalist, v. 132, p. 652-661.

Bureau of Reclamation, 2009, Elephant Butte Reservoir fiveyear operational plan-Biological Assessment: Bureau of Reclamation, Albuquerque Area Office, Albuquerque, NM.

Rourke, J.W., McCarthey, T.D., Davidson, R.F., and Santaniello, A.M., 1999, Southwestern Willow Flycatcher nest monitoring protocol: Nongame and Endangered Wildlife Program Technical Report 144, Arizona Game and Fish Department, Phoenix, Arizona.

Rothstein, S.I., Kus, B.E., Whitfield, M.J., and Sferra S.J., 2003, Recommendations for cowbird management in recovery efforts for the Southwestern Willow Flycatcher: Studies in Avian Biology, v. 26, p. 157-167.

Schuetz, J.G., and Whitfield, M.J., 2007, Southwestern Willow Flycatcher monitoring and removal of Brown-headed Cowbirds on the South Fork Kern River in 2006: Report to the U.S. Army Corps of Engineers, Sacramento, CA.

Schuetz, J.G., Whitfield, M.J., and Steen V.A., 2007, Winter distribution of the Willow Flycatcher (Empidonax traillii) in Guatemala and Mexico: Report by the Southern Sierra Research Station, Weldon, California.

Seager, R., Ting, M., Held, I., Kushnir, Y., Lu, J., Vecchi, G., Huang, H., Harnik, N., Leetma, A., Lau, N., Li, C., Velez, J., and Naik N., 2007, Model projections of an imminent transition to a more arid climate in southwestern North America: Science Express, April 5, 2007.

Sedgwick, J.A., 2000, Willow Flycatcher (Empidonax traillii), in Poole, A., and Gill, F., eds., The Birds of North America, No. 533: The Birds of North America, Inc., Philadelphia, Pennsylvania.

Sedgwick, J.A., 2001, Geographic variation in the song of Willow Flycatchers-Differentiation between Empidonax traillii adastus and E.t. extimus: Auk, v. 118, p. 366-379.

Seutin, G., 1987, Female song in Willow Flycatchers (Empidonax traillii): Auk, v. 104, p. 329-330. 
Sferra, S.J., Corman, T.E., Paradzick, C.E., Rourke, J.W., Spencer, J.A., and Sumner, M.W., 1997, Arizona Partners in Flight Southwestern Willow Flycatcher survey-1993-1996 summary report: Nongame and Endangered Wildlife Program Technical Report 113, Arizona Game and Fish Department, Phoenix, Arizona, 46 p.

Shook, R.S., Stoleson, S.H., and Boucher, P., 2003, A field evaluation of the Southwestern Willow Flycatcher survey protocol: Studies in Avian Biology, v. 26, p. 177-179.

Siegle, R., and Ahlers, D., 2004, Brown-headed Cowbird management techniques manual: Techniques Manual by the Bureau of Reclamation, Technical Service Center, Denver, Colorado.

Sogge, M.K., Koronkiewicz, T.J.; van Riper, C., and Durst, S.L., 2007a, Willow Flycatcher nonbreeding territory defense behavior in Costa Rica: Condor, v. 109, p. 475-480.

Sogge, M.K., Kus, B.E., Sferra, S.J., and Whitfield, M.J., 2003b, Ecology and conservation of the Willow Flycatcher-Studies in Avian Biology 26: Cooper Ornithological Society, Camarillo, CA, 210 p.

Sogge, M.K., and Marshall, R.M., 2000, Chapter 5: A survey of current breeding habitats, in Finch, D.M., and Stoleson, S.H., eds., Status, ecology, and conservation of the Southwestern Willow Flycatcher: U.S. Forest Service Rocky Mountain Research Station General Technical Report-60, p. 43-56.

Sogge, M.K., Marshall, R.M., Tibbitts, T.J., and Sferra, S.J. 1997a, A Southwestern Willow Flycatcher natural history summary and survey protocol: National Park Service Technical Report NPS/NAUCPRS/NRTR-97/12, 37 p.

Sogge, M.K., Paxton, E.H., and Tudor, A.A., 2006, Saltcedar and Southwestern Willow Flycatchers: lessons from long-term studies in central Arizona, in Aguirre-Bravo, C., Pellicane, P.J., Burns, D.P., and Draggan, S., eds., Monitoring science and technology symposium: unifying knowledge for sustainability in the Western hemisphere: September 20-24, 2004, Denver, Colorado: Proceedings RMRS-P-42CD, U.S. Department of Agriculture, Forest Service, Rocky Mountain Research Station, Fort Collins, Colorado, p. 238-241.

Sogge, M.K., Sferra, S.J., McCarthey, T.D., Williams, S.O., and Kus, B.E., 2003a, Distribution and characteristics of Southwestern Willow Flycatcher breeding sites and territories: Studies in Avian Biology, v. 26, p. 5-11.

Sogge, M.K., Sferra, S.J., and Paxton, E.H., 2008, Saltcedar as habitat for birds-Implications to riparian restoration in the Southwest: Restoration Ecology, v. 16, p. 146-154.
Sogge, M.K., Tibbitts, T.J., and Petterson, J., 1997a, Status and breeding ecology of the Southwestern Willow Flycatcher in the Grand Canyon: Western Birds, v. 28, p. 142-157.

Sogge, M.K., Tibbitts, T.J., van Riper, C., and May, T., 1995, Status of the Southwestern Willow Flycatcher along the Colorado River in Grand Canyon National Park-1995, Summary report: National Biological Service Colorado Plateau Research Station/Northern Arizona University, 26 p.

Spencer, J.A., Sferra, S.J., Corman, T.E., Rourke, J.W., and Sumner, M.W., 1996, Arizona Partners in Flight 1995 Southwestern Willow Flycatcher survey: Nongame and Endangered Wildlife Program Technical Report 79, Arizona Game and Fish Department, Phoenix, Arizona, 46 p.

State of Arizona, 1990, Final report and recommendations of the Governor's riparian habitat task force, Executive Order 89-16: Streams and riparian resources, Phoenix, Arizona, October 1990, 28 p.

Stein, R.C., 1963, Isolating mechanisms between populations of Traill's Flycatchers: Proceedings of the American Philosophical Society, v. 107, no. 1, p. 21-50.

Stoleson, S.H., and Finch, D.M., 2003, Microhabitat use by breeding Southwestern Willow Flycatchers on the Gila River, NM: Studies in Avian Biology, v. 26, p. 91-95.

Stoleson, S.H., Whitfield, M.J., and Sogge, M.K., 2000, Chapter 8: Demographic characteristics and population modeling, in Finch D.M., and Stoleson, S.H., eds., Status, ecology, and conservation of the Southwestern Willow Flycatcher: U.S. Forest Service Rocky Mountain Research Station General Technical Report-60, p. 84-94.

Tibbitts, T.J., Sogge, M.K., and Sferra, S.J., 1994, A survey protocol for the Southwestern Willow Flycatcher (Empidonax traillii extimus): National Park Service Technical Report NPS/NAUCPRS/NRTR-94/04.

Unitt, P., 1987, Empidonax traillii extimus: an endangered subspecies: Western Birds, v. 18, no. 3, p. 137-162.

U.S. Fish and Wildlife Service, 1991, Notice of review: animal candidate review for listing as endangered or threatened species, November 21, 1991: Federal Register 56:58804-58836.

U.S. Fish and Wildlife Service, 1993, Proposal to list the Southwestern Willow Flycatcher as an endangered species and to designate critical habitat, July 23, 1993: Federal Register 58:39495-39522.

U.S. Fish and Wildlife Service, 1995, Final Rule Determining Endangered Status for the Southwestern Willow Flycatcher: Federal Register 60:10694 (February 27, 1995). 
U.S. Fish and Wildlife Service, 1997, Final determination of critical habitat for the Southwestern Willow Flycatcher (Empidonax traillii extimus): Federal Register 62(140):39129-39147.

U.S. Fish and Wildlife Service, 2002, Southwestern Willow Flycatcher (Empidonax traillii extimus) final recovery plan: U.S. Fish and Wildlife Service, Albuquerque, New Mexico.

U.S. Fish and Wildlife Service, 2005, Designation of critical habitat for the Southwestern Willow Flycatcher (Empidonax traillii extimus), Final Rule: Federal Register 70:6088661009 (October 19, 2005).

Utah Division of Wildlife Resources, 1997, Utah Sensitive Species List - March 1997: Utah Division of Wildlife Resources, Salt Lake City, Utah, 28 p.

Whitfield, M.J., 1990, Willow Flycatcher reproductive response to brown-headed cowbird parasitism: Chico, California, California State University, Masters theses, 25 p.

Whitfield, M.J., and Enos, K., 1996, A Brown-headed Cowbird control program and monitoring for the Southwestern Willow Flycatcher, South Fork Kern River, California, 1996: Report to the U.S. Army Corps of Engineers, Sacramento District and the California Department of Fish and Game.
Whitfield, M.J., and Sogge, M.K., 1999, Range-wide impacts of Brown-headed Cowbird parasitism on the Southwestern Willow Flycatcher (Empidonax traillii extimus), 1999: Studies in Avian Biology, v. 18, p. 182-190.

Whitfield, M.J., and Strong, C.M., 1995, A Brown-headed Cowbird control program and monitoring for the Southwestern Willow Flycatcher, South Fork Kern River, California: California Department of Fish and Game, Bird and Mammal Conservation Program Report 95-4, Sacramento, California, 17 p.

Wiesenborn, W.D., and Heydon, S.L., 2007, Diet of Southwestern Willow Flycatcher compared among breeding populations in different habitats: Wilson Journal of Ornithology, v. 119, p. 547-557.

Wilbur, S.R., 1987, Birds of Baja California: Berkeley, California, University of California Press.

Yard, H.K., and Brown, B.T., 1999, Willow Flycatcher nest resuse in Arizona: Journal of Field Ornithology, v. 70, p. 211-213.

Yard, H.K., and Brown, B.T., 2003, Singing behavior of the Southwestern Willow Flycatchers in Arizona: Studies in Avian Biology, v. 26, p. 125-130. 


\section{Appendix 1. Willow Flycatcher Survey and Detection Form}

Always check the U.S. Fish and Wildlife Service Arizona Ecological Services Field Office web site (http://www.fws.gov/ southwest/es/arizona/) for the most up-to-date version.

Willow Flycatcher (WIFL) Survey and Detection Form (revised April 2010)

Site Name

State County USGS Quad Name Elevation (meters)

Creek, River, Wetland, or Lake Name

Is copy of USG S map marked with survey area and WIF L sightings attached (as required)?

Yes $\quad$ No

Survey Coordinates: Start: E

$\mathrm{N}$

UTM Datum

(See instructions)

Stop: E UTM Zone

If survey coordinates changed between visits, enter coordinates for each survey in comments section on back of this page. $* * \mathrm{~F}$ ill in additional site information on back of this page **

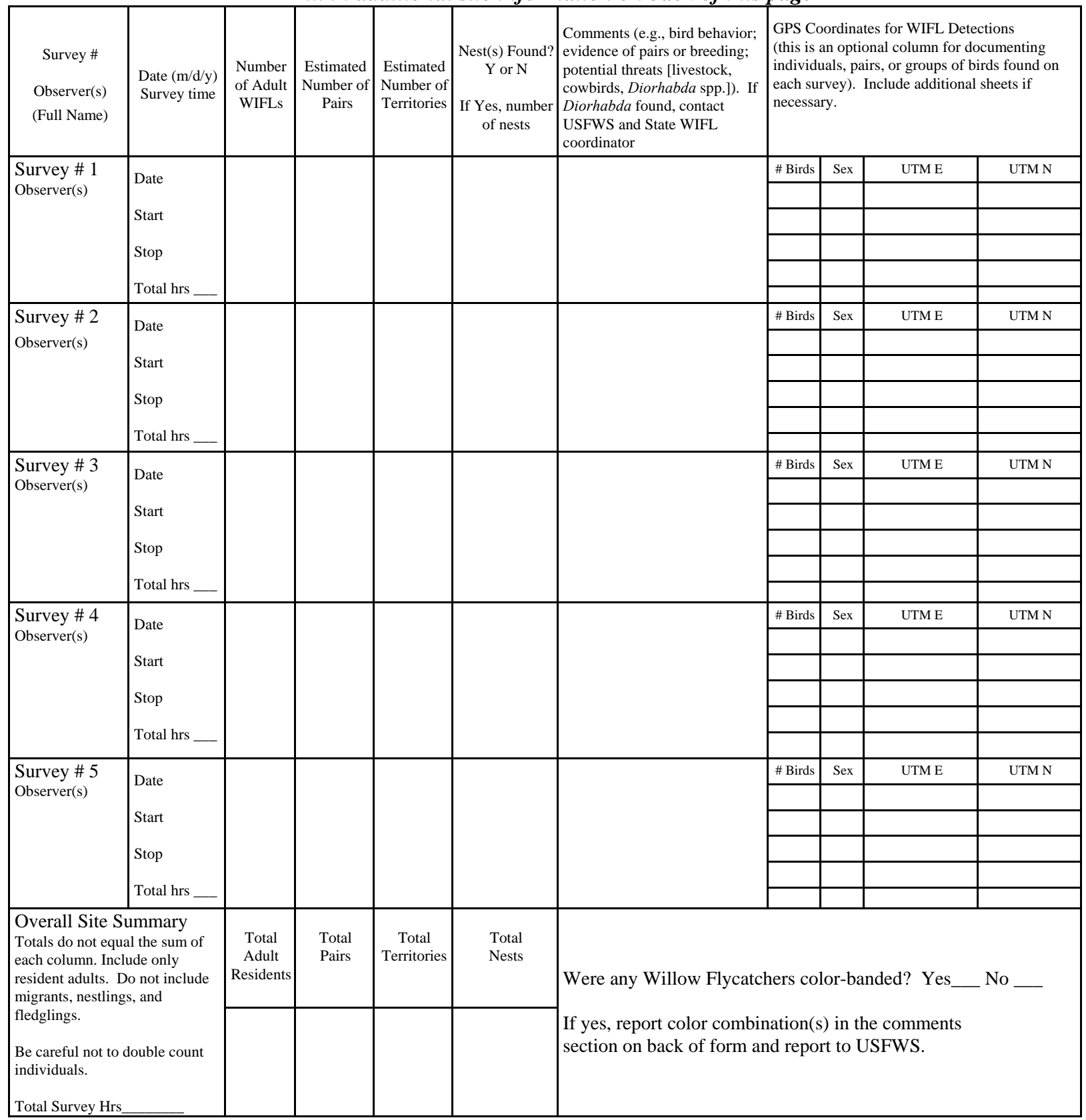

Reporting Individual

US Fish and Wildlife Service Permit \#

Date Report Completed

State Wildlife Agency Permit \#

Submit form to USF WS and State Wildlife Agency by September $1^{\text {st }}$. Retain a copy for your records. 


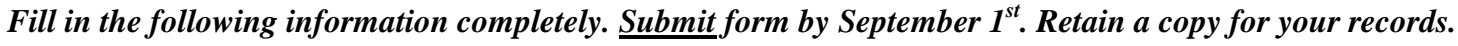

Reporting Individual

Affiliation

Site Name
Phone \#

E-mail

Date Report Completed

Did you verify that this site name is consistent with that used in previous years? Yes

If site name is different, what name(s) was used in the past?

If site was surveyed last year, did you survey the same general area this year? Y Yes __ No __ If no, summarize below.

Did you survey the same general area during each visit to this site this year? Yes

Yes $\_$No

If no, summarize below.

Management Authority for Survey Area : $\quad$ Federal___ Municipal/County ___ State ___ Tribal ___ Private ___ Name of Management Entity or Owner (e.g., Tonto National Forest)

Length of area surveyed: (meters)

Vegetation Characteristics: Mark the category that best describes the predominant tree/shrub foliar layer at this site (check one):

Native broadleaf plants (entirely or almost entirely, > 90\% native, includes high-elevation willow)

Mixed native and exotic plants (mostly native, 50 - 90\% native)

Mixed native and exotic plants (mostly exotic, 50 - 90\% exotic)

Exotic/introduced plants (entirely or almost entirely, > 90\% exotic)

Identify the 2-3 predominant tree/shrub species in order of dominance. Use scientific name.

Average height of canopy (Do not include a range):

(meters)

Attach copy of USGS quad/topographical map (REQUIRED) of survey area, outlining survey site and location of WIFL detections. Attach sketch or aerial photo showing site location, patch shape, survey route, location of any WIFLs or WIFL nests detected. Attach photos of the interior of the patch, exterior of the patch, and overall site; describe any unique habitat features.

Comments (attach additional sheets if necessary)

Territory Summary Table. Provide the following information for each verified territory at your site.

\begin{tabular}{|l|l|l|l|l|l|l|}
\hline $\begin{array}{c}\text { Territory } \\
\text { Number }\end{array}$ & $\begin{array}{c}\text { All Dates } \\
\text { Detected }\end{array}$ & UTM N & UTM E & $\begin{array}{c}\text { Pair } \\
\text { Confirmed? } \\
\text { Y or N }\end{array}$ & $\begin{array}{c}\text { Nest } \\
\text { Found? } \\
\text { Y or N }\end{array}$ & $\begin{array}{c}\text { Description of How You Confirmed } \\
\text { Territory and Breeding Status } \\
\text { (e.g., vocalization type, pair interactions, } \\
\text { nesting attempts, behavior) }\end{array}$ \\
\hline & & & & & & \\
\hline & & & & & & \\
\hline & & & & & & \\
\hline
\end{tabular}

Attach additional sheets if necessary 


\section{Appendix 2. Willow Flycatcher Survey Continuation Sheet / Territory Summary Table}

Always check the U.S. Fish and Wildlife Service Arizona Ecological Services Field Office web site (http://www.fws.gov/ southwest/es/arizona/) for the most up-to-date version.

Willow Flycatcher Survey Continuation Sheet

(For reporting additional detections and territories; append to Survey and Detection form)

Reporting Individual

Affiliation

Site Name
Phone \#

E-mail

Date Report Completed

\begin{tabular}{|l|l|l|l|c|c|c|}
\hline $\begin{array}{c}\text { Territory } \\
\text { Number }\end{array}$ & $\begin{array}{c}\text { All Dates } \\
\text { Detected }\end{array}$ & UTM E & UTM N & $\begin{array}{c}\text { Pair } \\
\text { Confirmed? } \\
\text { Y or N }\end{array}$ & $\begin{array}{c}\text { Nest } \\
\text { Found? } \\
\text { Y or N }\end{array}$ & $\begin{array}{c}\text { Description of How You Confirmed Territory } \\
\text { and Breeding Status (e.g., vocalization type, pair } \\
\text { interactions, nesting attempts, behavior) }\end{array}$ \\
\hline & & & & & & \\
\hline & & & & & & \\
\hline & & & & & & \\
\hline & & & & & & \\
\hline & & & & & & \\
\hline & & & & & & \\
\hline
\end{tabular}

Comments 


\section{Appendix 3. Instructions for Completing the Willow Flycatcher Survey and Detection Form and the Survey Continuation Sheet}

These instructions are provided as guidance for completing the standard survey form. It is particularly important to provide the correct type and format of information for each field. Complete and submit your survey forms to both the appropriate State Willow Flycatcher coordinator and the U.S. Fish and Wildlife Service (USFWS) by September 1 of the survey year. You also may complete forms digitally (Microsoft ${ }^{\circledR}$ Word or Excel) and submit them via email with attached or embedded topographic maps and photographs.

\section{Page 1 of Survey Form}

Site Name. Standardized site names are provided by the flycatcher survey coordinators for each State and should be consistent with the naming of other sites that might be in the area. If the site is new, work with your State or USFWS flycatcher coordinator to determine suitable site names before the beginning of the survey season. If the site was previously surveyed, use the site name from previous years (which can be obtained from the State or USFWS flycatcher coordinator). If you are uncertain if the site was previously surveyed, contact your State or USFWS flycatcher coordinator.

USGS Quad Name. Provide the full quad name, as shown on the appropriate standard 7.5-minute topographic maps.

Creek, River, Wetland, or Lake Name. Give the name of the riparian feature, such as the lake or watercourse, where the survey is being conducted.

Survey Coordinates. Provide the start and end points of the survey, which will indicate the linear, straight-line extent of survey area, based on Universal Transverse Mercator coordinates (UTMs). California surveyors only: provide latitude/longitude geographic coordinates instead of UTMs in the UTM fields and identify them as such. If the start and end points of the survey changed significantly among visits, enter separate coordinates for each survey in the comments section on the back of the survey sheet. Note that we do not need the coordinates for the detailed path taken by the surveyor(s).

Datum. Indicate the datum in which the coordinates are expressed: NAD27, WGS84, or NAD83. The datum can be found in the settings of most GPS units. Note that Arizona prefers NAD27 and New Mexico prefers NAD83.

Zone. Provide the appropriate UTM zone for the site, which is displayed along with the coordinates by most GPS units. Zones for California are 10, 11, or 12 . The zone for Arizona is 12 . Zones for New Mexico are 12 or 13.

Survey \#. Survey $1-5$. See the protocol for an explanation of the number of required visits for each survey period. Note: A survey is defined as a complete protocol-based survey that occurs over no more than 1 day. If a site is so large as to require more than a single day to survey, consider splitting the site into multiple subsites and use separate survey forms for each. Casual site visits, pre-season or supplemental visits, or follow-up visits to check on the status of a territory should not be listed in this column, but should be documented in the Comments section on page 2 or in the survey continuation sheet.
Date. Indicate the date that the survey was conducted, using the format $\mathrm{mm} / \mathrm{dd} / \mathrm{yyyy}$.

Start and Stop. Start and stop time of the survey, given in 24-hour format (e.g., 1600 hours rather than 4:00 p.m.).

Total hours. The duration of time (in hours) spent surveying the site, rounded to the nearest tenth (0.1) hour. For single-observer surveys, or when multiple observers stay together throughout the survey, total the number of hours from survey start to end. If two or more observers surveyed sections of the site concurrently and independently, sum the number of hours each observer spent surveying the site.

Number of Adult WIFLs. The total number of individual adult Willow Flycatchers detected during this particular survey. Do not count nestlings or recently fledged birds.

Number of Pairs. The number of breeding pairs. Do not assume that any bird is paired; designation of birds as paired should be based only on direct evidence of breeding behaviors described in the protocol. If there is strong evidence that the detected bird is unpaired, enter " 0 ". If it is unknown whether a territorial bird is paired, enter “-”. Note that the estimated number of pairs can change over the course of a season.

Number of Territories. Provide your best estimate of the number of territories, defined as a discrete area defended by a resident single bird or pair. This is usually evidenced by the presence of a singing male, and possibly one or more mates. Note that the estimated number of territories may change over the course of a season.

Nest(s) Found? Yes or No. If yes, indicate the number of nests. Renests are included in this total.

Comments about this survey. Describe bird behavior, evidence of pairs or breeding, evidence of nest building, evidence of nestlings/fledglings, nesting, vocalizations (e.g., interaction twitter calls, whitts, britts, wheeos, fitz-bews/countersinging), potential threats (e.g., livestock, cowbirds, saltcedar leaf beetles [Diorhabda spp.] etc.). If Diorhabda beetles are observed, contact your USFWS and State flycatcher coordinator immediately. Please be aware that permits are needed for nest monitoring.

GPS Coordinates for WIFL Detections. Provide the number of birds (e.g., unpaired, paired, or groups of birds) and corresponding UTMs. If known, provide the sex of individuals.

Overall Site Summary. For each of these columns, provide your best estimate of the overall total for the season. Do not simply total the numbers in each column. In some cases where consistent numbers were detected on each survey, the overall summary is easy to determine. In cases where numbers varied substantially among the different surveys, use professional judgment and logic to estimate the most likely number of adults, pairs, and territories that were consistently present. Be careful not to double count individuals. Record only territorial adult Southwestern Willow Flycatchers, do not include migrants, nestlings, or fledglings in the overall summary. In complex cases, consult with your State or USFWS flycatcher coordinator. 
Total Survey Hours. The sum of all hours spent surveying the site.

Were any WIFLs color-banded? Circle or highlight "Yes" or "No". If yes, report the sighting and color combination (if known) in the comments section on back of form, and contact your USFWS coordinator within 48 hours after returning from the survey. Note that identifying colors of bands is difficult and might require follow-up visits by experienced surveyors.

Reporting Individual. Indicate the full first and last name of the reporting individual.

Date Report Completed. Provide the date the form was completed in mm/dd/yyyy format.

U.S. Fish and Wildlife Service Permit \#. List the full number of the required federal permit under which the survey was completed.

State Wildlife Agency Permit \#. If a State permit is required by the State in which the survey was completed, provide the full number of the State permit. State permits are required for Arizona and California. State permits are recommended for New Mexico.

\section{Page 2 of Survey Form}

Affiliation. Provide the full name of the agency or other affiliation (which is usually the employer) of the reporting individual.

Phone Number. Self-explanatory; include the area code.

E-mail. Self-explanatory.

Was this site surveyed in a previous year? Indicate "Yes", "No", or "Unknown."

Did you verify that this site name is consistent with that used in previous years? Indicate "Yes" or "No". This can be determined by checking survey forms from previous years or consulting with agency flycatcher coordinators.

If site name is different, what name(s) was used in the past? Enter the full site name that was used in previous years.

If site was surveyed last year, did you survey the same general area this year? Indicate "Yes" or "No". If no, indicate the reason and how the survey varied in the Comments section.

Did you survey the same general area during each visit to this site this year? If no, indicate the reason in the Comments section and delineate the differing route of each survey on the topographical map.

Management Authority for Survey Area. Mark the appropriate management authority.

Name of Management Entity or Owner (e.g., Tonto National Forest). Provide the name of the organization or person(s) responsible for management of the survey site.
Length of area surveyed. Estimate the linear straight-line distance of the length of the area surveyed, in kilometers. This is not an estimate of the total distance walked throughout the survey site. Do not provide a range of distances.

Vegetation Characteristics: Mark only one of the categories that best describes the predominant tree/shrub foliar layer at the site.

Native broadleaf habitat is composed of entirely or almost entirely (i.e., > 90\%) native broadleaf plants.

Mostly native habitat is composed of 50-90\% native plants with some (i.e., 10-50\%) non-native plants.

Mostly exotic habitat is composed of 50-90\% non-native plants with some (i.e., 10-50\%) native plants.

Exotic/introduced habitat is composed entirely or almost entirely (i.e., > 90\%) of non-native plants.

Identify the 2-3 predominant tree/shrub species in order of dominance. Identify by scientific name.

Average height of canopy. Provide the best estimate of the average height of the top of the canopy throughout the patch. Although canopy height can vary, give only a single (not a range) overall height estimate.

Attach the following: (1) copy of USGS quad/topographical map (REQUIRED) of survey area, outlining survey site and location of WIFL detections; (2) sketch or aerial photo showing site location, patch shape, survey route, location of any detected WIFLs or their nests; (3) photos of the interior of the patch, exterior of the patch, and overall site. Describe any unique habitat features in Comments. Include the flycatcher territory number and GPS location. You also may include a compact disc of photographs.

Comments. Include any information that supports estimates of total territory numbers and breeding status. You may provide additional information on bird behavior, banded birds, evidence of pairs or breeding, nesting, potential threats (e.g., livestock, cowbirds, saltcedar leaf beetles [Diorhabda spp.] etc.), and changes in survey length and route throughout the season. Attach additional pages or use the continuation sheet if needed.

Table. If Willow Flycatchers are detected, complete the table at the bottom of the form. Identify flycatchers by territory number and include the dates detected, UTMs, whether or not pairs were detected, and whether or not nests were located. Also describe the observation. For example, the surveyor might have observed and heard a bird fitz-bew from an exposed perch, heard and observed two birds interacting and eliciting a twitter call, heard a bird fitz-bew while observing another carrying nesting material, heard birds from territory 1 and 2 countersinging, etc. This information provides supporting information for territory and breeding status. Use the continuation sheet if needed. 


\section{Appendix 4. Example of a Completed Willow Flycatcher Survey and Detection Form (with map)}

Willow Flycatcher (WIFL) Survey and Detection Form (revised April, 2010)

Site Name: $\quad$ DL-08

State: New Mexico

County: Socorro

USGS Quad Name: $\quad$ Paraje Well $\quad$ Elevation: $\overline{1,356}$

(meters)

Creek, River, or Lake Name: $\quad$ Rio Grande

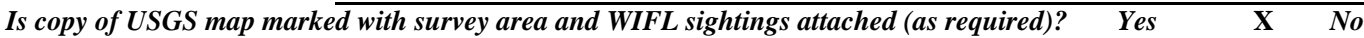

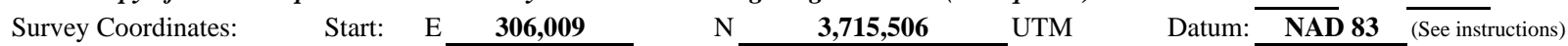

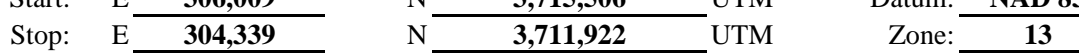

If survey coordinates changed between visits, enter coordinates for each survey in comments section on back of this page.

**Fill in additional site information on back of this page ${ }^{* *}$

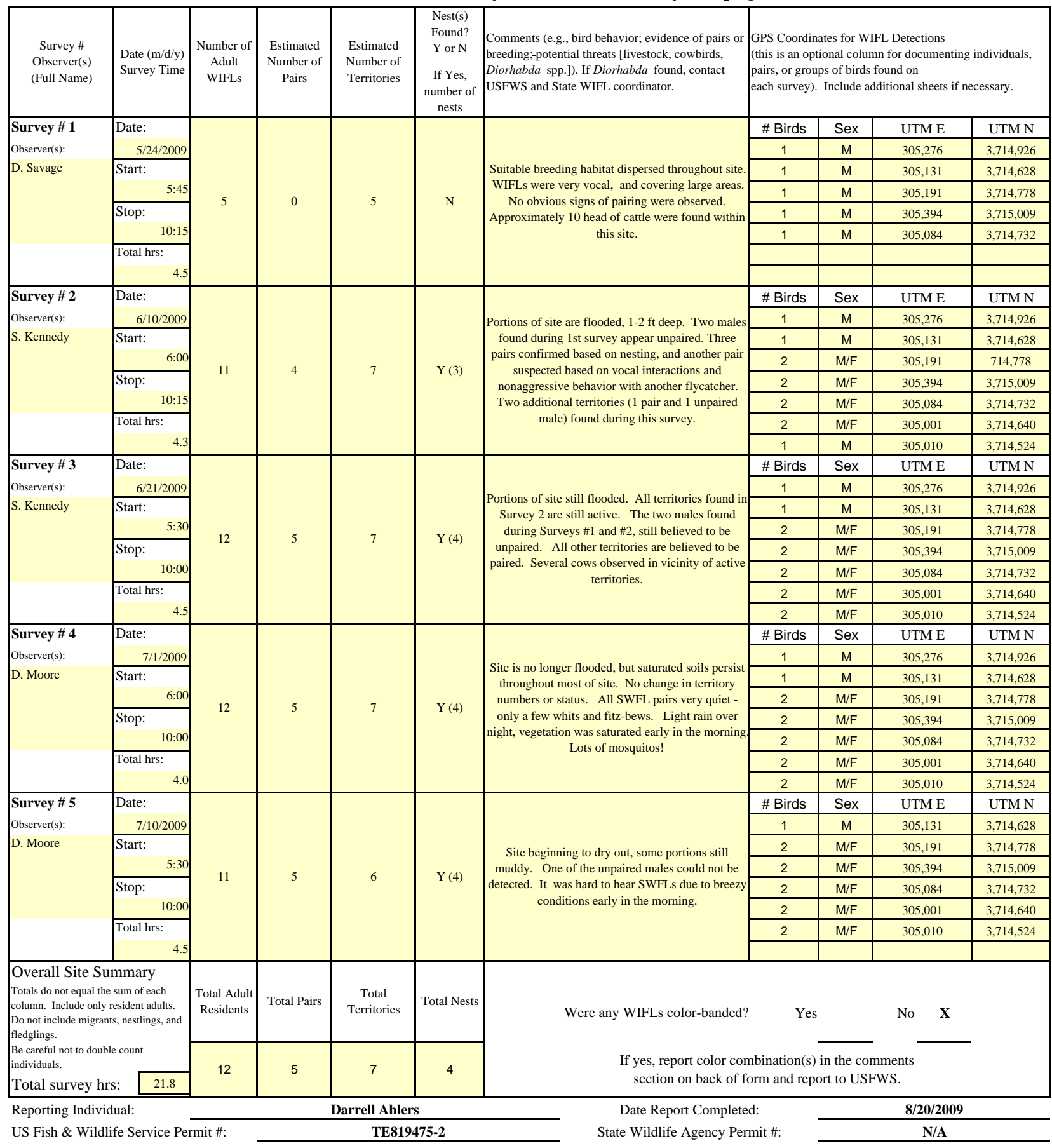

Submit form to USFWS and State Wildlife Agency by September 1st. Retain a copy for your records. 


\section{Fill in the following information completely. Submit form by September $1^{\text {st }}$. Retain a copy for your records.}

Reporting Individual

Affiliation

Site Name
Darrell Ahlers

Bureau of Reclamation

DL-08
Phone \#

E-mail

Date report Completed

(303) 445-2233

dahlers@usbr.gov $8 / 20 / 2009$ Was this site surveyed in a previous year? Yes__ _ _ No___ Unknown_ Did you verify that this site name is consistent with that used in previous yrs? $\quad$ Yes _ $\quad \mathbf{x}$ If name is different, what name(s) was used in the past? Not applicable

If site was surveyed last year, did you survey the same general area this year? $\quad$ Yes $\quad$ X $\quad$ X Did you survey the same general area during each visit to this site this year? Yes

$\begin{array}{ll}\text { No } & \text { If no, summarize below. } \\ \text { No } & \text { If no, summarize below. }\end{array}$

Management Authority for Survey Area:

Federal _ X Municipal/County

Name of Management Entity or Owner (e.g., Tonto National Forest)

State

Length of area surveyed: 2.5 $(\mathrm{km})$

Vegetation Characteristics: Check (only one) category that best describes the predominant tree/shrub foliar layer at this site:

Native broadleaf plants (entirely or almost entirely, > 90\% native)

$\mathrm{X}$

Mixed native and exotic plants (mostly native, 50 - 90\% native)

Mixed native and exotic plants (mostly exotic, 50 - 90\% exotic)

Exotic/introduced plants (entirely or almost entirely, > 90\% exotic)

Identify the 2-3 predominant tree/shrub species in order of dominance. Use scientific name.

Salix Gooddingii, Populus spp., Tamarix spp.

Average height of canopy (Do not include a range):

6

(meters)

Attach the following: 1) copy of USGS quad/topographical map (REQUIRED) of survey area, outlining survey site and location of WIFL detections;

2) sketch or aerial photo showing site location, patch shape, survey route, location of any detected WIFLs or their nests;

3) photos of the interior of the patch, exterior of the patch, and overall site. Describe any unique habitat features in Comments.

Comments (such as start and end coordinates of survey area if changed among surveys, supplemental visits to sites, unique habitat features.

Attach additional sheets if necessary.

Great habitat with saturated or flooded soils throughout most of the site on 1st survey. Site began to dry by the end of the breeding season. SWFL territories are dominated by Gooddings willow, however Tamarix spp. tends to be increasing in density compared to previous years. Site is supported by flows from the Low Flow Conveyance Channel.

Territory Summary Table. Provide the following information for each verified territory at your site.

\begin{tabular}{|c|c|c|c|c|c|c|}
\hline Territory Number & All Dates Detected & UTM E & UTM N & $\begin{array}{c}\text { Pair } \\
\text { Confirmed? } \\
\text { Y or } \mathrm{N}\end{array}$ & $\begin{array}{l}\text { Nest Found? } \\
\text { Y or } \mathrm{N}\end{array}$ & $\begin{array}{c}\text { Description of How You Confirmed } \\
\text { Territory and Breeding Status } \\
\text { (e.g., vocalization type, pair interactions, } \\
\text { nesting attempts, behavior) }\end{array}$ \\
\hline 1 (Unpaired male) & $5 / 24,6 / 10,6 / 21,7 / 1$ & 305,276 & $3,714,926$ & $\mathrm{~N}$ & $\mathrm{~N}$ & $\begin{array}{c}\text { extended presence at site from } 5 / 24 \text { through } 7 / 1 \text {, no } \\
\text { evidence of pairing }\end{array}$ \\
\hline 2 (Unpaired male) & $5 / 24,6 / 10,6 / 21,7 / 1,7 / 10$ & 305,131 & $3,714,628$ & $\mathrm{~N}$ & $\mathrm{~N}$ & $\begin{array}{l}\text { extended presence at site from 5/24 through 7/10, } \\
\text { no evidence of pairing }\end{array}$ \\
\hline 3 (Pair) & $5 / 24,6 / 10,6 / 21,7 / 1,7 / 10$ & 305,191 & $3,714,778$ & $\mathrm{Y}$ & $\mathrm{Y}$ & $\begin{array}{c}\text { Pair confirmed based on vocalizations and } \\
\text { observation of unchallenged WIFL }\end{array}$ \\
\hline 4 (Pair w/nest) & $5 / 24,6 / 10,6 / 21,7 / 1,7 / 10$ & 305,394 & $3,715,009$ & $\mathrm{Y}$ & $\mathrm{Y}$ & Confirmed breeding status with nest \\
\hline 5 (Pair w/nest) & $5 / 24,6 / 10,6 / 21,7 / 1,7 / 10$ & 305,084 & $3,714,732$ & $\mathrm{Y}$ & $\mathrm{Y}$ & Confirmed breeding status with nest \\
\hline 6 (Pair w/nest) & $6 / 10,6 / 21,7 / 1,7 / 10$ & 305,001 & $3,714,640$ & $\mathrm{Y}$ & $\mathrm{Y}$ & Confirmed breeding status with nest \\
\hline 7 (Pair w/nest) & $6 / 10,6 / 21,7 / 1,7 / 10$ & 305,010 & $3,714,524$ & $\mathrm{Y}$ & $\mathrm{N}$ & Confirmed breeding status with nest \\
\hline
\end{tabular}

Attach additional sheets if necessary 


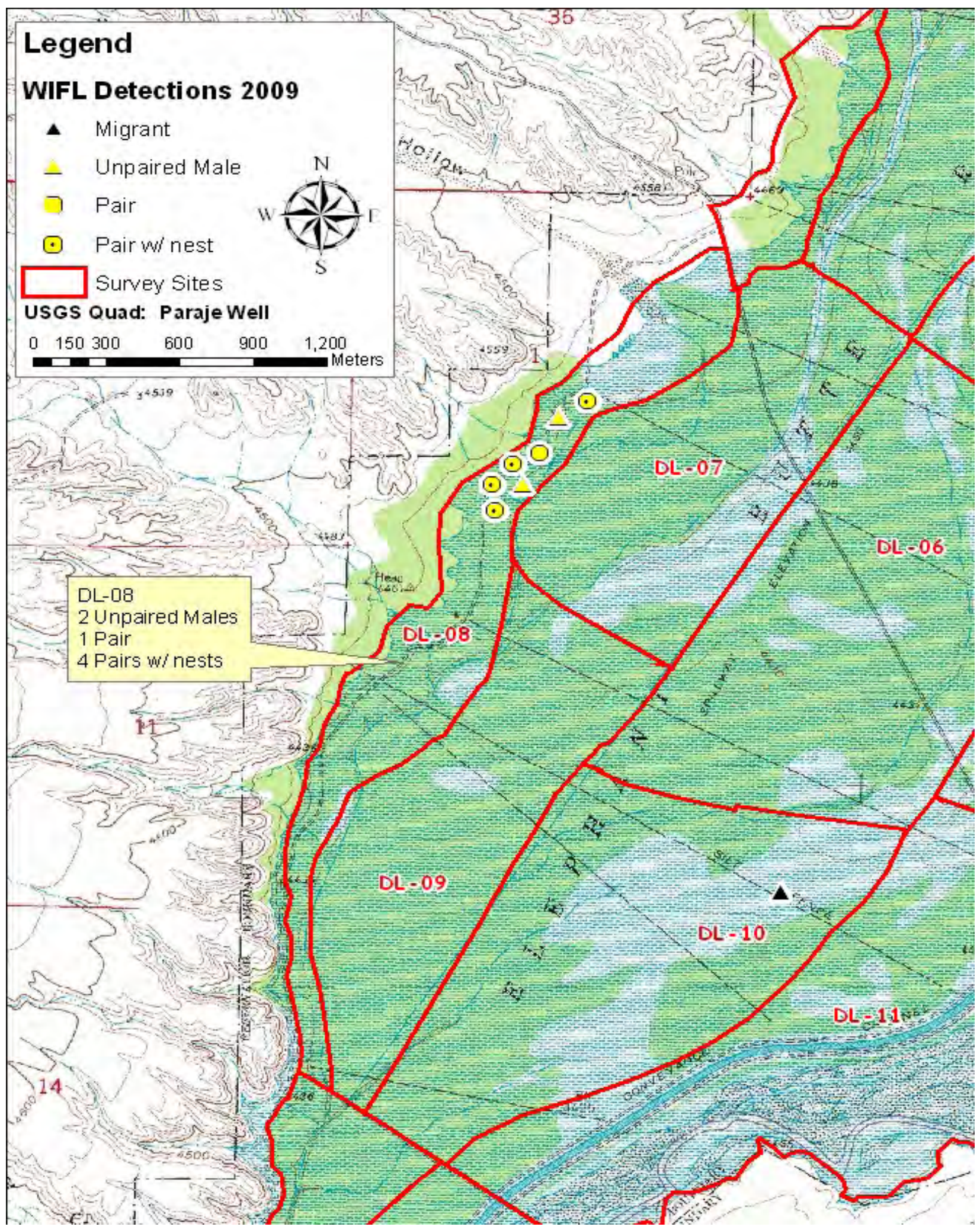


Publishing support provided by the U.S. Geological Survey Publishing Network, Tacoma Publishing Service Center

For more information concerning the research in this report, contact Mark Sogge

U.S. Geological Survey

2255 Gemini Drive,

Flagstaff, AZ 86001 


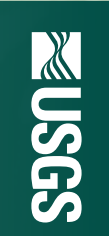

